\title{
Redwine or Pie-Crust Mode Forms in East Texas Caddo Ceramics and Comparisons with Sprocket-Rims of Southwest Arkansas
}

Mark Walters

Heritage Research Center, Stephen F. Austin State University

Tom Middlebrook

Heritage Research Center, Stephen F. Austin State University

Timothy K. Perttula

Heritage Research Center, Stephen F. Austin State University

Follow this and additional works at: https://scholarworks.sfasu.edu/ita

Part of the American Material Culture Commons, Archaeological Anthropology Commons, Environmental Studies Commons, Other American Studies Commons, Other Arts and Humanities Commons, Other History of Art, Architecture, and Archaeology Commons, and the United States History Commons

Tell us how this article helped you.

This Article is brought to you for free and open access by the Center for Regional Heritage Research at SFA ScholarWorks. It has been accepted for inclusion in Index of Texas Archaeology: Open Access Gray Literature from the Lone Star State by an authorized editor of SFA ScholarWorks. For more information, please contact cdsscholarworks@sfasu.edu. 


\section{Redwine or Pie-Crust Mode Forms in East Texas Caddo Ceramics and Comparisons with Sprocket-Rims of Southwest Arkansas}

\section{Creative Commons License}

\section{(c) (1) (8)}

This work is licensed under a Creative Commons Attribution-NonCommercial 4.0 International License 


\title{
REDWINE OR PIE-CRUST MOdE FORMS in EAST TEXas CADdo CERAMICS AND Comparisons WITH SPROCKET-RIMS OF SOUTHWEST ARKANSAS
}

\author{
Mark Walters \\ with contributions by \\ Tom Middlebrook and Timothy K. Perttula
}

\section{Introduction}

Caddo ceramics served many purposes, including cooking, storage, and the serving of foods and liquids. The various forms and shapes of these vessels were subject to the ideas of the potters themselves and the larger community of which they were a part. Products of human behavior reflect conscious and predictable actions that can be identified and measured in time and space. Artifacts are "embodiments of human behavior" (White 1959:232-233).

The various elements that make up an artifact are termed attributes. Certain attributes that reflect customary usage or current fashion are termed nodes. Irving Rouse describes a mode as "any standard, concept, or custom which governs the behavior of the artisans of a community, which they hand down from generation to generation over considerable distances" (Rouse 1960:109). The particular artifact that is the main focus of consideration in this article is a unique prehistoric Caddo ceramic rim mode defined as the Redwine or "pie-crust" mode. We also discuss the related Myers mode or "sprocket-rim" that is another particular form of rim identified in prehistoric Caddo sites.

We examine specific Caddo ceramic vessels from East Texas sites, almost all of which date to the Middle Caddo period (ca. A.D. 1200-1400), and in particular one unique attribute found on those vessels, to hopefully better understand prehistoric Caddo communities and their interaction. The Middle Caddo period in East Texas was dynamic in terms of the artistic ceramic artifacts characteristic of the period. Different but contemporaneous groups were experimenting with new forms of ceramic vessels as well as how they chose to decorate their vessels, as exemplified by the appearance of the engraved canebrake rattlesnake motif on fine ware vessels (Walters 2006:5-40). These vessel forms and designs became established patterns and through contact and interaction, movement of people, and/or the sharing and adoption of ideas, they spread to other groups. In the study of Caddo archeology, we are very fortunate that the Caddo potters left an extensive ceramic record that is very rich in its stylistic diversity. By studying the ties between different but contemporaneous groups of people through the similarities and differences in ceramic styles, attributes, modes, and techniques, we can arrive at a better understanding of how these diverse groups interacted with each other. It is becoming increasingly evident that ceramic vessels were widely traded amongst widelyspaced Caddo groups, and that some kinds of ceramic vessels (such as the Redwine mode vessels or other distinctive forms) were an important indication of the existence of exchange relationships, or special bonds and alliances, between groups. 


\section{Definition of the Redwine or Pie-crust and Myers Mode Rims}

The Redwine and Myers modes refer to the portion of a vessel designated as the rim or edge, border, or margin of the mouth or orifice of a vessel. The orifice is one of the three essential components, along with the base and body, of a ceramic vessel (Rice (1987:212-214). The orifice, or mouth opening, may be described in terms of two secondary form characteristics, the lip and the rim. The lip is described as the edge or margin of the orifice that is also the edge of the rim of a vessel, and as such is a part of the rim (e.g., a direct rim with a rounded lip). The rim is defined as "the area between the change of orientation of the lip (or margin) and the side or neck of the vessel” (Rice 1987:212-214; e.g., as with a carinated bowl). In certain vessel forms the distinction between the two is difficult to define, as in the case of a simple bowl with a direct rim.

The Redwine or pie-crust rim mode as a distinct form of rim treatment was first noted in the ceramics from the Redwine site (41SM193). Redwine is a Middle Caddo period habitation and mound site located in eastern Smith County, Texas (Walters and Haskins 1998).

The term "pie-crust" occurs earlier in the Caddo archeological literature in the Standridge site report (Early 1988:72), wherein Ann Early mentioned rims that had a "deeply notched piecrust-shaped lip." In an April, 2008, personal communication to Mark Walters, she stated that these particular rims were undulating and had lip notches, and the lip orientation was both vertical or conformable with the rim and projected horizontally. These Standridge site rims are different from rims with the Redwine rim mode.

What distinguishes the Redwine rim mode form as defined in this article is the rim's acute angle or change in orientation from the side of the vessel (Figure 1). It is this degree of articulation on certain vessels, almost all of them dating to the Middle Caddo period, that is so uncommon in other Caddo vessel forms. The Redwine mode of rim construction is unique in East Texas Caddo pottery as well as all of the Caddo area.

Most of the Redwine mode rims are at abrupt right angles to the vessel wall, although there are a few examples of angles that are both more and less than 90 degrees. The Redwine mode rims all have evenly spaced scalloped lobes (Figure 2), edges or lips, as the case may be. These differ from the triangular-shaped cogs or sprockets on the Myers mode rims that form an undulating, wave-like appearance (Figure 3).

The Myers mode rim form was identified on certain Myers Engraved vessels, a new pottery type identified during analysis of ceramics from the Middle Caddo Myers site (3M139) in southwestern Arkansas. John Miller (1986:97) described the rim treatment as: "cogged or sprocketed lips or rims which consisted of a series of triangular cogs which radiate outward at almost right angles to the rim." In certain instances, the short arm of the triangles appear to have cut edges to shape them, probably done when the vessel was in a leather-hard stage prior to firing.

The Redwine mode is primarily found on vessels from two small clusters of sites in East Texas (Figure 4). The largest cluster, consisting of 10 sites, is centered in the upper reaches of the Sabine River basin, primarily on the southern side of the basin. A smaller cluster of five sites with Redwine mode vessels is located in the Angelina River basin, centered on the Washington Square Mound site (41NA49) in the city of Nacogdoches, Texas. Vessels with the Myers rim mode are restricted mainly to a small number of sites in southwestern Arkansas (Figure 5), but examples are known from a few sites in East Texas (see below).

The distinction between the rounding and scalloped lobes of the Redwine mode and the undulations of the Myers' mode is definitive, and there are no known examples of both forms of rim treatment existing on a single vessel; there is one instance discussed below where examples of both forms of vessels occur in a single grave. The differences between these two modes was evidently a ceramic practice that Caddo potters went to great pains to keep separate. 


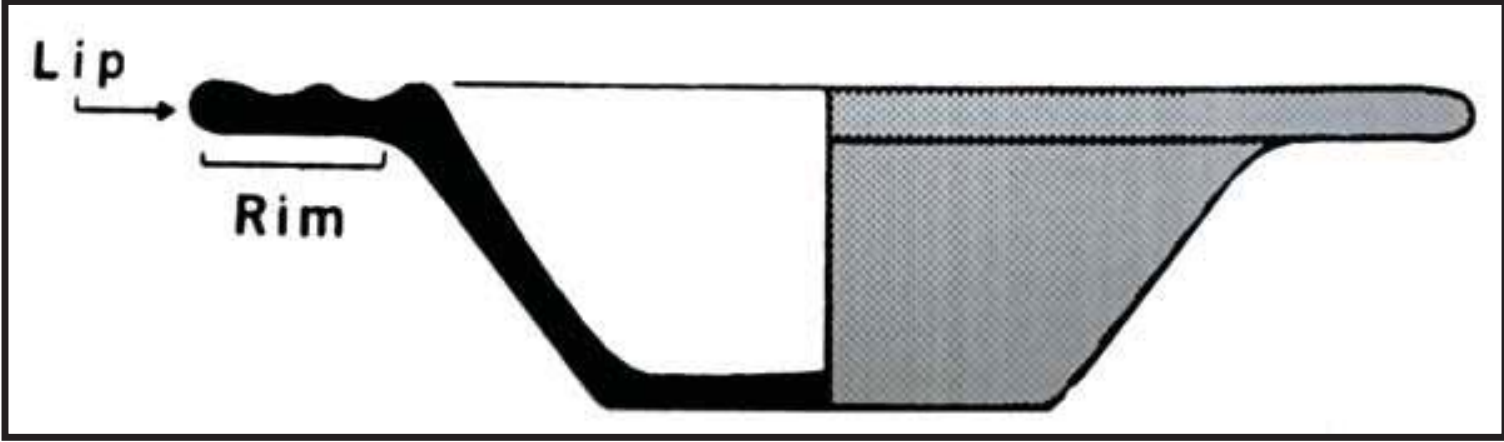

Figure 1. Example of articulated rim (Rice 1987:214 and Figure 7.3b).

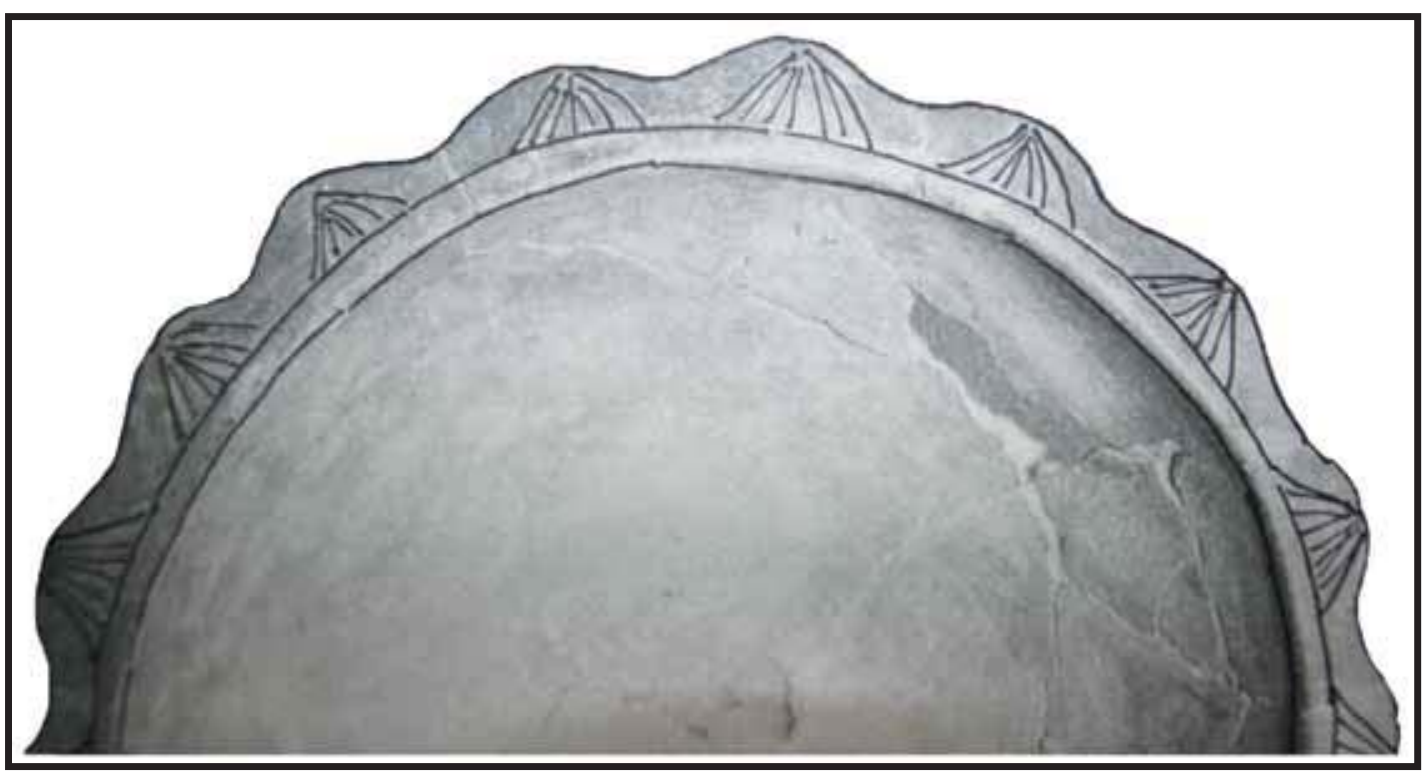

Figure 2. Redwine mode "pie-crust" rim.

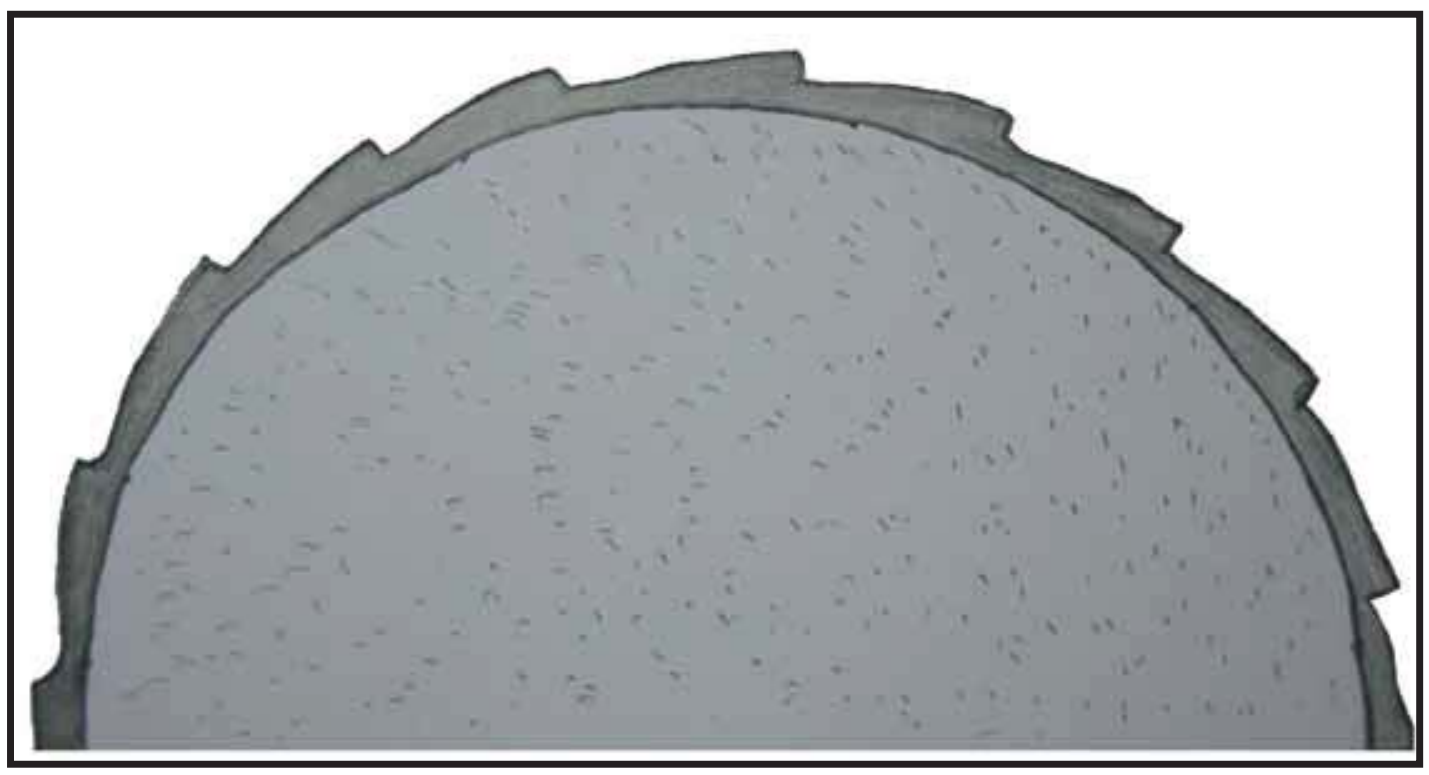

Figure 3. Myers mode "sprocket" rim. 


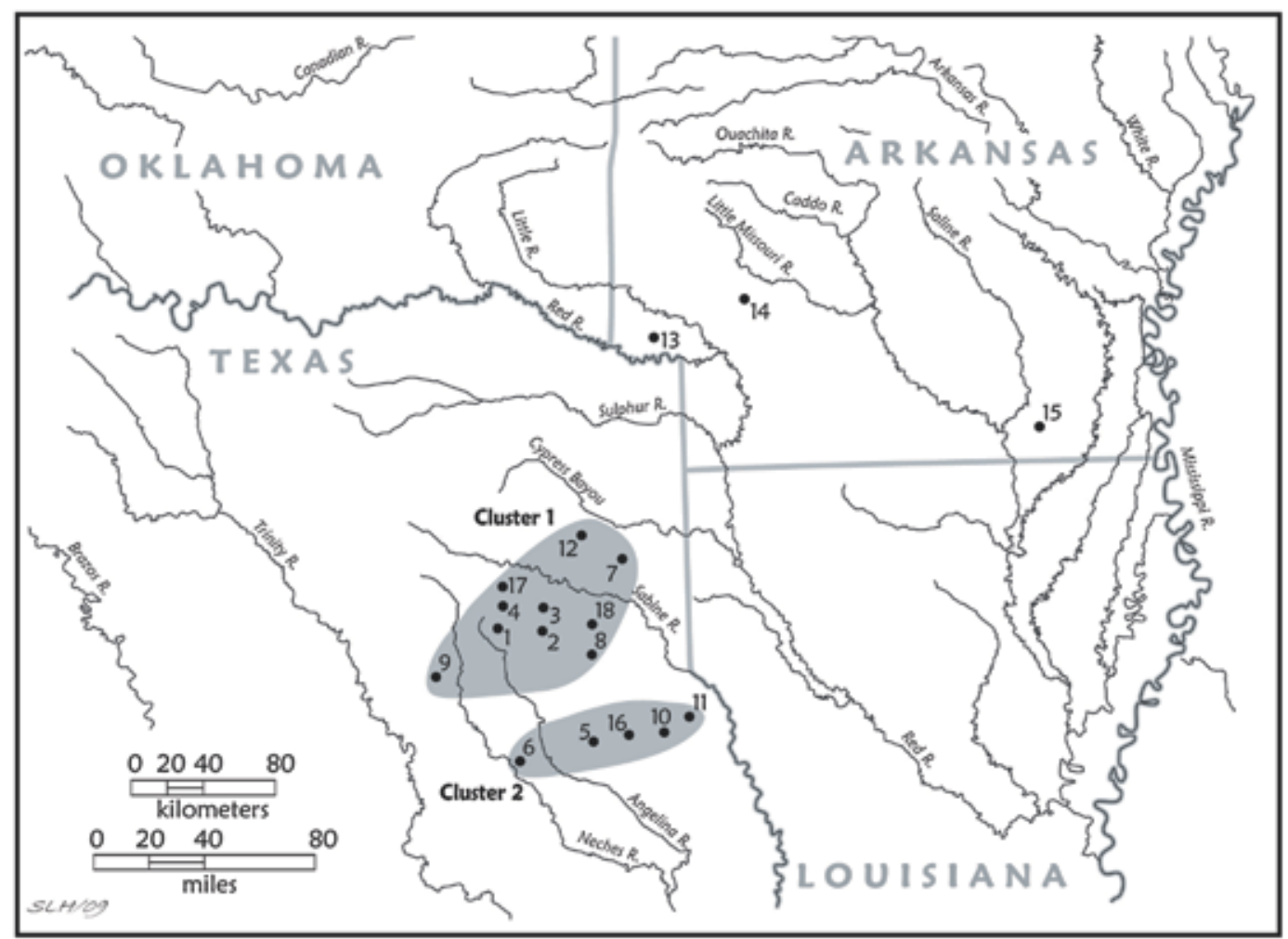

Figure 4. Distribution map of Redwine mode rim examples.

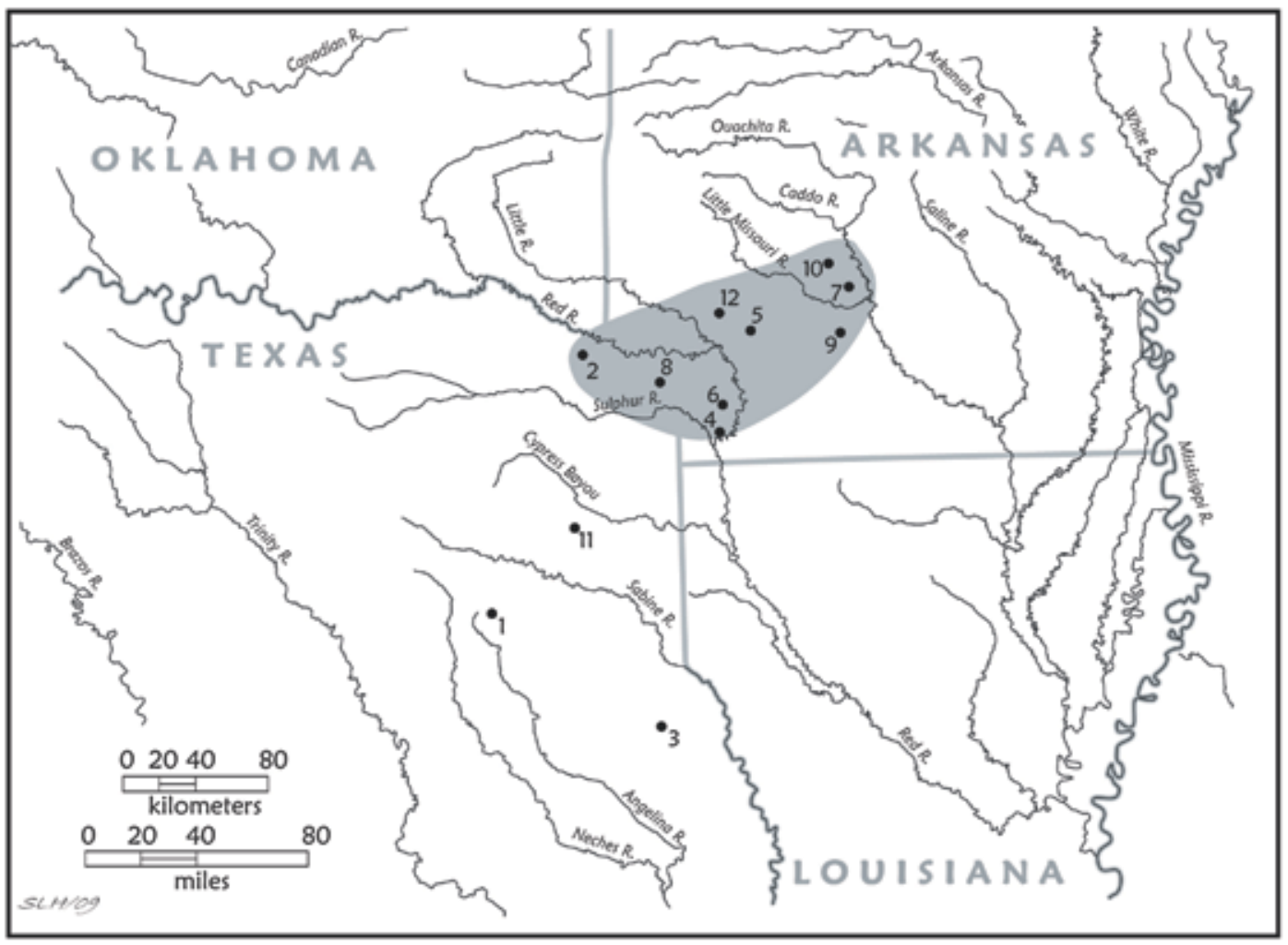

Figure 5. Distribution map of Myers mode rim examples. 


\section{Examples of the Redwine rim mode on ceramic vessels from East Texas Caddo sites:}

Table 1 lists known vessels with rim treatments that compare favorably with the Redwine mode rim. There are not many examples from any one site, and the numbers represented may have been skewed by the amount of archeological work done at any one site, or by the level of detail provided in published reports of particular vessels. If a Redwine rim mode vessel was available for study, a detailed form has been completed that provides various relevant attributes about the vessel, its form, size, temper/paste, firing conditions, wall thickness, and decoration.

Table 1. Sites with Redwine mode rims and number of known examples.

\begin{tabular}{llll}
\hline Site & No. & Site & No. \\
\hline 41 CE19 & 10 & 41 SM196 & 1 \\
41 SY45 & 10 & 41 HS718 & 1 \\
3LR46/50 & 9 & 41 RK276 & 1 \\
41 NA49 & 4 & 41 SY41 & 1 \\
41 SM193 & 4 & 3 HE35 & 1 \\
41 SM325 & 3 & 3SA154 & 1 \\
41 UR315 & 3 & 41 NA231 & 1 \\
41 SM223 & 2 & 41 SM198 & 1 \\
41 AN38 & 2 & *Fields site & 1 \\
GC 108** & 1 & & \\
\hline
\end{tabular}

${ }^{*}$ Not plotted; $* *$ no trinomial

\section{Cluster 1 Sites}

We have identified 19 sites across the Caddo area where there are vessels with the Redwine mode rim. These sites are discussed in the order of their spatial association with one another (see Figure 4), the presumption being that the closer different sites are located to one other, the more likely they are to be culturally associated. There are few absolute dates for these sites, but they apparently date to the Middle Caddo (A.D. 1200-1400) period.

Cluster 1, including the Redwine site, is the largest concentration of sites with vessels exhibiting the Redwine mode. Cluster 1 is comprised of eight sites in the upper reaches of the Sabine River drainage, one site (41AN38) on the Neches River, and one site (41UR315) in the Cypress Basin. Seven of the Sabine River sites occur on the south side of the Sabine River, on small neighboring drainages, and one site in Cluster 1 is located on the north side of the Sabine River.

\section{Redwine (41SM193)}

The Redwine site is a mid- $14^{\text {th }}$ century Middle Caddo habitation site with a single mound that covered a burned structure with an extended entrance (Walters and Haskins 1998). The Redwine mode rim is present on two whole vessels and two rim sherds from other vessels. 


\section{Vessel 1 (Walters and Haskins 1998:Figure 11i) (Figure 6)}

VESSEL FORM: Bowl with a Redwine mode rim. The angle of articulation is greater than 90 degrees and the rim in profile actually hangs down. The lip is scalloped, forming 17 rounded lobes that average $11.0 \mathrm{~mm}$ in thickness.

NON-PLASTICS: Grog and hematite

CORE COLOR: F (reduced firing but cooled in the open air)

INTERIOR SURFACE COLOR: dark yellowish-brown (10YR3/6)

EXTERIOR SURFACE COLOR: dark yellowish-brown (10YR3/6)

WALL THICKNESS: $5.4 \mathrm{~mm}$

INTERIOR SURFACE TREATMENT: Smoothed

EXTERIOR SURFACE TREATMENT: Burnished

HEIGHT: $7.5 \mathrm{~cm}$

ORIFICE DIAMETER: $20.5 \mathrm{~cm}$

BASE DIAMETER: $9.1 \mathrm{~cm}$

DECORATION: Engraved line circles the top of the articulated rim with cross-hatched engraved pendant triangles on the rim that are centered on top of each lobe. There is red pigment in the engraved lines.

TYPE: Untyped

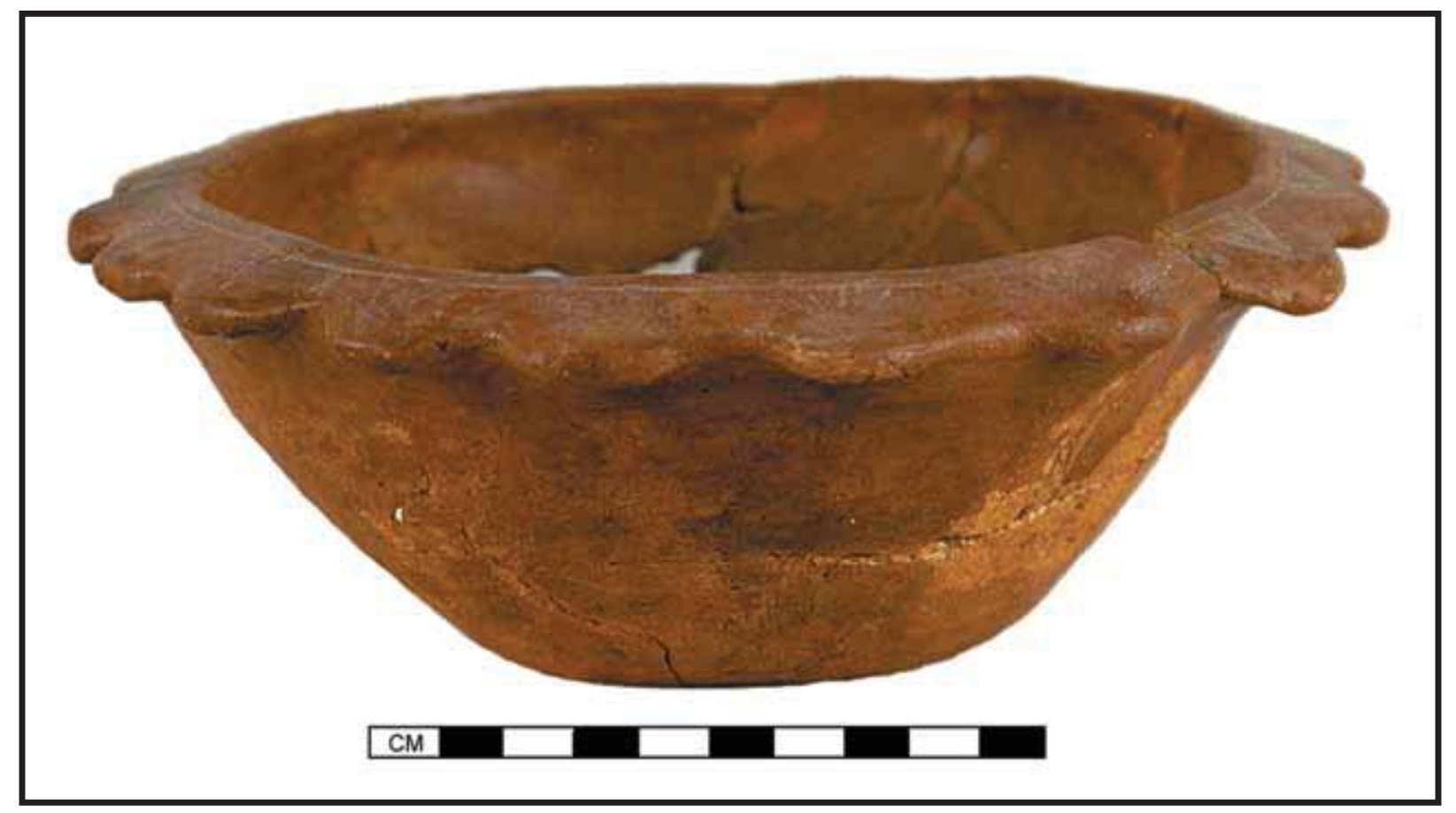

Figure 6. Bowl from the Redwine site (41SM193) with Redwine mode rim. 


\section{Vessel 2 (Walters and Haskins 1998:Figure 11c) (Figure 7)}

VESSEL FORM: Jar with the upper rim folded out at a right angle; the undulating lip has 10 rounded lobes. There are two strap handles on opposite sides of the rim. The rim has four evenly spaced peaks.

NON-PLASTICS: Grog

CORE COLOR: B (reduced firing and cooling)

EXTERIOR SURFACE COLOR: black (10YR2/1)

INTERIOR SURFACE COLOR: black (10YR2/1)

WALL THICKNESS: Not available

INTERIOR SURFACE TREATMENT: Smoothed and burnished near the top

EXTERIOR SURFACE TREATMENT: Burnished

HEIGHT: $7.0 \mathrm{~cm}$

ORIFICE DIAMETER: $7.5 \mathrm{~cm}$

BASE DIAMETER: $6.0 \mathrm{~cm}$

DECORATION: Engraved and excised scrolls and concentric circles on the vessel body of the vessel and on the strap handles. The rim is decorated with rectangular panels outlined by punctates and filled with parallel brushing. There is white pigment in the engraved lines.

TYPE: Washington Square Paneled or Nacogdoches Engraved, var. Redwine. This variety of Nacogdoches Engraved is newly defined in the region.

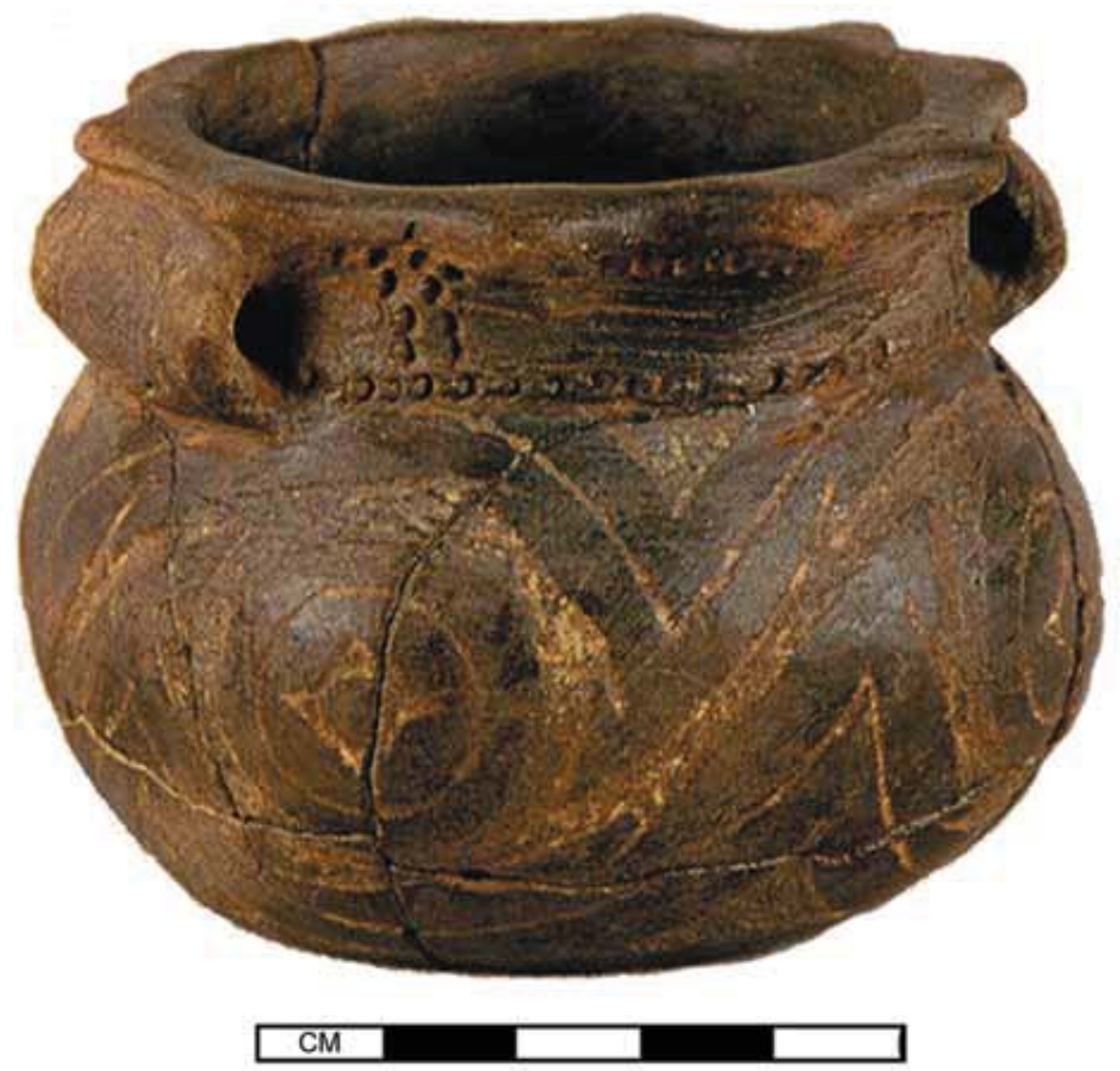

Figure 7. Jar with Redwine mode rim from the Redwine site. 


\section{Rim Sherd 1, surface}

VESSEL FORM: Bowl (similar to Vessel 1) with a Redwine mode rim. The rim sherd has a single lobe that is $10.0 \mathrm{~mm}$ thick.

NON-PLASTICS: Grog and hematite

CORE COLOR: F (reduced firing but cooled in the open air)

INTERIOR SURFACE COLOR: brown (7.5YR4/4)

EXTERIOR SURFACE COLOR: brown (7.5YR4/2)

WALL THICKNESS: $5.7 \mathrm{~mm}$

INTERIOR SURFACE TREATMENT: Burnished

EXTERIOR SURFACE TREATMENT: Burnished

DECORATION: None (but the surface is eroded)

\section{Rim Sherd 2, surface (Figure 8)}

VESSEL FORM: Bowl (similar to Vessel 1) with a Redwine mode rim. The rim sherd has two lobes that average $11.5 \mathrm{~mm}$ in thickness.

NON-PLASTICS: Grog and hematite

CORE COLOR: B (reduced)

INTERIOR SURFACE COLOR: brown (7.5YR4/3)

EXTERIOR SURFACE COLOR: brown (7.5YR5/4)

WALL THICKNESS: $5.0 \mathrm{~mm}$

INTERIOR SURFACE TREATMENT: Burnished

EXTERIOR SURFACE TREATMENT: Burnished

DECORATION: Engraved concentric semi-circles with hatched marks on the top of each lobe. There is a red pigment in the engraved lines.

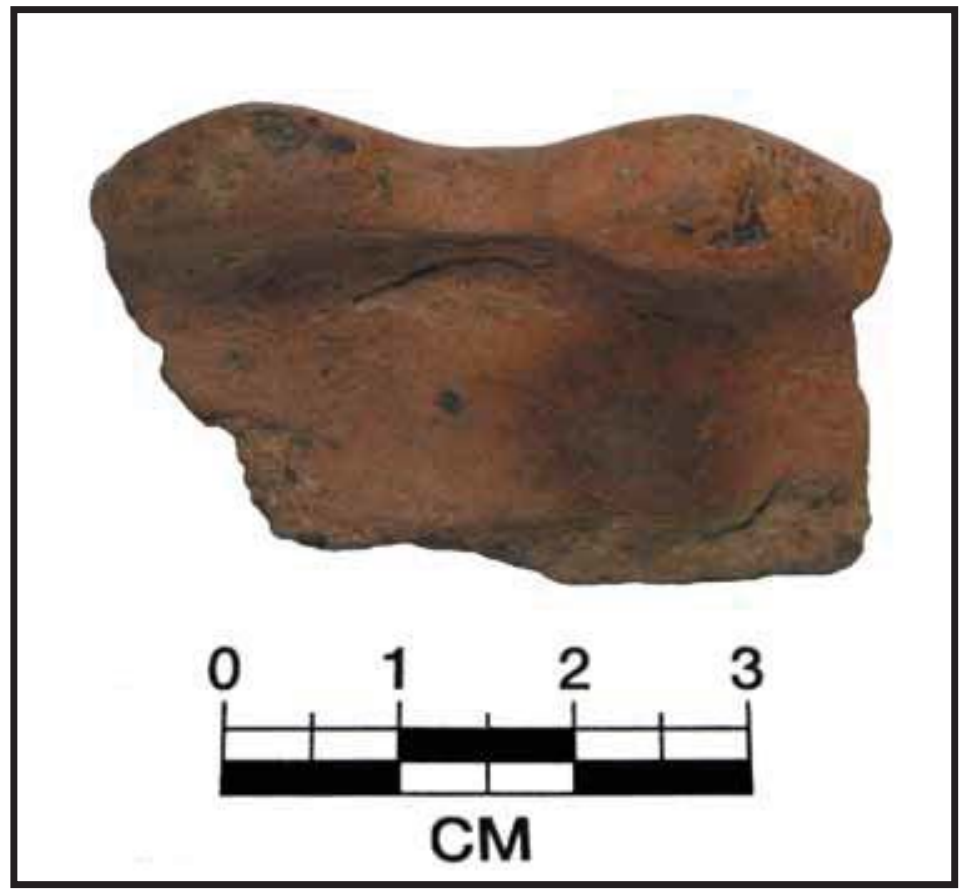

Figure 8. Redwine mode rim sherd from the Redwine site. 
41SM223 is 3 miles from the Redwine site and is in the same drainage. There are no radiocarbon dates from this site, but the range of artifacts recovered from three burials excavated here indicates that these interments occurred in Middle Caddo times. The two vessels from Burial 1 exhibit two different varieties of the Redwine mode (see discussion below). This combination also occurred in the same burial at Redwine, demonstrating that the Redwine mode could be executed in different ways at the same time and place. In addition to the two Redwine mode vessels, Burial 1 also contained a Pease Brushed-Incised jar and a small bottle with engraved concentric circles on the body. A smoothing pebble such as was used in pottery production was located at the right shoulder of the deceased individual.

\section{Burial 1, Vessel 1 (Figure 9)}

VESSEL FORM: Carinated bowl; the Redwine mode rim has 18 evenly spaced lobes that are at right angles to the wall of the vessel. The lobes average $6.5 \mathrm{~mm}$ in thickness and extend outward $17 \mathrm{~mm}$ from the mouth of the vessel. There are also two opposing strap handles on the rim.

NON-PLASTICS: Grog

CORE COLOR: B (fired and cooled in a reducing environment)

WALL THICKNESS: $5.7 \mathrm{~mm}$

INTERIOR SURFACE COLOR: black (10YR2/1)

EXTERIOR SURFACE COLOR: black (10YR2/1)

INTERIOR SURFACE TREATMENT: Burnished

EXTERIOR SURFACE TREATMENT: Polished

HEIGHT: $5.5 \mathrm{~cm}$

ORIFICE DIAMETER: $10.5 \mathrm{~cm}$

BASE DIAMETER: $4.4 \mathrm{~cm}$

DECORATION: Engraved scrolls similar to Hart's Nacogdoches Engraved Mode 3 (Hart 1982:47 and Figure 3-4) with cross-hatched fill elements. There are engraved circles inside cross elements on both of the strap handles.

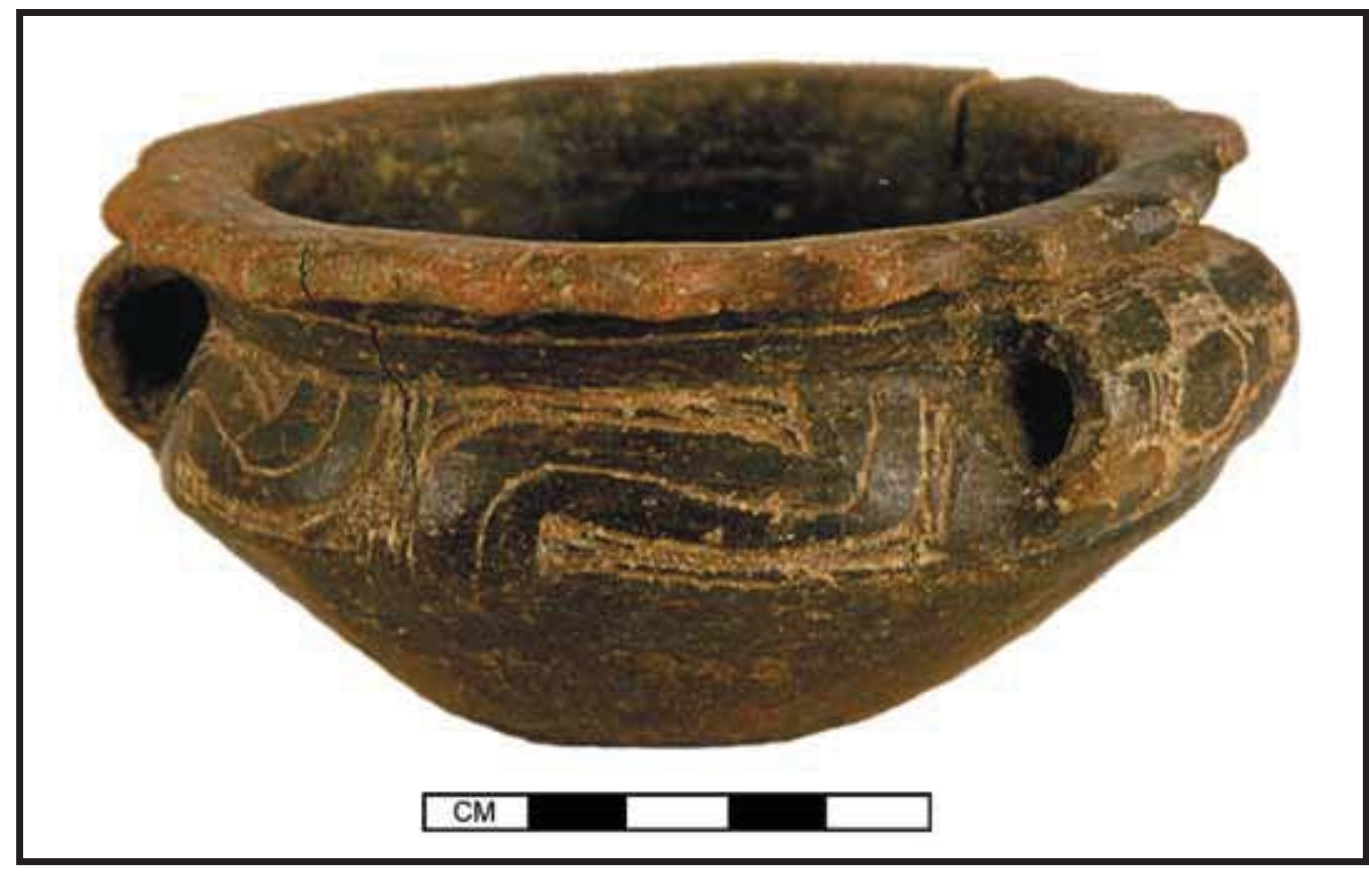

Figure 9. Carinated bowl with Redwine mode rim from 41SM223, Burial 1, Vessel 1. 


\section{Burial 1, Vessel 2 (Figure 10)}

VESSEL FORM: Carinated bowl with evenly spaced lobes articulated at a greater than 90 degree angle from the body of the vessel.

NON-PLASTICS: Grog, hematite, and heavy bone

CORE COLOR: G (reduced firing and cooled in open air)

INTERIOR SURFACE COLOR: brown (7.5YR4/3)

EXTERIOR SURFACE COLOR: reddish-yellow (7.5YR6/6)

INTERIOR SURFACE TREATMENT: smoothed but badly eroded

EXTERIOR SURFACE TREATMENT: burnished but badly eroded

HEIGHT: $9.5 \mathrm{~cm}$

ORIFICE DIAMETER: $18.5 \mathrm{~cm}$

BASE DIAMETER: $6.5 \mathrm{~cm}$

DECORATION: Three horizontal rows of tool punctates on the rim joined by punctated columns, forming rectangular interlocking panels.

TYPE: Washington Square Paneled -(Hart 1982:71-75).

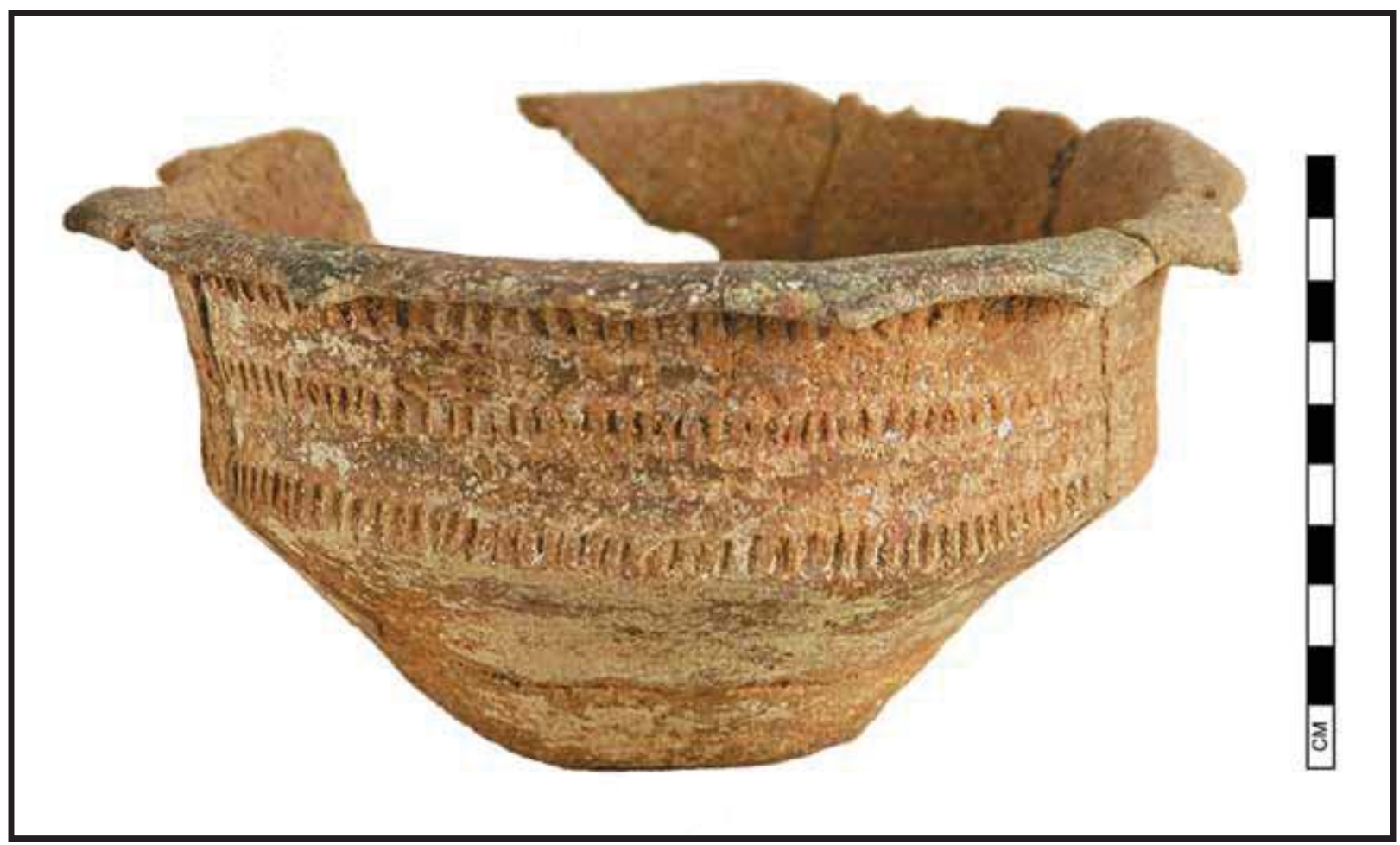

Figure 10. Carinated bowl with Redwine mode rim from 41SM223, Burial 1, Vessel 2. 


\section{The Pardee Site (41SM198)}

This Caddo site is located near the Redwine site and 41SM223 on the headwaters of Auburn Creek in eastern Smith County, Texas. All three sites have Middle Caddo occupations and examples of Redwine mode rims. The example from the Pardee site is from a carinated bowl with a Washington Square Paneled design (Figure 11).

VESSEL NO.: Burial 1

NON-PLASTICS: grog

VESSEL FORM: carinated bowl with Redwine mode rim

RIM AND LIP FORM: direct, rounding

CORE COLOR: A (oxidized)

INTERIOR SURFACE COLOR: strong brown (7.5YR5/6)

EXTERIOR SURFACE COLOR: strong brown (7.5YR5/6)

WALL THICKNESS (RIM, BODY, AND BASE IN MM): 5.7 rim

INTERIOR SURFACE TREATMENT: smoothed

EXTERIOR SURFACE TREATMENT: smoothed

HEIGHT (IN CM): 8.6

ORIFICE DIAMETER (IN CM): 19.0

DIAMETER AT BOTTOM OF RIM OR NECK (IN CM): 16.5

BASE DIAMETER (IN CM): 8.6

ESTIMATED VOLUME (IN LITERS): 0.98 liters

DECORATION: bands of tool punctates within incised panels

TYPE: Washington Square Paneled

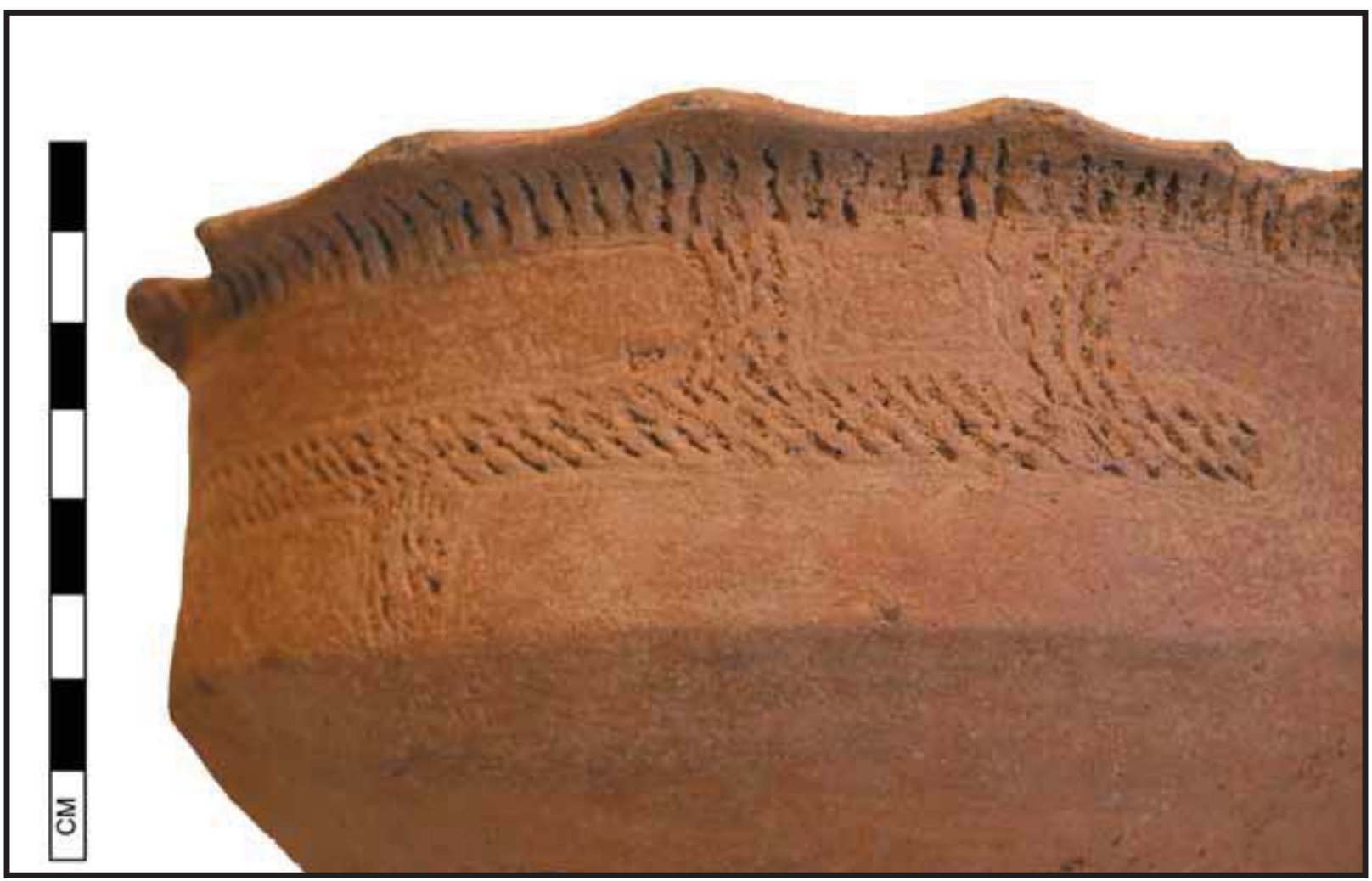

Figure 11. Washington Square Paneled carinated bowl with Redwine mode rim from 41SM198. 


\section{Leaning Rock (41SM325)}

Leaning Rock is a Caddo habitation area with calibrated dates ranging from AD 1280-1420. (The average calibrated radiocarbon intercept date is cal AD 1349 (Walters 2008). Three sherds with Redwine mode rims were recovered from excavations in a midden area.

\section{Sherd 1, Unit 4, 30-40 cm bs (Walters 2008:Figure 20a) (Figure 12)}

VESSEL FORM: Probably from a large carinated bowl. The sherd has a 90 degree folded rim with two rounded lobes that are $11.6 \mathrm{~mm}$ in thickness. The supporting vessel wall is $7.6 \mathrm{~mm}$ thick. The upper surface of the lobes is flattened but undecorated.

NON-PLASTICS: Grog and bone

CORE COLOR: $\mathrm{F}$ (reduced firing and cooled in the open air)

INTERIOR SURFACE COLOR: brown (10YR4/3)

EXTERIOR SURFACE COLOR: dark grayish-brown (10YR3/2)

INTERIOR SURFACE TREATMENT: Burnished

EXTERIOR SURFACE TREATMENT: Burnished

DECORATION: The rim has vertical and curvilinear zones of incised lines and there is a row of linear punctates underneath the lobes.

TYPE: Washington Square Paneled

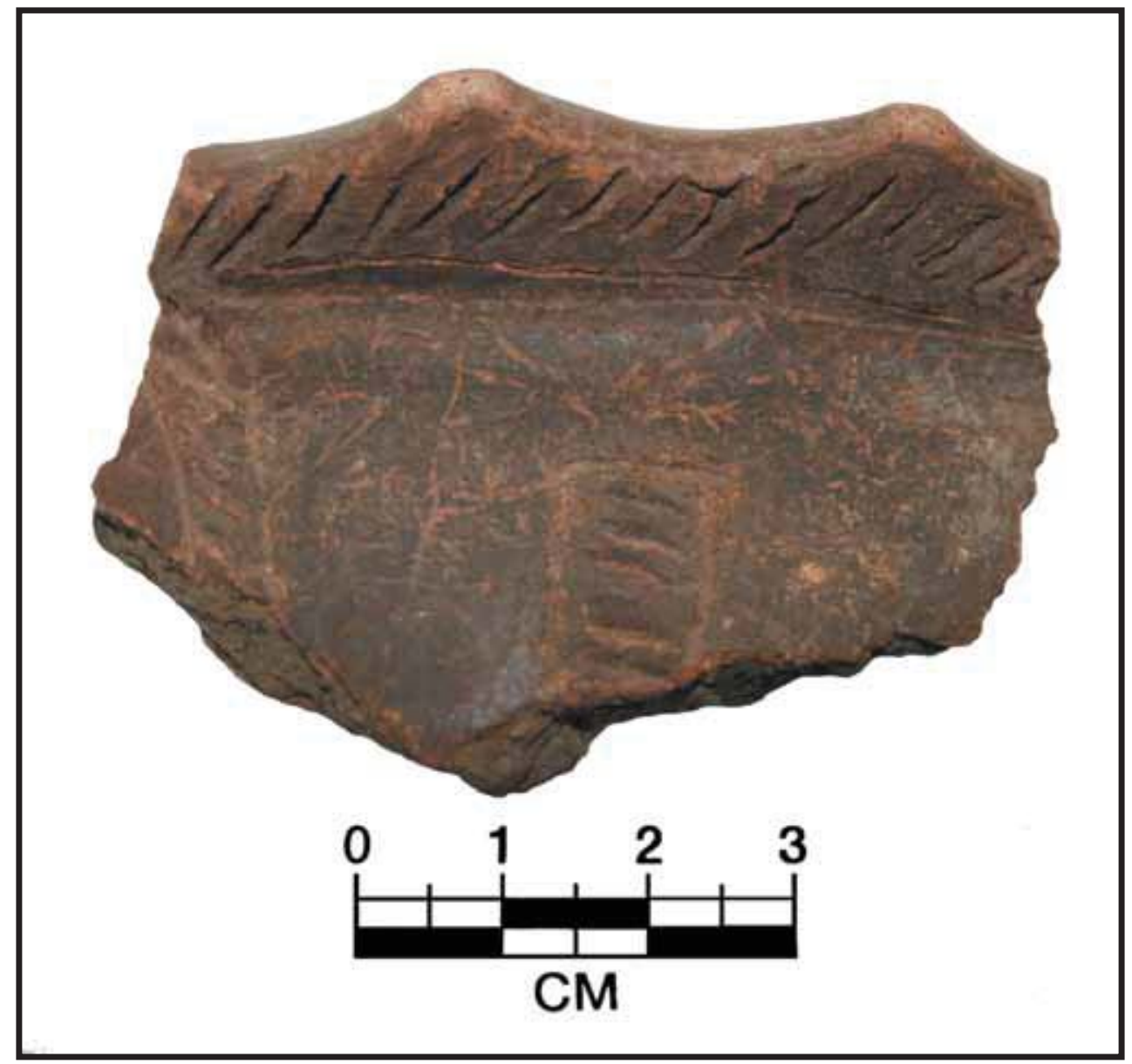

Figure 12. Redwine mode rim sherd from the Leaning Rock site, Unit 9, 20-30 cm bs. 
VESSEL FORM: Large carinated bowl. The rim has two lobes, and it is at right angles to the vessel wall. The lobes are flattened but not decorated on the upper surface. The lobes are $10.9 \mathrm{~mm}$ thick, compared to $7.7 \mathrm{~mm}$ thickness for the vessel wall.

NON-PLASTICS: Grog, bone, and hematite

CORE COLOR: $\mathrm{F}$ (reduced firing and cooled in the open air)

INTERIOR SURFACE COLOR: brown (7.5YR4/3)

EXTERIOR SURFACE COLOR: dark grayish-brown (10YR3/2)

INTERIOR SURFACE TREATMENT: Burnished

EXTERIOR SURFACE TREATMENT: Burnished

DECORATION: The rim has vertical and curvilinear zones of incised lines and there is a row of linear punctates underneath the lobes.

TYPE: Washington Square Paneled

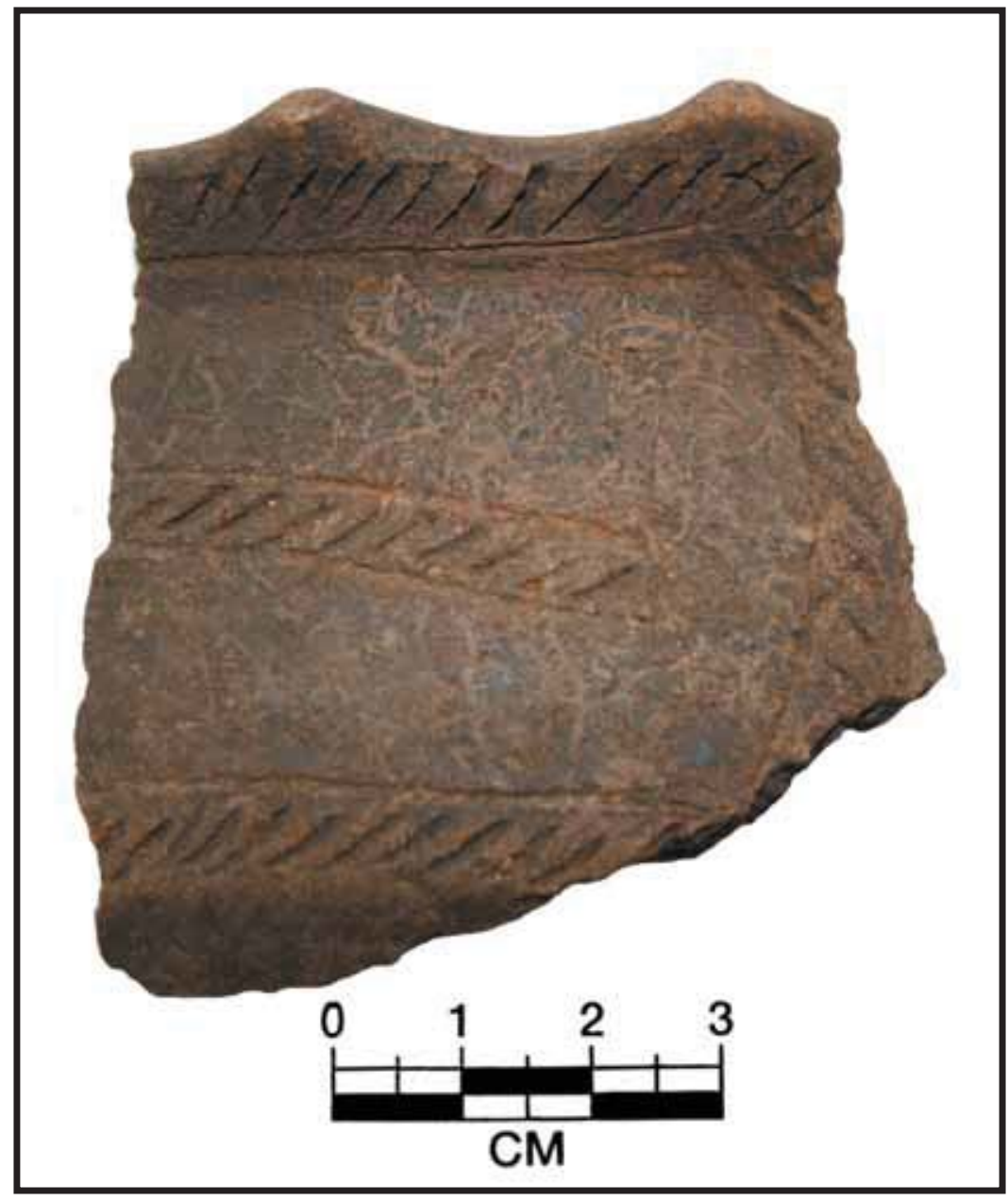

Figure 13. Rim sherd with Redwine mode rim from the Leaning Rock site (41SM325), Unit 4, 30-40 cm bs. 


\section{Sherd 3, Unit 9, 20-30 cm bs (Walters 2008:Figure 20c) (Figure 14)}

VESSEL FORM: Probably a large carinated bowl with a rim that is flattened on the top, but it has undecorated lobes that radiate out from the rim at a right angle. The lobe is $9.8 \mathrm{~mm}$ thick compared to the $7.2 \mathrm{~mm}$ thick vessel wall. On this example, the lobes are not as pronounced as the other two from the site.

NON-PLASTICS: Grog

CORE COLOR: B (reduced firing and cooling)

INTERIOR SURFACE COLOR: yellowish-brown (10YR5/4); fire clouding

EXTERIOR SURFACE COLOR: dark grayish-brown (10YR3/2); fire clouding

INTERIOR SURFACE TREATMENT: Burnished

EXTERIOR SURFACE TREATMENT: Burnished

DECORATION: The rim has horizontal incised scrolls and incised columns (interlocking scrolls?), with a row of punctates underneath the lobes.

TYPE: Washington Square Paneled

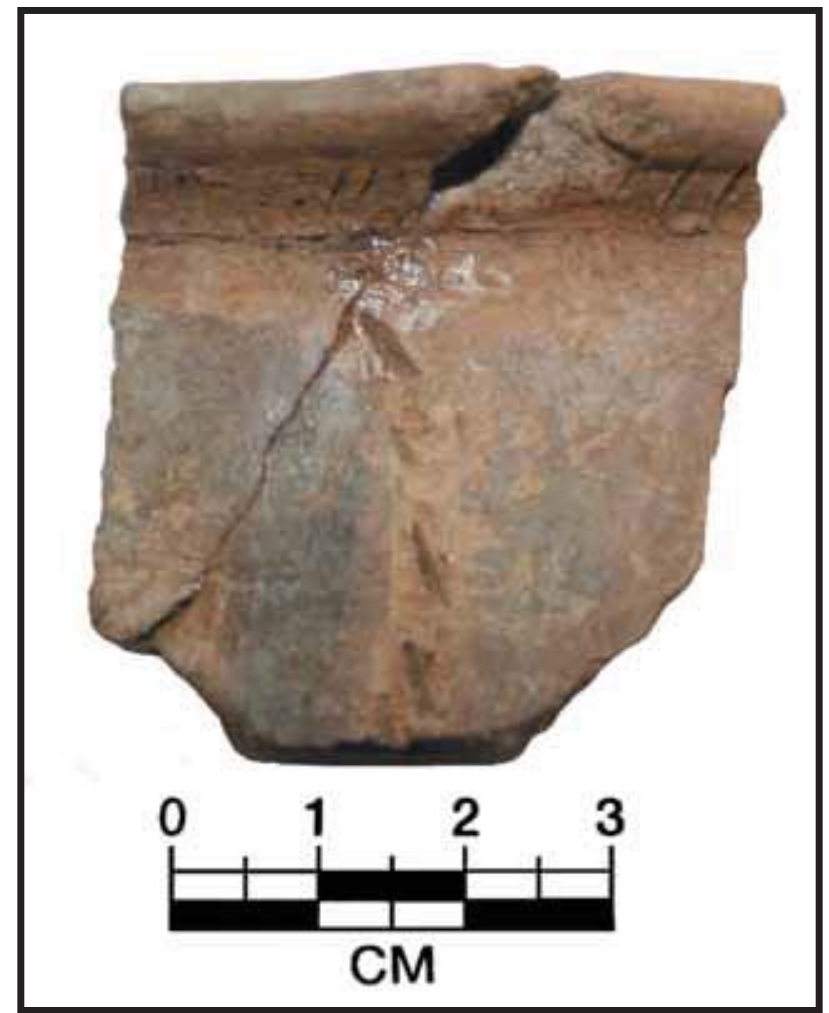

Figure 14. Rim sherd with Redwine mode rim from the Leaning Rock site, Unit 11, 20-30 cm bs.

\section{Brooks Site (41SM196)}

The Brooks site is on a neighboring small drainage from the Leaning Rock site and ca. 8 miles from Redwine. Although not radiocarbon-dated, the prehistoric Caddo occupation appears to date to the Middle Caddo period based on the presence of Perdiz arrow points, brushed pottery, and certain engraved elements on vessels, such as ladders. There is one rim sherd from the surface that has a Redwine mode rim. It is badly eroded, with a portion of the lobe is missing, but the top is folded out at a radical angle from the wall of the vessel ( $5.7 \mathrm{~mm}$ thick), forming a lobe that is $8.2 \mathrm{~mm}$ thick. The angle of the vessel wall suggests a simple bowl form similar to Vessel 1 from the Redwine site. The temper is grog and bone and the sherd has a sandy paste. There is a single horizontal line under the lip that cannot be identified as either engraved or incised due to its eroded condition. The vessel appears to have been fired in an oxidizing atmosphere. 


\section{Sherd 1 (Sherman et al. 2001:108)}

During test excavations in the Martin Creek drainage in the Sabine River basin, at the Oak Hill Mine, a possible Washington Square Paneled rim sherd with a Redwine rim mode was recovered and documented (Sherman et al. 2001:108). This site dates to the Middle Caddo period.

The grog-tempered sherd closely resembles Redwine mode sherds from the Leaning Rock site (41SM325). The articulated portion on this sherd has a row of finely executed punctates on the underside of the lobes.

\section{HS718}

\section{Sherd 1 (Gadus et al. 2006:Figure 4-40, Vessel 1), 41 HS718 (Figure 15)}

Test excavations at 41HS718 recovered a vessel with a Redwine mode rim (Gadus et al. 2006:8283). This grog-tempered vessel was found in a Middle Caddo period burial (Gadus et al. 2006:91). Although identified as Glassell Engraved by Gadus et al. (2006), the rectangular panel design, formed by punctates, more closely resembles the decorative elements seen on Washington Square Paneled vessels (Hart 1982). In profile, the rim is folded out at a right angle from the vessel body and the lip has evenly spaced lobes, thus closely resembling Redwine mode rims from other sites in the area.

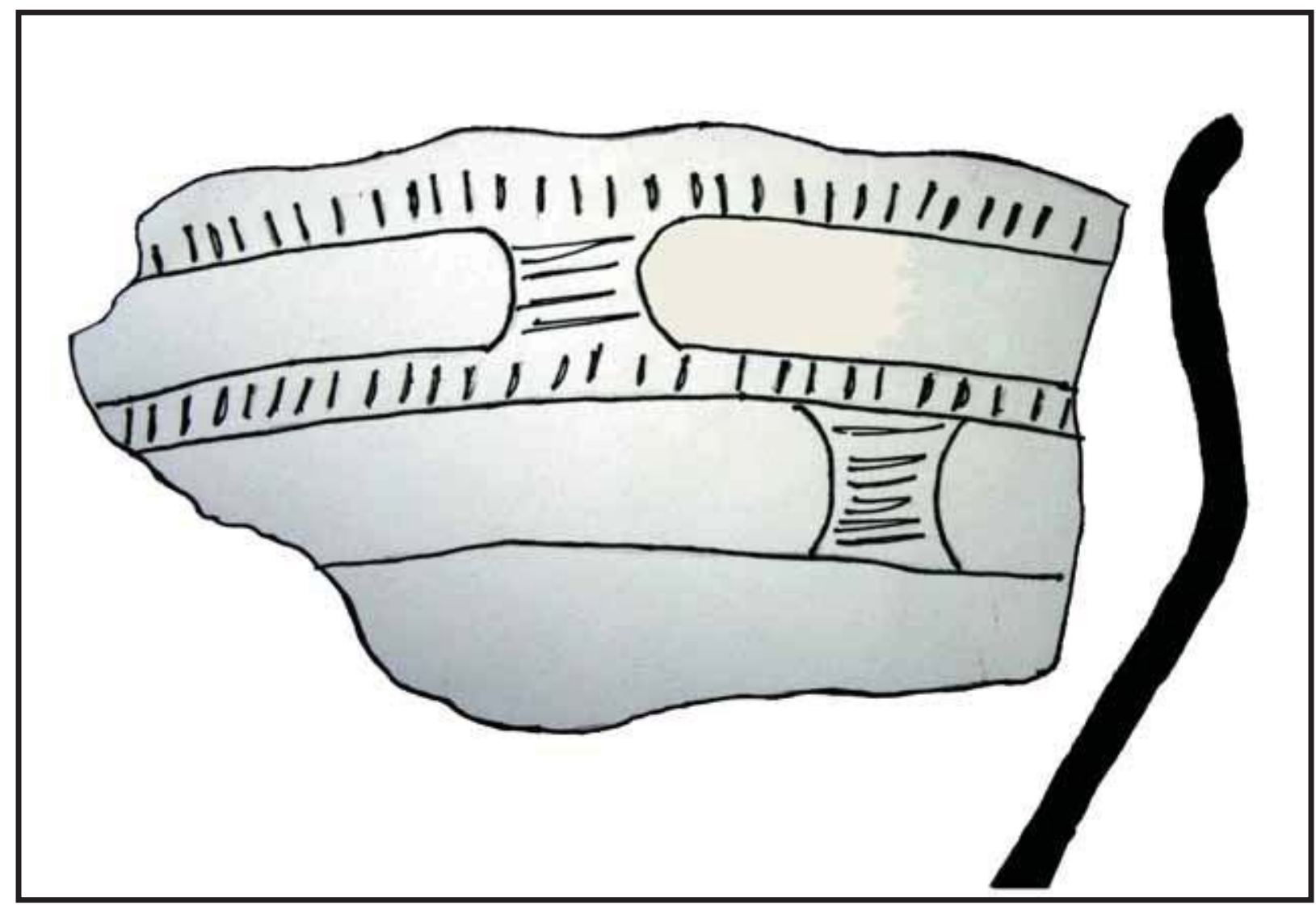

Figure 15. Rim sherd with Redwine mode rim from 41HS718. 


\section{Buddy Jones Collection Redwine Mode examples (Perttula 2006:8-9, 52, 108)}

\section{Vessel 1 (Perttula 2006:Figure 15), B-1 TAS}

This is a Washington Square Paneled carinated bowl with an engraved and punctated decorative motif on the rim (Figure 16). TAS is possibly the Henry Spencer site in Upshur County, or the A. Smith site, also in Upshur County.

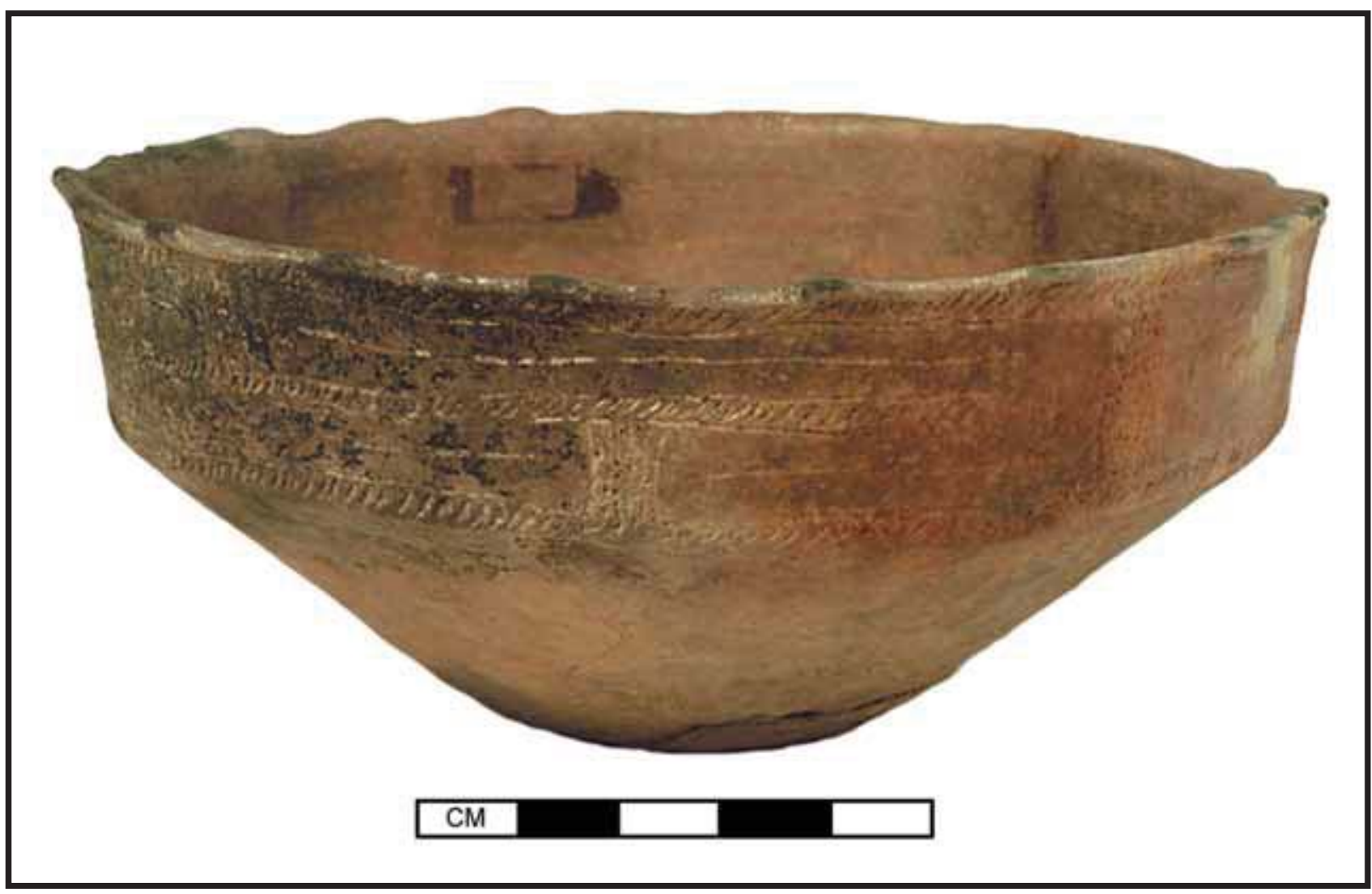

Figure 16. Washington Square Paneled vessel with Redwine mode rim, Vessel 1 (Perttula 2006:Figure 15), B-1, TAS. 


\section{Vessel 2 (Perttula 2006:Figure 18), B-3 TAS}

This second vessel is also a Washington Square Paneled carinated bowl with an engraved and punctated motif on the rim.

\section{Vessel 3 (Perttula 2006:Figure 151), A38, S.S.}

The third vessel is an engraved carinated bowl with a series of festoon lines creating negative panels around the rim (Figure 17). The S.S. site may be the Spencer site or the Susie Slade site, or vessels with the "S.S." label may represent a combination of the two sites in the Jones collection.

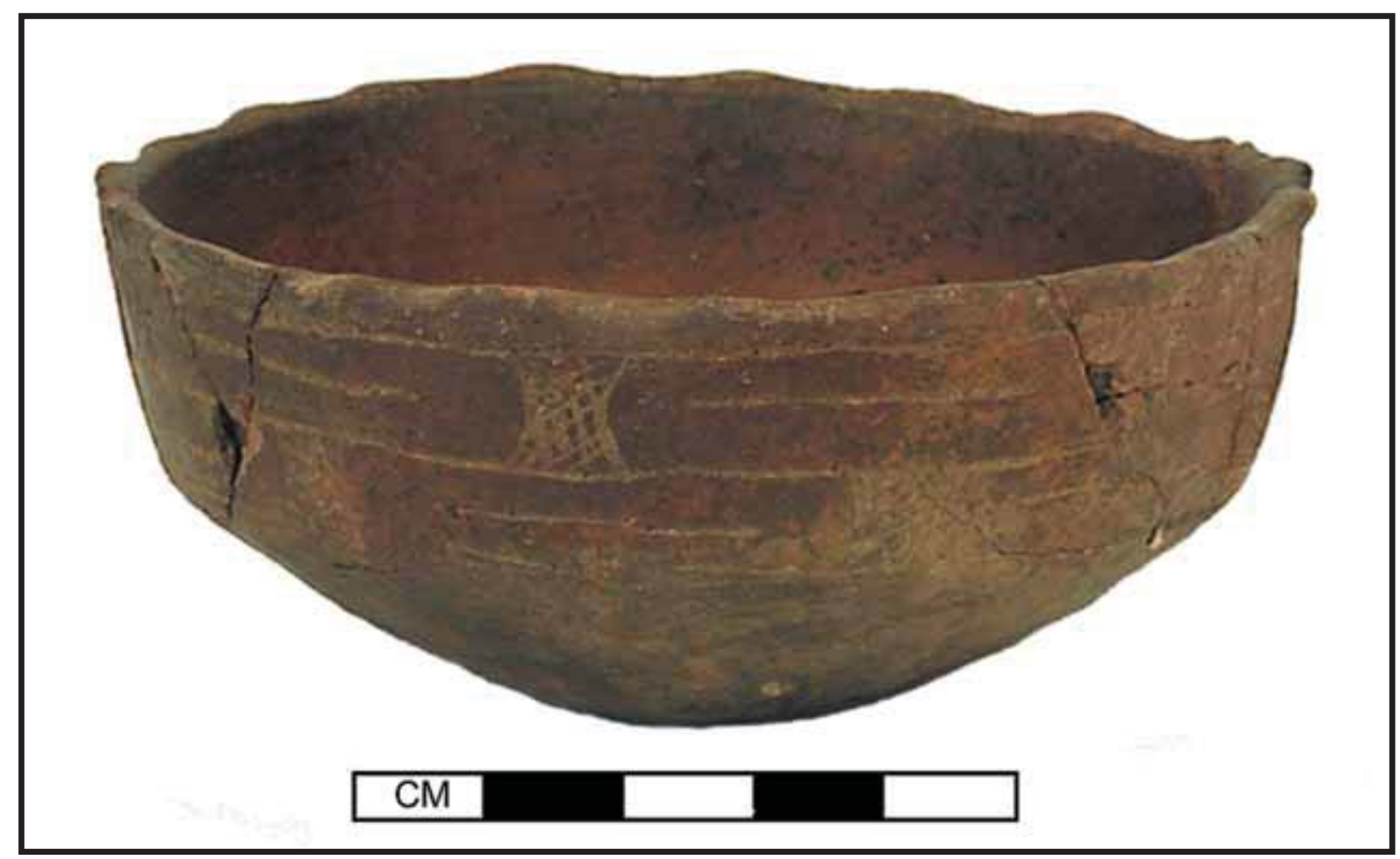

Figure 17. Engraved carinated bowl with Redwine mode rim, Vessel 3 (Perttula 2006:Figure 151), A38, S.S. 


\section{Vessel 4 (Perttula 2006:Figure 308), B-3 Field Site}

The fourth vessel in the Jones collection is a Ripley Engraved carinated bowl with an engraved scroll and semi-circle motif on the rim. The location of the Fields site is unknown.

\section{G.C. 108}

During more recent documentation of the Buddy C. Jones Collection at the Gregg County Historical Museum another example of a Redwine mode rim was noted. This rim sherd came from site G.C. 108, on Moody Creek, in Gregg County, Texas.

SITE NAME OR SITE NUMBER: G.C. 108

NON-PLASTICS: grog

VESSEL FORM: carinated bowl with Redwine mode rim

RIM AND LIP FORM: direct, rounding

CORE COLOR: B (fired and cooled in an reducing environment)

INTERIOR SURFACE COLOR: dark grayish-brown (10YR4/2)

EXTERIOR SURFACE COLOR: dark grayish-brown (10YR4/2)

WALL THICKNESS (RIM, BODY, AND BASE IN MM): 6.2, rim; 5.6, body

INTERIOR SURFACE TREATMENT: smoothed

EXTERIOR SURFACE TREATMENT: rim burnished

ORIFICE DIAMETER (IN CM): 18.5

DECORATION: row of tool punctates under lip

TYPE: cf. Washington Square Paneled

\section{Lang Pasture Site (41AN38), by Timothy K. Perttula}

The Lang Pasture site is a ca. A.D. 1350-1450 Caddo habitation site and cemetery in the upper Neches River basin. Two of the vessels from one burial (Feature 8) have Redwine mode rims. Also found in this burial were a plain bottle, a Maydelle Incised jar, and three plain carinated bowls, one of which has a interior and exterior red slip. 
VESSEL FORM: Carinated bowl with a Redwine mode rim NON-PLASTICS: grog and bone

CORE COLOR: B (fired and cooled in a reducing environment)

WALL THICKNESS: $5.0 \mathrm{~mm}$, rim; $4.1 \mathrm{~mm}$, body

INTERIOR SURFACE TREATMENT: burnished

EXTERIOR SURFACE TREATMENT: burnished

HEIGHT: $9.1 \mathrm{~cm}$; rim height is $3.52 \mathrm{~cm}$

ORIFICE DIAMETER: $17.8 \mathrm{~cm}$

ESTIMATED VOLUME: 1.0 liter

DECORATION: The rim has an engraved motif repeated 10 times around the vessel between upper and lower horizontal engraved lines. The motif is comprised of an engraved triangle with either horizontal or diagonal hatched lines at each of the three corners of the triangle. The points of the triangle rotate from touching the tip of the rim to touching the carination. Two diagonal engraved lines separate the triangles from each other. The distinctive engraved motif is comparable to Poynor Engraved vessels recovered from other sites in the upper Neches River basin.

TYPE: Poynor Engraved

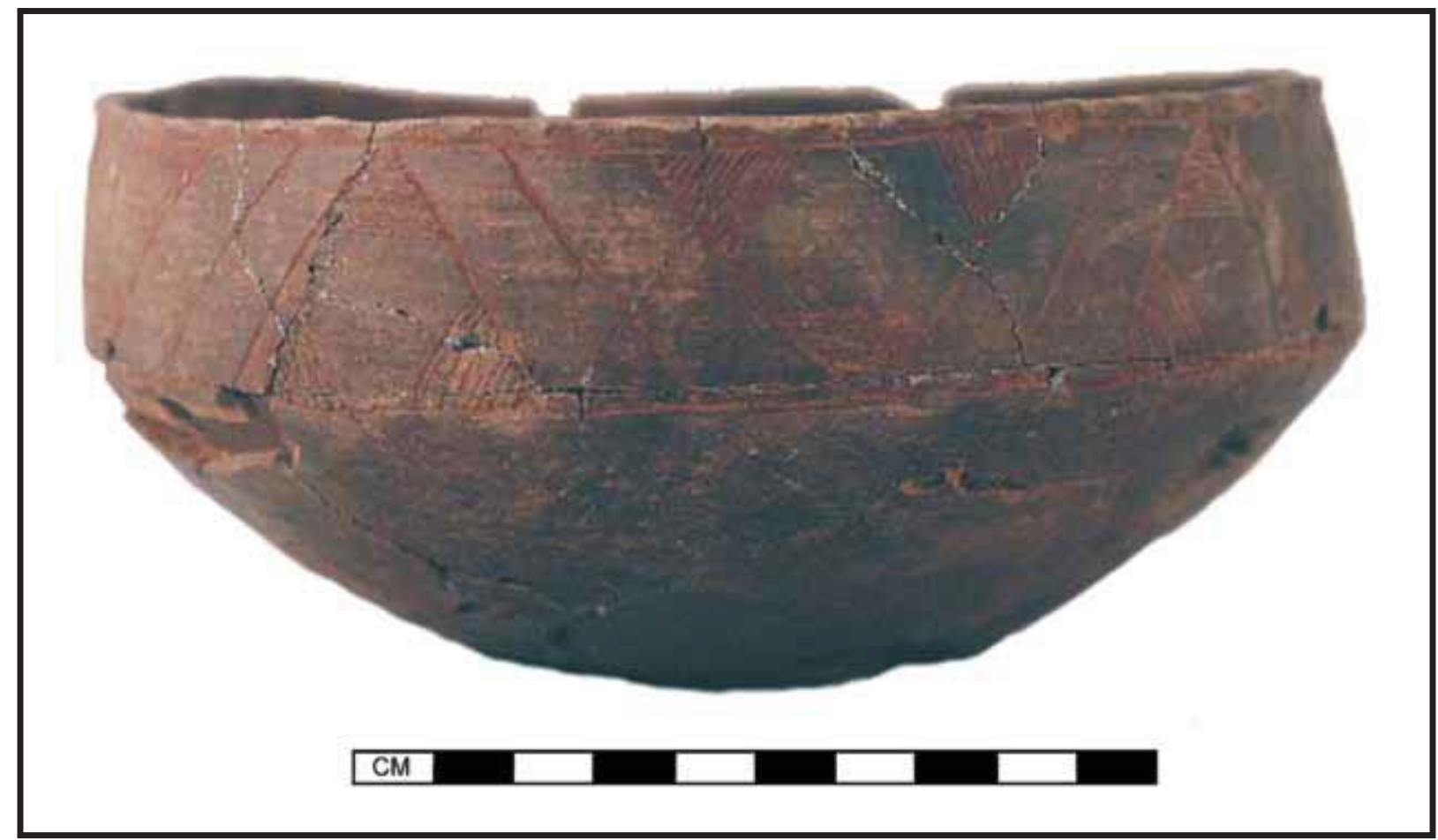

Figure 18. Poynor Engraved carinated bowl with Redwine mode rim, Lang Pasture site (41AN38), Feature 8, Vessel 3. 


\section{VESSEL 4, FEATURE 8}

VESSEL FORM: Bowl with an interior thickened Redwine mode rim

NON-PLASTICS: grog, bone, and hematite

CORE COLOR: B (fired and cooled in an reducing environment)

WALL THICKNESS: $5.35 \mathrm{~mm}$, rim; $4.7 \mathrm{~mm}$, body

INTERIOR SURFACE TREATMENT: burnished

EXTERIOR SURFACE TREATMENT: burnished

HEIGHT: $5.5 \mathrm{~cm}$; Rim height, $11.0 \mathrm{~mm}$ in non-scalloped sections and $16.5 \mathrm{~mm}$ in scalloped lip sections

ORIFICE DIAMETER: $16.3 \mathrm{~cm}$

DIAMETER AT BOTTOM OF RIM OR NECK: undetermined

BASE DIAMETER: undetermined

ESTIMATED VOLUME: 0.35 liters

DECORATION: plain

TYPE: undetermined plain ware vessel

\section{Cluster 2 Sites}

The second cluster of sites with Redwine mode rim vessels includes five sites in Cherokee, Nacogdoches, and Shelby counties (see Figure 4). This includes both the Washington Square Mound site as well as the George C. Davis site.

\section{Washington Square Mound Site Redwine Mode pie-crust rim vessels, by Timothy K. Perttula}

A distinctive characteristic of the Washington Square Mound site (41NA49) funerary vessels from Features 31 and 95 are certain rim treatments (Perttula et al. 2009a). This includes four vessels (F31-3, F315, F31-10, and F95-20) with rim peaks (including one with strap handles), one with a scalloped lip (F9521), and four (F31-7, F95-6, F95-22, and F95-32) with a Redwine or pie-crust rim mode (Figures 14-17). These particular vessel rims are articulated, forming right angles from the body of the vessel, and the lips are scalloped.

More than $8.5 \%$ of the vessels from Features 31 and 95 have rim peaks, another $8.5 \%$ have Redwine mode rims, and $2.1 \%$ have scalloped lips. Vessels with rim peaks are more abundant in the Feature 31 funerary vessels $(20 \%)$ than in the Feature 95 vessels (3\%), while Redwine mode rims are slightly more prevalent in Feature 95 (9.4\%) than in Feature 31 (6.7\%); the one scalloped rim vessel is from Feature 95.

Rim peak vessels include a Nacogdoches Engraved compound bowl, two Reavely Brushed-Incised jars, and one Washington Square Paneled compound bowl (see Hart [1982] for definitions of these Caddo ceramic types). The scalloped lip vessel is a Washington Square Paneled carinated bowl. Three of the four Redwine rim mode vessels are engraved - two carinated bowls, one identified as Nacogdoches Engraved and the other with rectilinear and continuous scrolls, and the third is an engraved bowl with a Mode $A$ decoration (Hart 1982:78; Mode A rim sherds have been identified in Middle Caddo contexts at the Oak Hill Village site, see Rogers and Perttula [2004] in post-A.D. 1350 contexts) —and the fourth is a Reavely Brushed-Incised jar.

The four Redwine rim mode vessels from the Washington Square Mound site are described as follows, by feature: 
FEATURE 31

VESSEL NO.: F31-7 (Figure 19)

NON-PLASTICS: bone and grog

VESSEL FORM: Jar with an everted rim in the Redwine mode (i.e., flat on top and folded over at almost a 90 degree angle from the body of the vessel)

CORE COLOR: E (incompletely oxidized during firing)

INTERIOR SURFACE COLOR: yellowish-red (5YR4/6)

EXTERIOR SURFACE COLOR: yellowish-red (5YR4/6) with black fire clouding

WALL THICKNESS: $6.8 \mathrm{~mm}$

INTERIOR SURFACE TREATMENT: burnished

EXTERIOR SURFACE TREATMENT: smoothed at the rim-body juncture

HEIGHT: $12.2 \mathrm{~cm}$

ORIFICE DIAMETER: $18.0 \mathrm{~cm}$

DIAMETER AT BOTTOM OF RIM OR NECK: Undetermined

BASE DIAMETER: $10.0 \mathrm{~cm}$

ESTIMATED VOLUME: 1.9 liters

DECORATION: The rim has a zone of slash punctates under the vessel lip. The body has vertical brushing in eight panels separated by vertical appliqued fillets; these panels extend from the rim-body juncture to just above the base. There are also vertical rows of small punctations on the body within each of the brushedappliqued panels.

TYPE: Reavely Brushed-Incised (Hart 1982:Figure 3-10a).

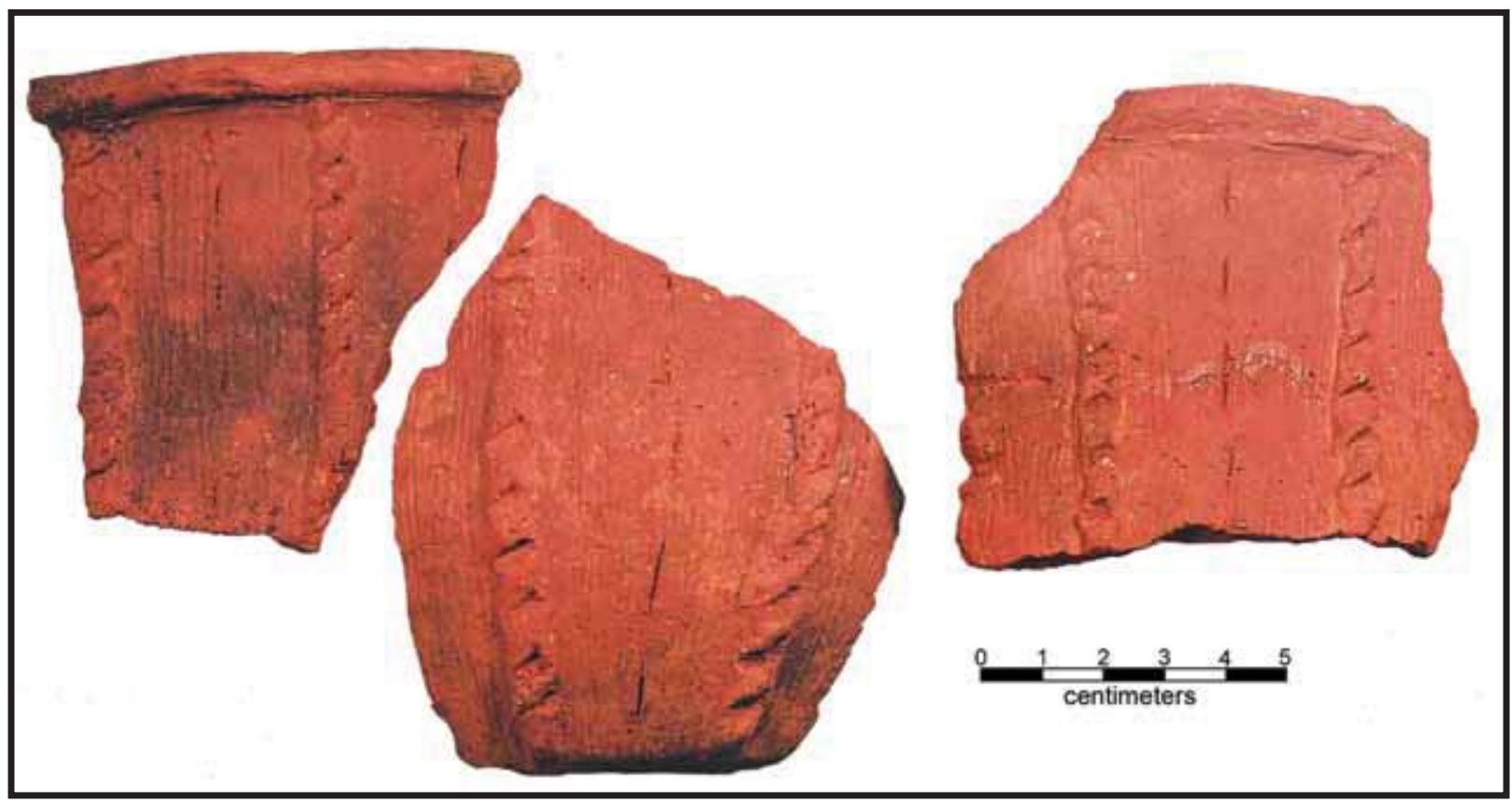

Figure 19. Reavely Brushed-Incised jar from Feature 31 at the Washington Square Mound site (41NA49)with Redwine mode rim. 


\section{FEATURE 95}

VESSEL NO.: F95-6 (Figure 20a-b)

NON-PLASTICS: bone

VESSEL FORM: Bowl with a direct rim and a broad, flat lip; the rim is a Redwine mode with 16 scallops at the lip

CORE COLOR: B (fired and cooled in a reducing environment)

INTERIOR SURFACE COLOR: very dark gray (10YR3/1)

EXTERIOR SURFACE COLOR: pale brown (10YR6/3)

WALL THICKNESS: $8.4 \mathrm{~mm}$

INTERIOR SURFACE TREATMENT: burnished

EXTERIOR SURFACE TREATMENT: burnished, but eroded

HEIGHT: $5.0 \mathrm{~cm}$

ORIFICE DIAMETER: $15.5 \mathrm{~cm}$

DIAMETER AT BOTTOM OF RIM OR NECK: N/A

BASE DIAMETER: $10.4 \mathrm{~cm}$

ESTIMATED VOLUME: 0.3 liters

DECORATION: The rim has an engraved motif (labeled Mode A engraved by Hart [1982:78 and Figure 3-13a]) repeated four times around the vessel; each repeated motif is separated from the other by one or two vertical engraved lines. The engraved motif consists of squares with triangular-shaped hatched corners and a small, engraved circle in the center of the square. Three of the small circles are filled with cross-hatched lines, but one has vertical engraved lines within it.

TYPE: Undetermined Engraved (Hart 1982:Figure 3-13b), but closely resembles examples of Poynor Engraved (cf. Suhm and Jelks 1962).
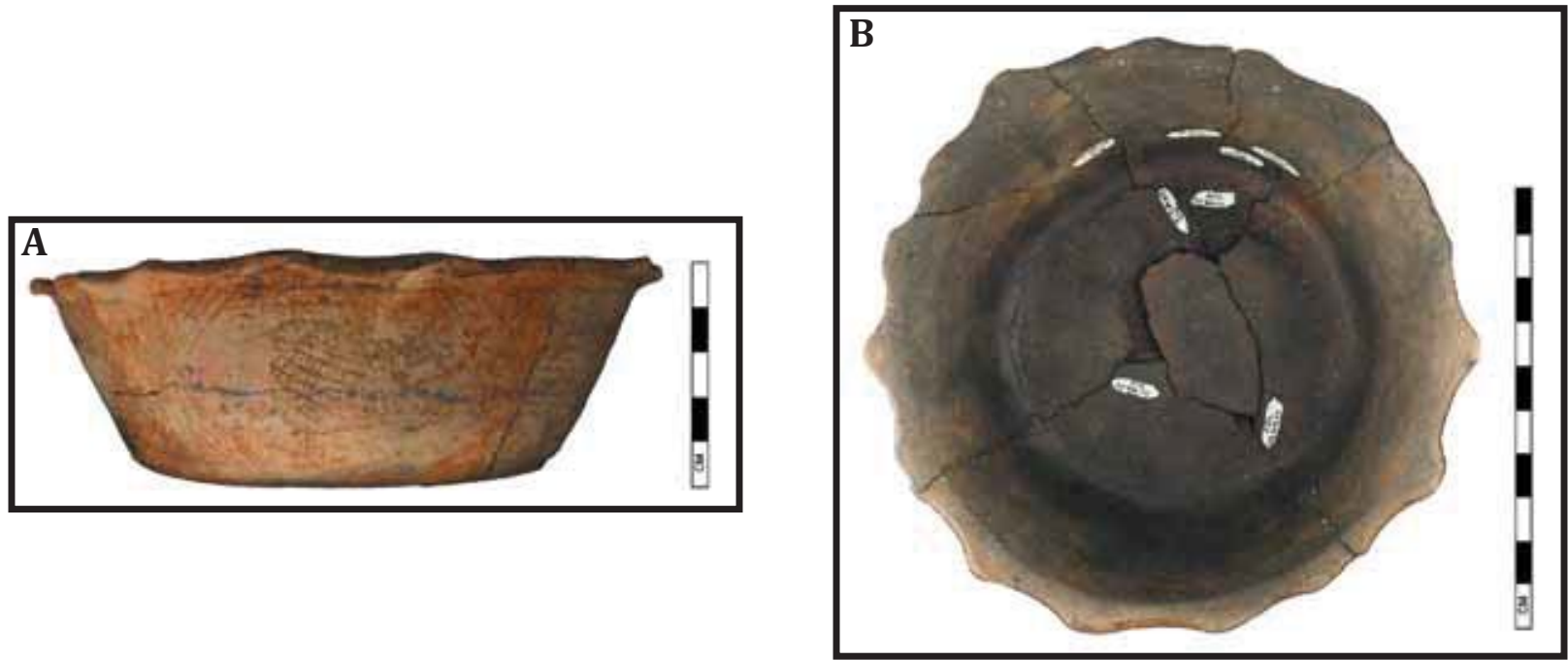

Figure 20. Bowl with Redwine mode rim, Washington Square Mound site, Feature 95, Vessel No. F95-6. a, side view; b, top view. 


\section{FEATURE 95}

VESSEL NO.: F95-22 (Figure 21a-b)

NON-PLASTICS: grog

VESSEL FORM: Carinated bowl with a direct Redwine mode rim and a flat lip

CORE COLOR: B (fired and cooled in a reducing environment)

INTERIOR SURFACE COLOR: dark grayish-brown (10YR4/2) to black (10YR2/1)

EXTERIOR SURFACE COLOR: very dark grayish-brown (10YR3/2)

WALL THICKNESS: $5.6 \mathrm{~mm}$

INTERIOR SURFACE TREATMENT: burnished

EXTERIOR SURFACE TREATMENT: burnished

HEIGHT: $6.0 \mathrm{~cm}$

ORIFICE DIAMETER: $15.0 \mathrm{~cm}$

DIAMETER AT BOTTOM OF RIM OR NECK: $12.6 \mathrm{~cm}$

BASE DIAMETER: $6.9 \mathrm{~cm}$

ESTIMATED VOLUME: 0.55 liters

DECORATION: Engraved rectilinear continuous scrolls repeated six times around the vessel rim. Fill zones above and below each of the scrolls are composed of hatched areas and negative ovals, one in each fill zone. Narrow vertical cross-hatched zones divide the scrolls, except in one instance where the vertical hatched zone was not executed.

TYPE: Undetermined engraved fine ware vessel (Hart 1982:Figure 3-14b).
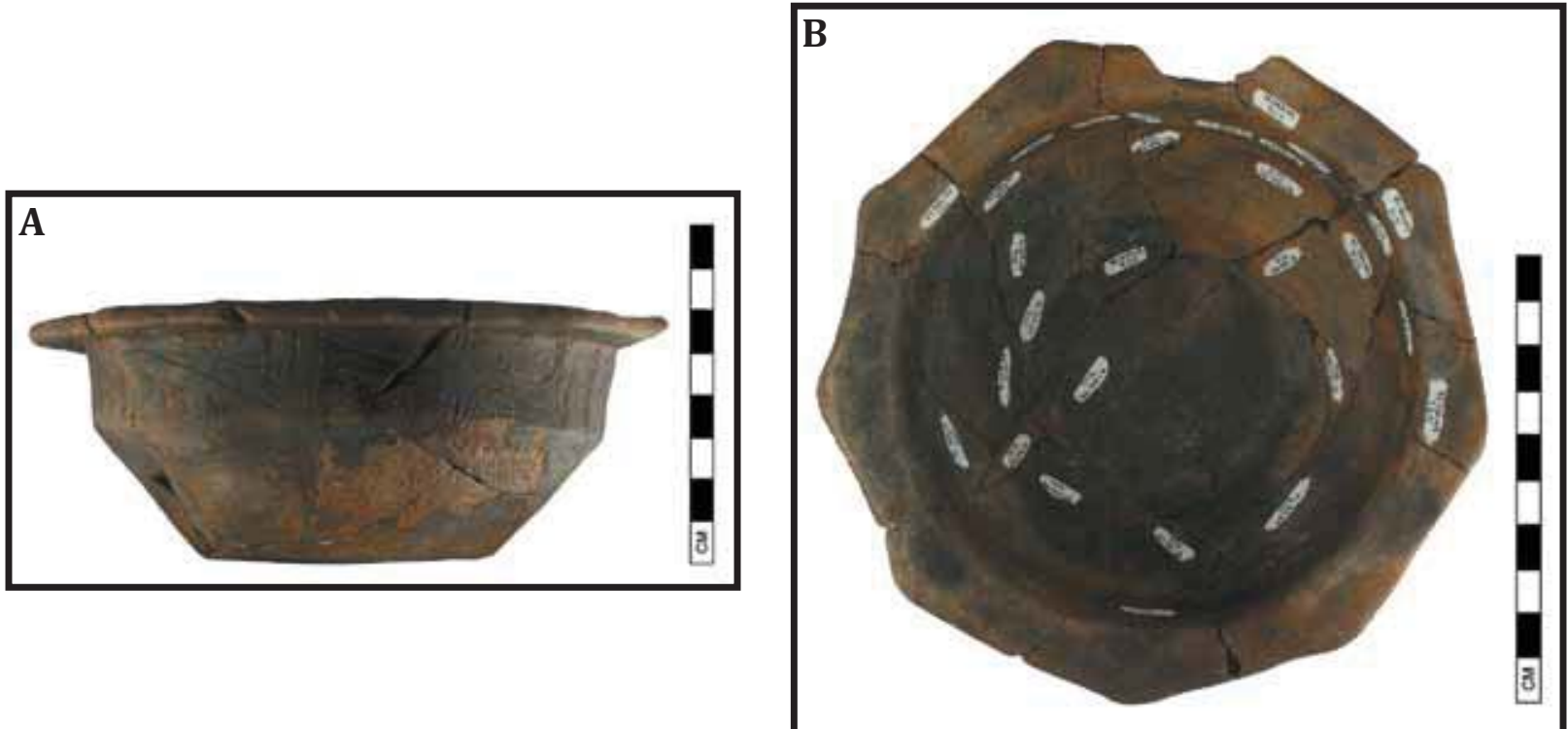

Figure 21. Carinated bowl with Redwine mode rim, Washington Square Mound site, Feature 95, Vessel No. F95-22, a, side view; b, top view. 


\section{FEATURE 95}

VESSEL NO.: F95-32 (Figure 22a-b)

NON-PLASTICS: grog, bone, and hematite

VESSEL FORM: Carinated bowl with a direct Redwine mode rim and flat lip.

CORE COLOR: F (fired in a reducing environment and cooled in the open air)

INTERIOR SURFACE COLOR: yellowish-red (5YR4/6); fire cloud on base

EXTERIOR SURFACE COLOR: very dark gray (5YR3/1), except on the lip, where it is yellowish-red (5YR4/6)

WALL THICKNESS: $6.2 \mathrm{~mm}$

INTERIOR SURFACE TREATMENT: smoothed on body and rim

EXTERIOR SURFACE TREATMENT: smoothed to burnished on the body and rim

HEIGHT: $7.5 \mathrm{~cm}$

ORIFICE DIAMETER: $23.5 \mathrm{~cm}$

DIAMETER AT BOTTOM OF RIM OR NECK: $18.1 \mathrm{~cm}$

BASE DIAMETER: $8.0 \mathrm{~cm}$

ESTIMATED VOLUME: 1.1 liters

DECORATION: An engraved scroll and circle motif is repeated eight times around the vessel rim. There are hatched pendant triangles or fill zones above and below each of the multi-lined scrolls. Repeated circles with a small, hatched circle in the center form the central circle.

TYPE: Nacogdoches Engraved (Hart 1982:Figure 3-6d).
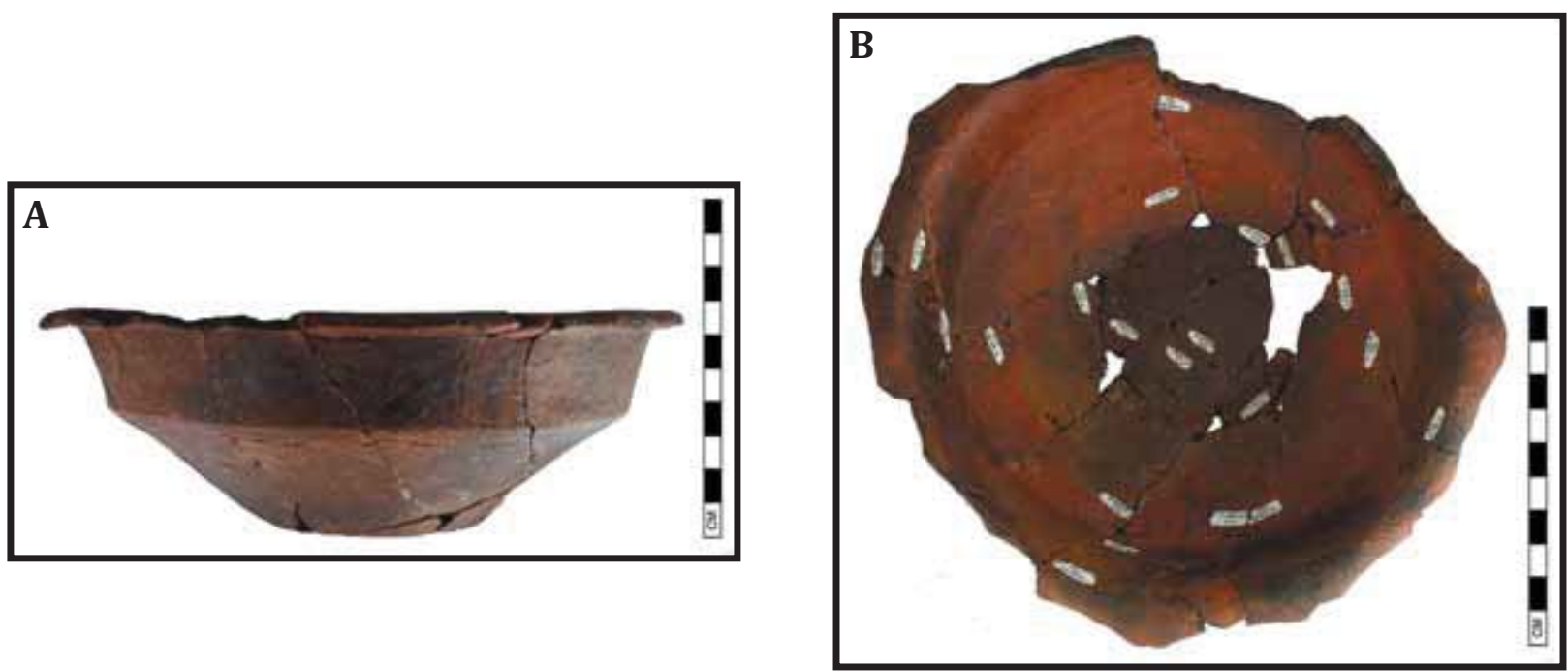

Figure 22. Nacogdoches Engraved carinated bowl with Redwine mode rim, Washington Square Mound site, Feature 95, Vessel No. 95-32, a, side view; b, top view. 


\section{George C. Davis Site (41CE19)}

Rim sherds that compare favorably with the Redwine mode rim include a minimum of eight Holly Fine Engraved and two Crockett Curvilinear Incised vessels (based on rim sherds, not complete vessels) at the George C. Davis site (41CE19) on the Neches River (Newell and Krieger 1949:Figures 30e, 35d, and 37a; Suhm and Jelks 1962:Plates 16g and 39g). The Holly Fine Engraved carinated bowl in Plate 39g is described as having "a scalloped flange bent outward at right angles to the rim" (Suhm and Jelks 1962:77). The distinctive rims at the George C. Davis site likely pre-date A.D. 1300, based on the estimated age when this Caddo mound center was abandoned (Story 2000), and may be the oldest known examples of this form of rim treatment (Perttula et al. 2009a).

\section{Redwine mode vessel from the Tallow Grove Site (41NA231), by Timothy K. Perttula}

Vessel 2 in Feature 45 at the Tallow Grove site (41NA231) on Naconiche Creek in the Attoyac Bayou basin is a Washington Square Paneled carinated bowl (see Hart 1982:Figure 3-12) with a direct rim and a wide and exterior folded and flattened Redwine mode lip (Figure 23). This kind of vessel dates apparently to Middle Caddo period times at the Washington Square Mound site (Corbin and Hart 1998) and other contemporaneous sites in the Sabine and Angelina River basins (see Rogers and Perttula 2004; Walters 2008). Calibrated radiocarbon dates from the Tallow Grove site suggests it was occupied by the Caddo from the early $13^{\text {th }}$ century A.D. to ca. A.D. 1480 (Perttula 2008).

There are eight exterior nodes or rim peaks around the rim of Vessel 2 (Figure 23). The vessel has grog and hematite temper, with charred organic remains in the paste, and it was fired in a reducing environment; the vessel was cooled in the open air. The rim is $5.59 \mathrm{~mm}$ thick, the body walls are $5.39 \mathrm{~mm}$ thick, and the base is $6.83 \mathrm{~mm}$ in thickness. The vessel interior is well smoothed, while the exterior vessel surface has smoothed to burnished patches on it.

This vessel has an engraved design on the rim. The design consists of a series of vertical panels filled with horizontal engraved lines, and these panels extend from the rim to the carination; they are placed immediately below the rim peaks. Between each of the vertical panels are set short horizontal engraved lines with shorter engraved panels or brackets pendant from the horizontal line. These short panels, also filled with horizontal engraved lines, alternately extend either to the rim or to the carination. White kaolin clay has been smeared in the engraved lines.

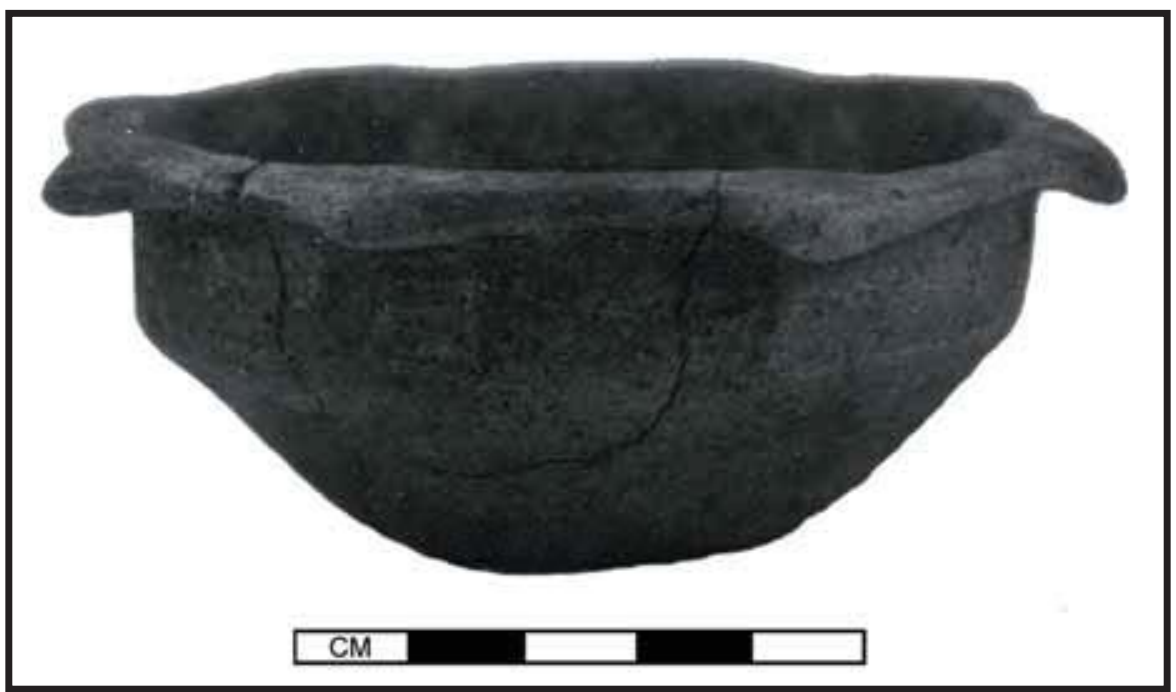

Figure 23. Washington Square Paneled carinated bowl with Redwine mode rim, Tallow Grove site (41NA231), Feature 45, Vessel No. 2. 


\section{Robert Griffin Site (41SY41)}

Five Caddo burials were excavated by Dr. J. H. Burr, a Biology professor at Stephen F. Austin State University, and his student, Paul Hancock, between 1960 and 1962 at the Robert Griffin site along the Attoyac Bayou in western Shelby County, Texas. Altogether 21 ceramic vessels and approximately 400 sherds were retained from this work. Burial 2 contained a male individual with an eight-pointed carved shell pendant over the chest, a pipe near the head, a four-cornered engraved bottle, and two carinated bowls, one being a finely made vessel with Redwine mode rim treatment (Figure 24).

\section{PROVENIENCE: Robert Griffin Site (41SY41) VESSEL NO.: Burial 2, Vessel 3}

NON-PLASTICS: grog and bone

VESSEL FORM: carinated bowl with a Redwine mode rim; the pie crust rim treatment is folded outward at a greater than right angle. Sixteen symmetrical peaks or lobes are present.

CORE COLOR: B, fired and cooled in a low oxygen environment.

INTERIOR SURFACE COLOR: 10YR3/1 (very dark gray)

EXTERIOR SURFACE COLOR: 10YR3/1 (very dark gray)

DISTAL RIM THICKNESS: $6.2 \mathrm{~mm}$

INTERIOR SURFACE TREATMENT: burnished

HEIGHT: $6.4 \mathrm{~cm} \quad$ HEIGHT OF RIM: $3.4 \mathrm{~cm}$

DIAMETER AT BOTTOM OF RIM: $12.5 \mathrm{~cm}$

WALL THICKNESS: $\quad 5.5 \mathrm{~mm}$

DISTAL RIM WIDTH: $18.5 \mathrm{~mm}$

EXTERIOR SURFACE TREATMENT: polished

ORIFICE DIAMETER: $14.0 \mathrm{~cm}$

ESTIMATED VOLUME: 0.66 liters

BASE DIAMETER: $7.1 \mathrm{~cm}$

DECORATION: Fine engraved lines with white kaolin pigment in some lines. There are four panels of horizontal interlocking scrolls (Thurmond 1990:Figure 6g); the central element of the scroll has a filler zone composed of vertical parallel fine engraved lines. Bi-concave columns filled with horizontal fine engraved lines separate the panels. Below the rim design at the shoulder are two parallel horizontal lines with vertical engraved line fillers. Under the pie crust rim treatment are vertical, parallel, fine engraved lines. This is a very finely made vessel both in structure and decoration. The four decorated panels are carefully arranged to conform to the 16 peaks on the Redwine mode rim.

TYPE: Burr Engraved (Middlebrook n.d.), defined as carinated bowls with either Redwine mode or Myers mode rims and engraved horizontal interlocking scrolls motifs found in Middle/Late Caddo period contexts in Shelby County and surrounding areas.

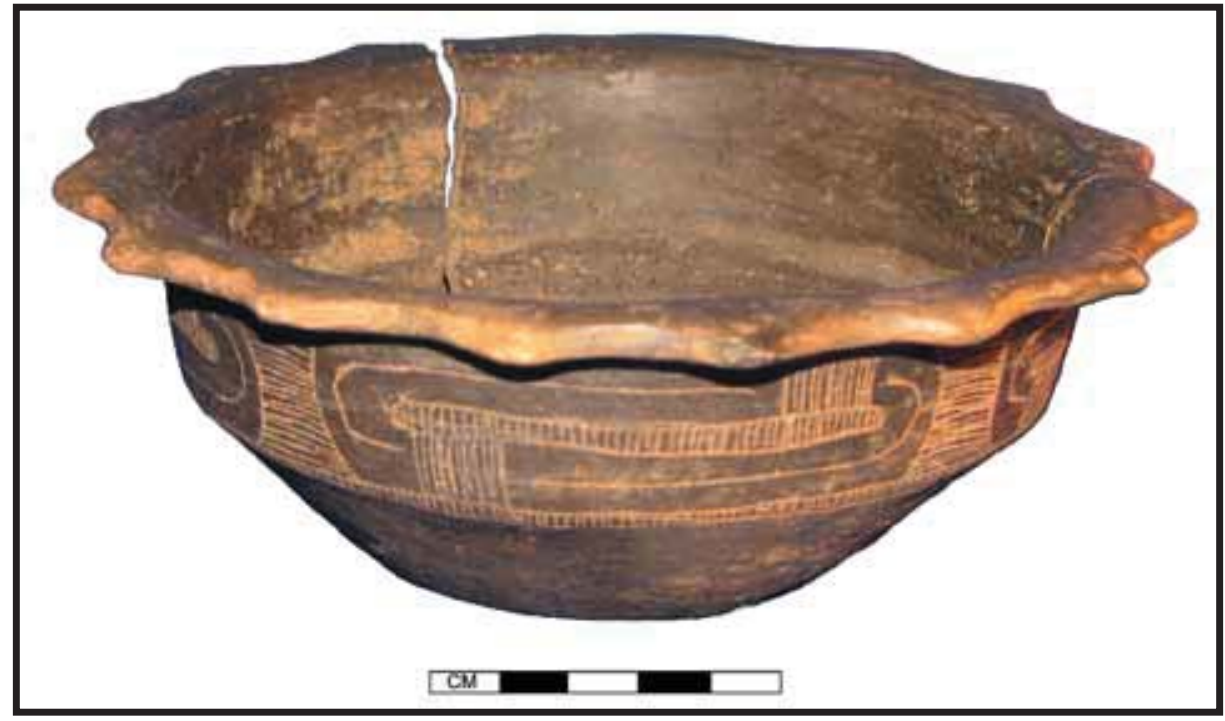

Figure 24. Engraved carinated bowl with Redwine mode rim, Robert Griffin site (41SY41), Burial 2, Vessel 3. 


\section{Buddy Hancock Site (41SY45)}

Five Caddo burials were excavated by Dr. J. H. Burr and others between 1965 and 1969 at the Buddy Hancock Site on Smith Creek in central Shelby County, Texas, about one mile north of the Morse Mound site (41SY27). Twenty-eight ceramic vessels were uncovered during this work along with 362 sherds excavated from a nearby midden. Altogether, seven vessels and three rim sherds had Redwine mode rim treatments.

VESSEL NO.: Burial 1, Vessel 2 (Figure 25)

NON-PLASTICS: grog and coarse bone

VESSEL FORM: Carinated bowl with a Redwine mode rim. Eleven peaks are evident on the rim, with shallow, nearly straight intervening segments.

CORE COLOR: I, incompletely-oxidized during firing, possible smudging/sooting

INTERIOR SURFACE COLOR: 5YR4/2 (dark reddish-gray)

EXTERIOR SURFACE COLOR: 5YR2.5/1 (black)

WALL THICKNESS: $\quad 5.5 \mathrm{~mm}$

DISTAL RIM WIDTH: $14.0 \mathrm{~mm}$

DISTAL RIM THICKNESS: $5.8 \mathrm{~mm}$

INTERIOR SURFACE TREATMENT: smoothed

EXTERIOR SURFACE TREATMENT: burnished

HEIGHT: $6.4 \mathrm{~cm}$

HEIGHT OF RIM: $3.2 \mathrm{~cm}$

ORIFICE DIAMETER: $17.0 \mathrm{~cm}$

DIAMETER AT BOTTOM OF RIM: $13.5 \mathrm{~cm}$

BASE DIAMETER: $8.4 \mathrm{~cm}$

ESTIMATED VOLUME: 0.91 liters

DECORATION: Three engraved panels of horizontal interlocking scrolls with panel partitions being bi-concave columns filled with horizontal lines. The central element of the scrolls is composed of three closely spaced horizontal lines with two offset hemi-columns (one above and one below the line); the hemi-columns are filled with horizontal lines. There are no crook-shaped lines around the ends of the central element as seen in other Burr Engraved examples from this site.

TYPE: Burr Engraved (Middlebrook n.d.)

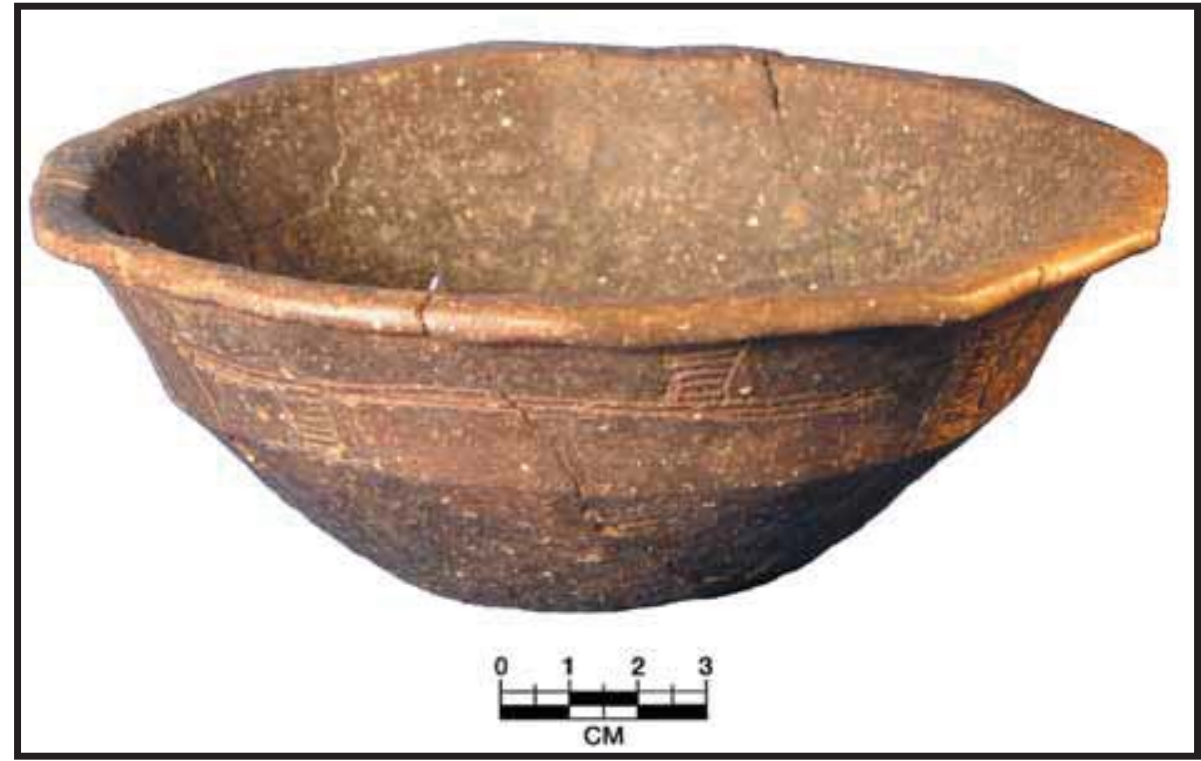

Figure 25. Burr Engraved (Middlebrook n.d.) carinated bowl with Redwine mode rim, Buddy Hancock site (41SY45), Burial 1, Vessel 2. 
VESSEL NO.: Burial 1, Vessel 3

NON-PLASTICS: grog and coarse bone

VESSEL FORM: carinated bowl with Redwine mode rim; approximately 24 peaks, but only 16 are very clear rim peaks

CORE COLOR: F, fired in reduced oxygen environment, cooled in open air

INTERIOR SURFACE COLOR: 10YR5/6 (red)

EXTERIOR SURFACE COLOR: 10YR4/4 (weak red)

WALL THICKNESS: $\quad 5.0 \mathrm{~mm}$

DISTAL RIM WIDTH: $8.1 \mathrm{~mm}$

DISTAL RIM THICKNESS: $4.1 \mathrm{~mm}$

INTERIOR SURFACE TREATMENT: smoothed

EXTERIOR SURFACE TREATMENT: burnished

HEIGHT: $5.15 \mathrm{~cm}$

HEIGHT OF RIM: $2.8 \mathrm{~cm}$

ORIFICE DIAMETER: $10.7 \mathrm{~cm}$

DIAMETER AT BOTTOM OF RIM: $8.5 \mathrm{~cm}$

BASE DIAMETER: $4.4 \mathrm{~cm}$

ESTIMATED VOLUME: 0.28 liters

DECORATION: horizontal interlocking engraved scrolls in three panels, but with no dividing elements. The central element of the scroll is a single horizontal engraved line with two offset bi-concave hemi-columns (one above and one below the central line). A crook-shaped line goes around each end of the central element. This is an unusual variant due to the small size of the peaks and the absence of dividers between the scroll panels. TYPE: Burr Engraved (Middlebrook n.d.) 
VESSEL NO.: Burial 1, Vessel 12 (Figure 26)

NON-PLASTICS: grog and coarse bone

VESSEL FORM: Carinated bowl with Redwine mode rim treatment; there are 11 subtle or gently rounded rim peaks.

CORE COLOR: F, fired in a reduced oxygen environment, and cooled in the open air.

INTERIOR SURFACE COLOR: 2.5YR4/4 (reddish-brown)

EXTERIOR SURFACE COLOR: 2.5YR5/6 (red)

WALL THICKNESS: $\quad 5.0 \mathrm{~mm}$

DISTAL RIM WIDTH: $12.9 \mathrm{~mm}$

DISTAL RIM THICKNESS: $6.2 \mathrm{~mm}$

INTERIOR SURFACE TREATMENT: smoothed

EXTERIOR SURFACE TREATMENT: burnished

HEIGHT: $4.9 \mathrm{~cm}$

HEIGHT OF RIM: $2.4 \mathrm{~cm}$

ORIFICE DIAMETER: $9.8 \mathrm{~cm}$

DIAMETER AT BOTTOM OF RIM: $8.5 \mathrm{~cm}$

BASE DIAMETER: $4.1 \mathrm{~cm}$

ESTIMATED VOLUME: 0.24 liters

DECORATION: The rim has nine vertical engraved columns composed of two to four closely parallel lines (resulting in some excised areas) and nine single vertical lines midway between the columns. The nine engraved segments do not conform to the 11 rim peaks.

TYPE: Undetermined engraved

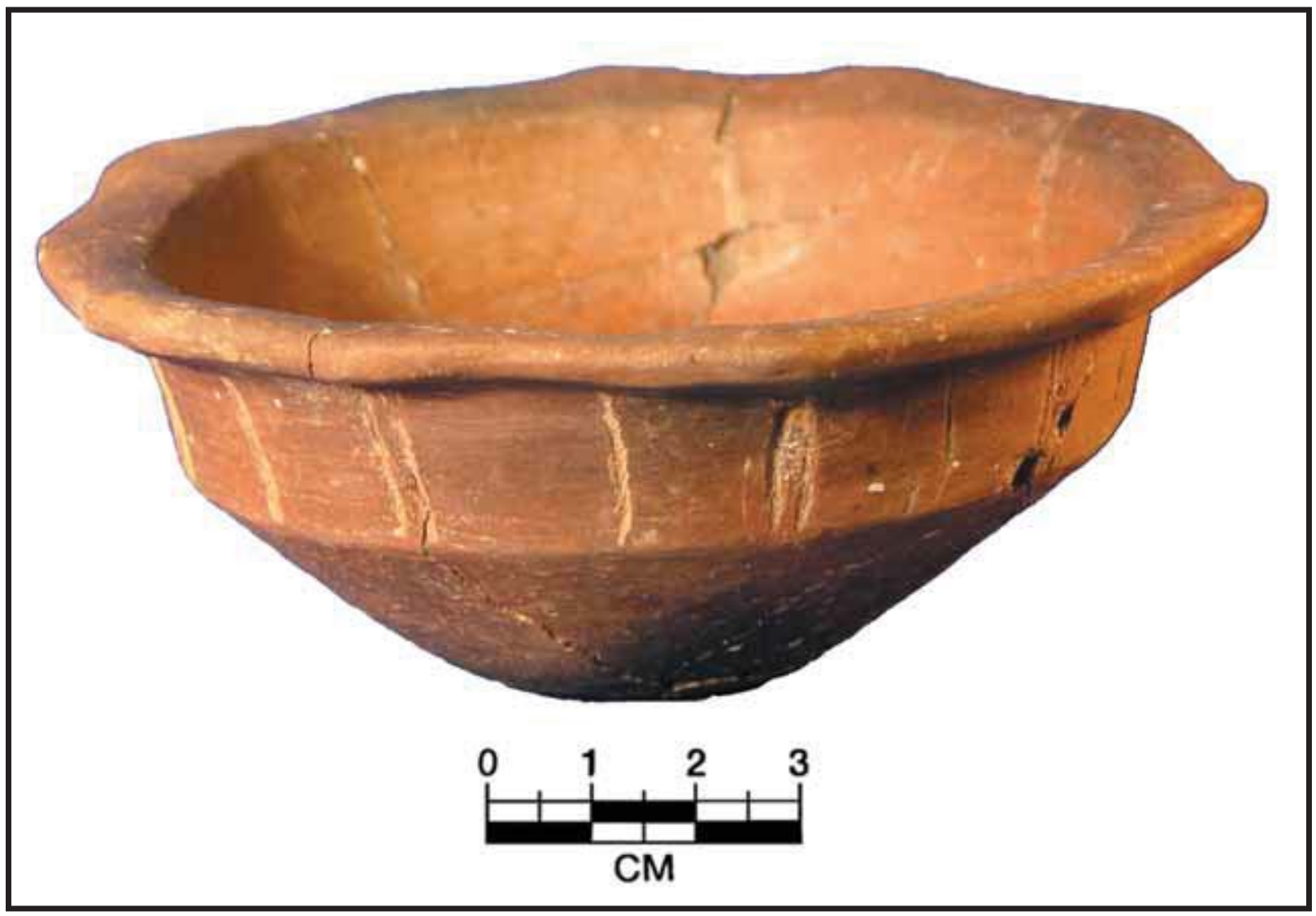

Figure 26. Buddy Hancock site, Burial 1, Vessel 12: engraved carinated bowl with Redwine mode rim. 
VESSEL NO.: Burial 1, Vessel 5 (Figure 27)

NON-PLASTICS: grog and coarse bone

VESSEL FORM: Carinated bowl with Redwine mode rim; 12 peaks. Rim treatment peaks are very softly rounded, often indistinct, and poorly shaped.

CORE COLOR: I, incompletely-oxidized during firing; possible smudging/sooting

INTERIOR SURFACE COLOR: 2.5YR5/3 (reddish-brown)

EXTERIOR SURFACE COLOR: 5YR4/1 (dark gray)

WALL THICKNESS: $\quad 4.5 \mathrm{~mm}$

DISTAL RIM WIDTH: $12 \mathrm{~mm} \quad$ DISTAL RIM THICKNESS: $6.8 \mathrm{~mm}$

INTERIOR SURFACE TREATMENT: smoothed

EXTERIOR SURFACE TREATMENT: burnished

HEIGHT: $9.9 \mathrm{~cm}$

HEIGHT OF RIM: $4.0 \mathrm{~cm}$

ORIFICE DIAMETER: $19.7 \mathrm{~cm}$

DIAMETER AT BOTTOM OF RIM: $17.0 \mathrm{~cm}$

BASE DIAMETER: $7.3 \mathrm{~cm}$

ESTIMATED VOLUME: 1.8 liters

DECORATION: Six panels of engraved (three or four closely parallel) lines forming rectilinear coverings of a short central hemi-column; panels alternate in polarity (they are opened up and down) and are separated by single engraved lines. The engraved design is crudely made.

TYPE: Undetermined engraved, but the motif may be an example of the reduction of Tyson Engraved (Middlebrook 1993).

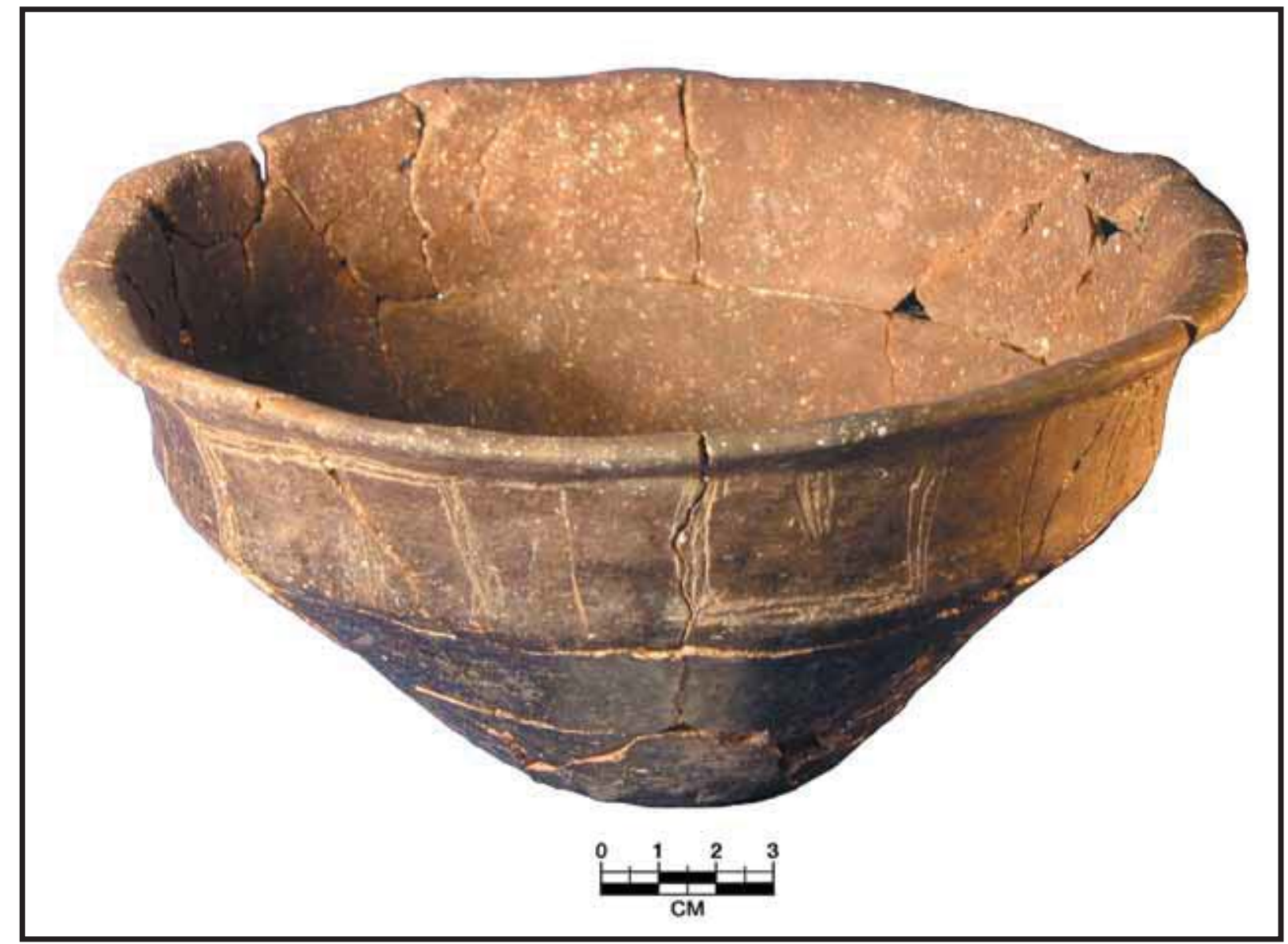

Figure 27. Carinated bowl from the Buddy Hancock site with untyped engraved element and Redwine mode rim. 
VESSEL NO.: Burial 4, Vessel 3 (Figure 28)

NON-PLASTICS: grog and bone

VESSEL FORM: carinated bowl with Redwine mode rim; 16 peaks.

CORE COLOR: F, fired in reduced oxygen environment, cooled in open air

INTERIOR SURFACE COLOR: 2.5YR5/4 (reddish-brown)

EXTERIOR SURFACE COLOR: 2.5YR5/4 (reddish-brown), fire clouding

WALL THICKNESS: $\quad 5.9 \mathrm{~mm}$

DISTAL RIM WIDTH: $15.6 \mathrm{~mm}$

DISTAL RIM THICKNESS: $7.0 \mathrm{~mm}$

INTERIOR SURFACE TREATMENT: burnished; a black organic residue noted on the interior of the vessel.

EXTERIOR SURFACE TREATMENT: burnished

HEIGHT: $9.5 \mathrm{~cm}$

HEIGHT OF RIM: $4.5 \mathrm{~cm}$

ORIFICE DIAMETER: $18.5 \mathrm{~cm}$

DIAMETER AT BOTTOM OF RIM: $15 \mathrm{~cm}$

BASE DIAMETER: $8.0 \mathrm{~cm}$

ESTIMATED VOLUME: 1.44 liters

DECORATION: Three panels of horizontal interlocking scrolls separated with bi-concave columns filled with horizontal lines. The central element of the scroll consists of a horizontal triple engraved line with two off set bi-concave hemi-columns (one above and one below the central line) filled with horizontal lines. The hemicolumn is in a downward direction on the left end of the centerline. A crook-shaped line goes around the end of the central element.

TYPE: Burr Engraved (Middlebrook n.d.)

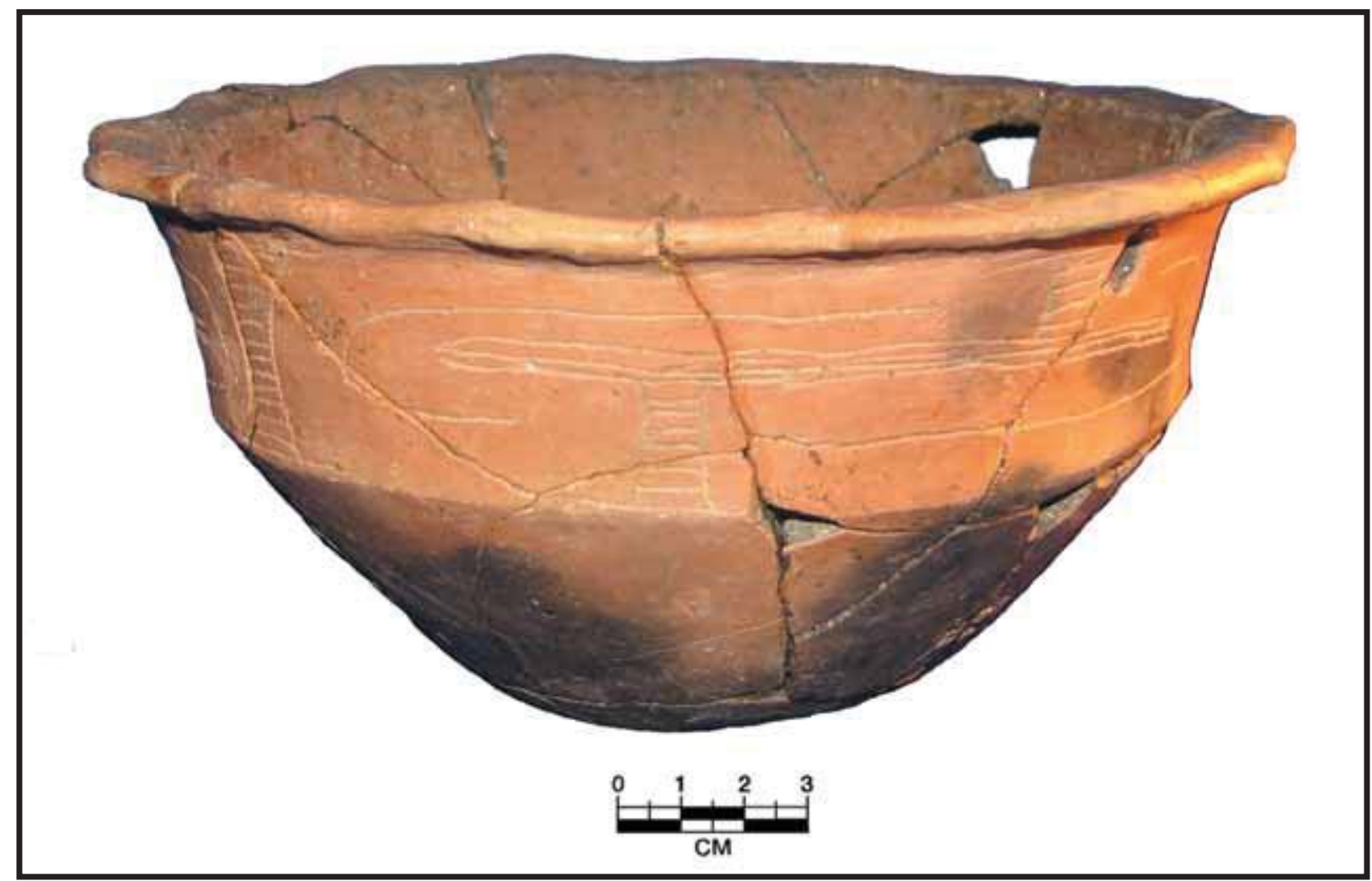

Figure 28. Carinated bowl with horizontal interlocking scroll design and Redwine mode rim, Buddy Hancock site, Burial 4, Vessel 3. 
VESSEL NO.: Burial 4, Vessel 4

NON-PLASTICS: grog and coarse bone

VESSEL FORM: carinated bowl with Redwine mode rim; seven to eight peaks were originally present; only three peaks are very clear.

CORE COLOR: F, fired in a reduced oxygen environment, and cooled in the open air

INTERIOR SURFACE COLOR: 2.5YR5/4 (reddish-brown)

EXTERIOR SURFACE COLOR: 10R4/1 (dark reddish-gray)

WALL THICKNESS: $\quad 4.0 \mathrm{~mm}$

DISTAL RIM WIDTH: $6.7 \mathrm{~mm}$

DISTAL RIM THICKNESS: $3.2 \mathrm{~mm}$

INTERIOR SURFACE TREATMENT: smoothed

EXTERIOR SURFACE TREATMENT: burnished

HEIGHT: $4.3 \mathrm{~cm}$

HEIGHT OF RIM: $2.1 \mathrm{~cm}$

ORIFICE DIAMETER: $9.0 \mathrm{~cm}$

DIAMETER AT BOTTOM OF RIM: $7.5 \mathrm{~cm}$

BASE DIAMETER: $3.7 \mathrm{~cm}$

ESTIMATED VOLUME: 0.14 liters

DECORATION: plain

TYPE: undetermined plain vessel

NOTES: Rim broken and/or eroded for about two-thirds of the vessel circumference.

VESSEL NO.: Burial 5, Vessel 2 (partial vessel)

NON-PLASTICS: grog and fine bone

VESSEL FORM: carinated bowl with a Redwine mode rim

CORE COLOR: F, fired in a reducing environment and cooled in the open air

INTERIOR SURFACE COLOR: 2.5YR4/3 (reddish-brown)

EXTERIOR SURFACE COLOR: 2.5YR5/6 (red)

WALL THICKNESS: $\quad 6.0 \mathrm{~mm}$

DISTAL RIM WIDTH: $12.5 \mathrm{~mm}$

DISTAL RIM THICKNESS: $6.1 \mathrm{~mm}$

INTERIOR SURFACE TREATMENT: burnished

EXTERIOR SURFACE TREATMENT: burnished

HEIGHT: $5.3 \mathrm{~cm}$

HEIGHT OF RIM: $3.0 \mathrm{~cm}$

ORIFICE DIAMETER: approximately $11-12 \mathrm{~cm}$

DIAMETER AT BOTTOM OF RIM: $9.0 \mathrm{~cm}$

BASE DIAMETER: approximately $6.0 \mathrm{~cm}$

DECORATION: plain

TYPE: Undetermined plain vessel

NOTES: Partial vessel; approximately $33 \%$ of the vessel is present (14 sherds); three sherds are conjoined to form a large section of the rim and body with a small section of the base. 
PROVENIENCE: 41SY45, "surface/shovel test"

VESSEL NO.: Rim Sherd

NON-PLASTICS: grog

VESSEL FORM: undetermined; possible carinated bowl; Redwine mode rim present, and a single rim peak.

CORE COLOR: A, fired and cooled in the open air

INTERIOR SURFACE COLOR: 5YR5/4 (reddish-brown)

EXTERIOR SURFACE COLOR: 2.5YR5/4 (reddish-brown)

WALL THICKNESS: $\quad 6.5 \mathrm{~mm}$

DISTAL RIM WIDTH: $8.0 \mathrm{~mm}$

DISTAL RIM THICKNESS: $7.1 \mathrm{~mm}$

INTERIOR SURFACE TREATMENT: smoothed

EXTERIOR SURFACE TREATMENT: burnished

HEIGHT: undetermined

ORIFICE DIAMETER: approximately $20-22 \mathrm{~cm}$

DIAMETER AT BOTTOM OF RIM: undetermined

BASE DIAMETER: undetermined

ESTIMATED VOLUME: undetermined

DECORATION: none visible

TYPE: undetermined

PROVENIENCE: 41SY45, "surface/shovel test"

VESSEL NO.: Rim sherd

NON-PLASTICS: coarse bone and grog

VESSEL FORM: Undetermined, possible carinated bowl; has Redwine mode rim

CORE COLOR: F, fired in a low oxygen environment and cooled in the open air

INTERIOR SURFACE COLOR: 10R5/4 (weak red)

EXTERIOR SURFACE COLOR: 10R5/4 (weak red)

WALL THICKNESS: $\quad 4.5 \mathrm{~mm}$

DISTAL RIM WIDTH: $15.2 \mathrm{~mm}$

DISTAL RIM THICKNESS: $7.1 \mathrm{~mm}$

INTERIOR SURFACE TREATMENT: smoothed

EXTERIOR SURFACE TREATMENT: smoothed

HEIGHT: undetermined

ORIFICE DIAMETER: approximately $20 \mathrm{~cm}$

DIAMETER AT BOTTOM OF RIM: undetermined

BASE DIAMETER: undetermined

ESTIMATED VOLUME: undetermined

DECORATION: Parallel diagonal incised lines are present under the rim treatment. A single engraved horizontal line is present about $0.5 \mathrm{~cm}$ below rim treatment; this line may be part of a horizontal interlocking scroll.

TYPE: undetermined 
PROVENIENCE: 41SY45, "surface/shovel test" (Figure 29)

VESSEL NO.: Rim Sherd

NON-PLASTICS: grog

VESSEL FORM: undetermined, possible carinated bowl; Redwine mode rim present.

CORE COLOR: B, fired and cooled in a low oxygen environment

INTERIOR SURFACE COLOR: 7.5YR4/2 (dark brown)

EXTERIOR SURFACE COLOR: 7.5YR5/3 (brown)

WALL THICKNESS: $\quad 4.6 \mathrm{~mm}$

DISTAL RIM WIDTH: $0.95 \mathrm{~mm}$

DISTAL RIM THICKNESS: $3.3 \mathrm{~mm}$

INTERIOR SURFACE TREATMENT: smoothed

EXTERIOR SURFACE TREATMENT: smoothed/burnished

HEIGHT: undetermined

ORIFICE DIAMETER: approximately $18 \mathrm{~cm}$

DIAMETER AT BOTTOM OF RIM: undetermined

BASE DIAMETER: undetermined

ESTIMATED VOLUME: undetermined

DECORATION: Portion of the mid-section of an engraved scroll; triangular spaces above and below this scroll section have fillers of cross-hatched bi-concave pillars outlining negative circles. This is an unusual scroll design for a Redwine mode vessel at this site.

TYPE: Undetermined

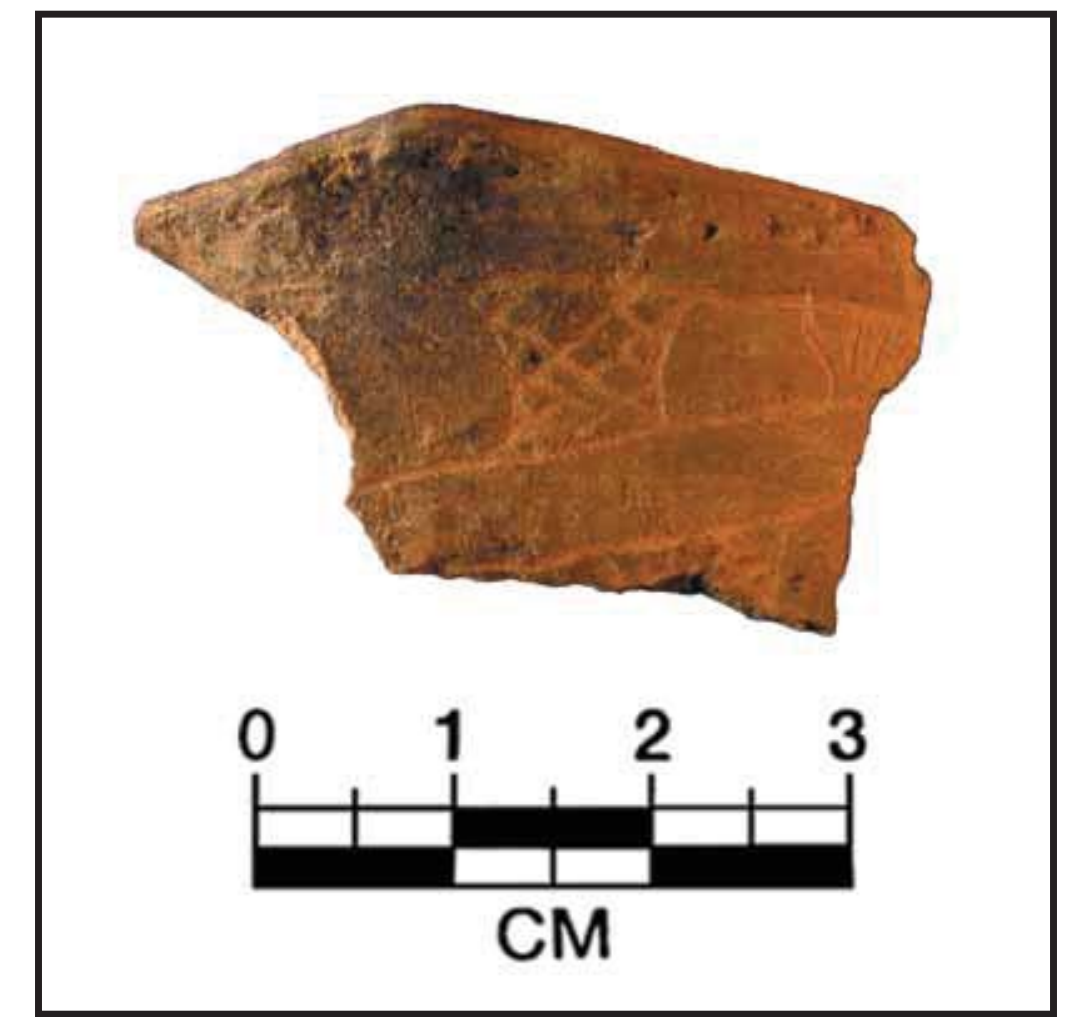

Figure 29. Engraved rim sherd with Redwine mode rim, Buddy Hancock site, "surface/shovel test." 


\section{Three isolated Redwine mode examples from Arkansas}

\section{Bowman Site (3LR46/3LR50)}

At Southern Arkansas University (SAU) in Magnolia, Arkansas, there is a collection of vessels with rims with the Redwine rim mode. Nine are from the Bowman site (3LR46/3LR50), a large and relatively unknown Caddo mound site located on the Red River and Choctaw Bayou west of Texarkana. The site is divided into several residential and ceremonial areas, hence the different site numbers. There are no radiocarbon dates from Bowman but ceramics such as Holly Fine Engraved, Hickory Fine Engraved, and Weches Fingernail Impressed indicate that an Early Caddo period (ca. A.D. 1000-1200) occupation is present, but it is unknown during what other periods the site may have been occupied.

Examples 1-8 from the Bowman site are vessel forms Frank Schambach has termed "elephant foot" because of their unusual shape. Apart from having Redwine mode rims, the unusual vessels also have lobed bases much in the same fashion as the lobed rims. Some also had leg-like appendages below the base; suspension holes were also a common trait.

These vessels are described as follows:

1. From the Spenser collection (3LR46). A plain bowl with suspension holes (Figure 30).

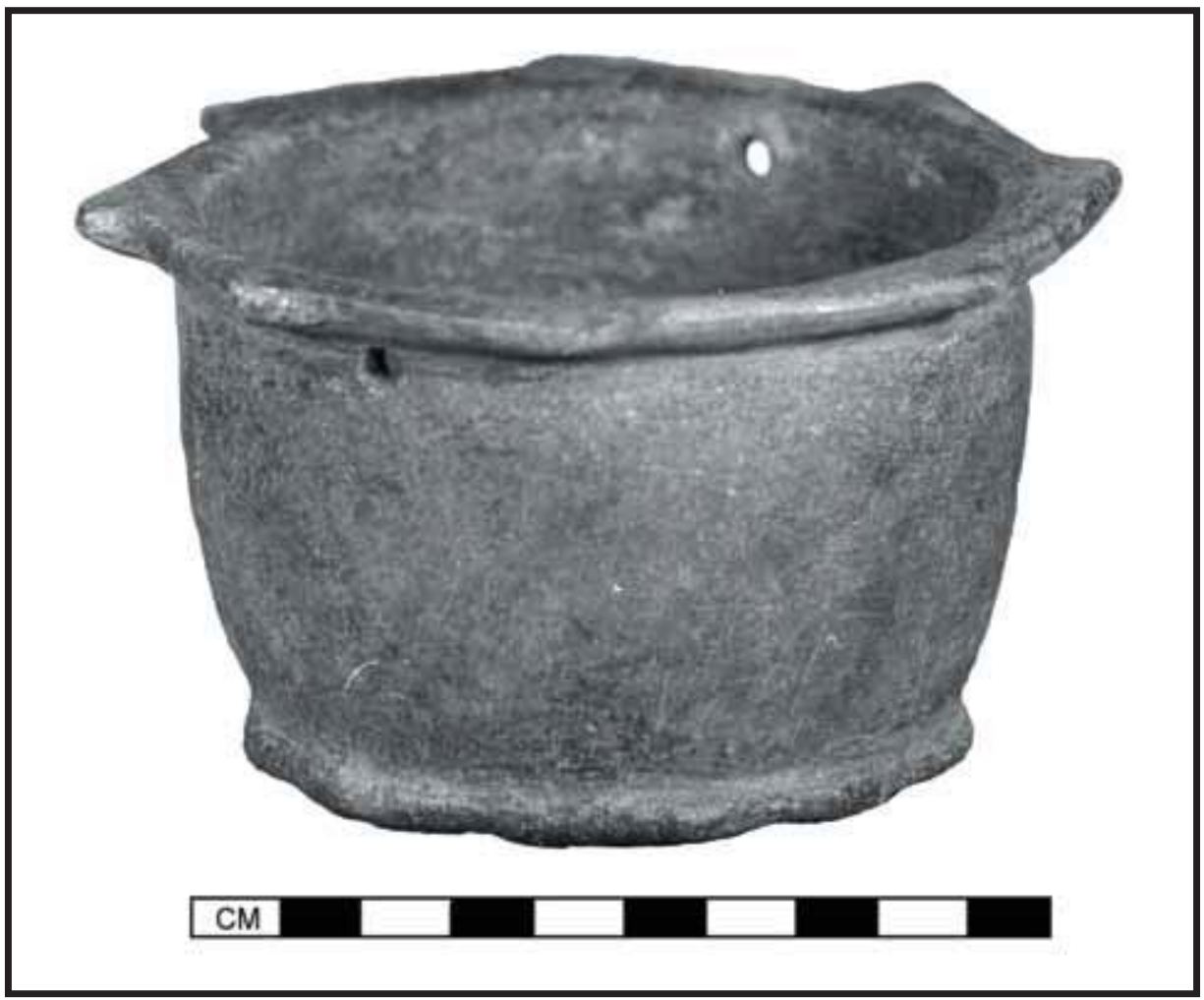

Figure 30. Plain jar from Spenser collection from the Bowman site (3LR46) with Redwine mode rim. 
2. Chance collection (3LR46). This jar has rows of horizontal incised lines below the rim with punctates on the lower portion of the vessel. There is a row on nodes around the middle of the vessel. This vessel also has leg-like appendages extending from the base (Figure 31).

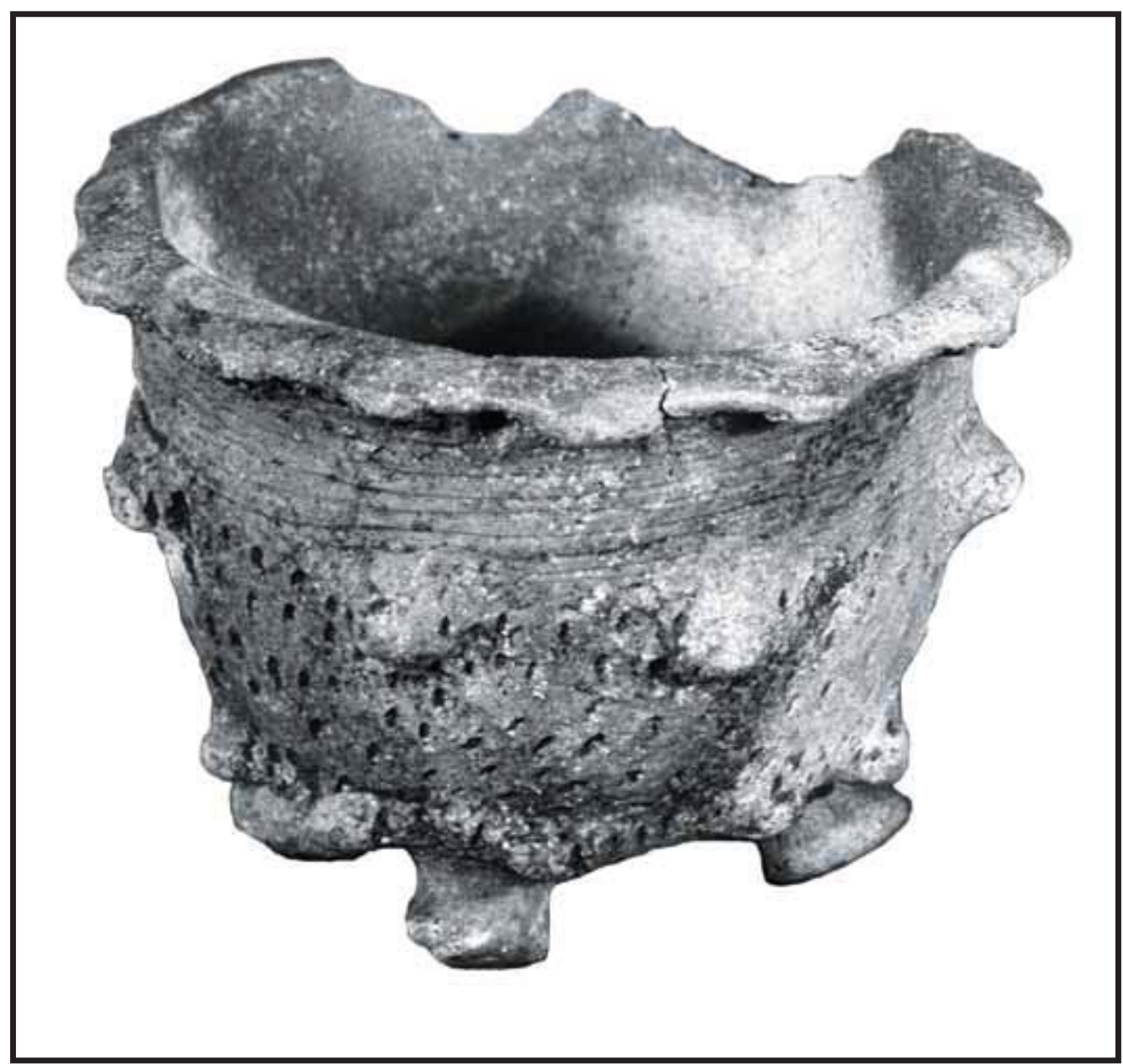

Figure 31. Incised and punctuated jar with Redwine mode rim from the Chance Collection from the Bowman site (3LR46). 
3. Shurtleff collection (3LR50). From Mound 2, Burial 5. The decoration on this vessel consists of horizontal incised lines with a ring of nodes around the middle of the vessel.

4. Shurtleff collection (3LR50). Mound 2, Burial 1. The vessel is decorated with horizontal rows of incised lines. It also has suspension holes.

5. Shurtleff collection (3LR50). Mound 2, Burial 1. Horizontal and vertical rows of incised lines decorate this vessel. The vessel also has suspension holes.

6. Shurtleff collection (3LR50). Decoration on this "elephant foot" vessel consists of random instrument punctates; there are also suspension holes.

7. Shurtleff collection (3LR50). Mound 2, Burial 5. This vessel is decorated with rows of diagonal incised lines with a row of nodes and punctates around the middle of the vessel.

8. Shurtliff collection (3LR50). Mound 2, Burial 5. This vessel had two opposing suspension holes through the flattened rim and nodes on the exterior body wall. Decoration was rows of tool punctuates (Figure 32).

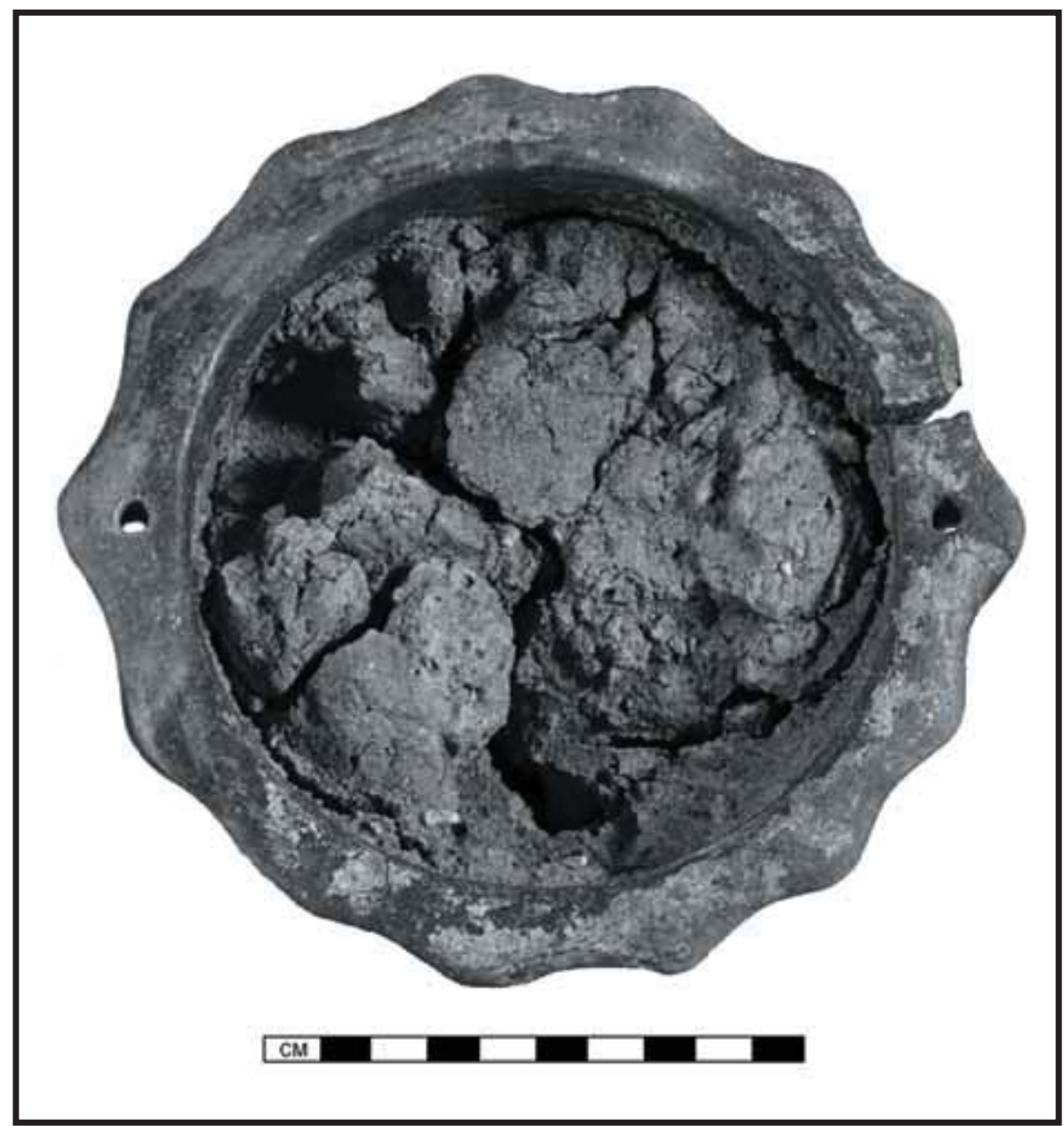

Figure 32. Top view of Redwine mode rim from the Shurtleff Collection at the Bowman site (3LR50). 
The ninth vessel from the Bowman site (3LR50) is a partial vessel with a complete Redwine mode rim. The rim is flattened and articulated at a right angle from the body of the vessel, and has 25 evenly spaced lobes. The vessel decoration is excised triangles on top of each lobe with engraved lines between each node. The shape of the vessel and the excised triangles on the top of the flattened rim surface compare with an example of Holly Fine Engraved illustrated by Suhm and Jelks (1962:Plate 39g).

\section{Clark Site (3AS154) and 3HE35}

Other examples of Redwine mode rims in the SAU collections include two other vessels: (1) Clark site (3AS154), White collection, Vessel 20. This is an incised bowl with the Redwine mode rim and also a lobed base; and (2) Museum of the American Indian Collection (3HE35). This bowl is decorated with random instrument punctuates and has a row of nodes around the middle of the vessel. It also has suspension holes (Figure 33).

Finally, there is a possible Redwine mode rim example on a carinated bowl with an engraved rectangular scroll design in "Art of the Ancient Caddo" (Bonds 2006:Figure 326). Unfortunately no provenience is listed for this example, although it is probable that the vessel came from a Caddo site in southwestern Arkansas.

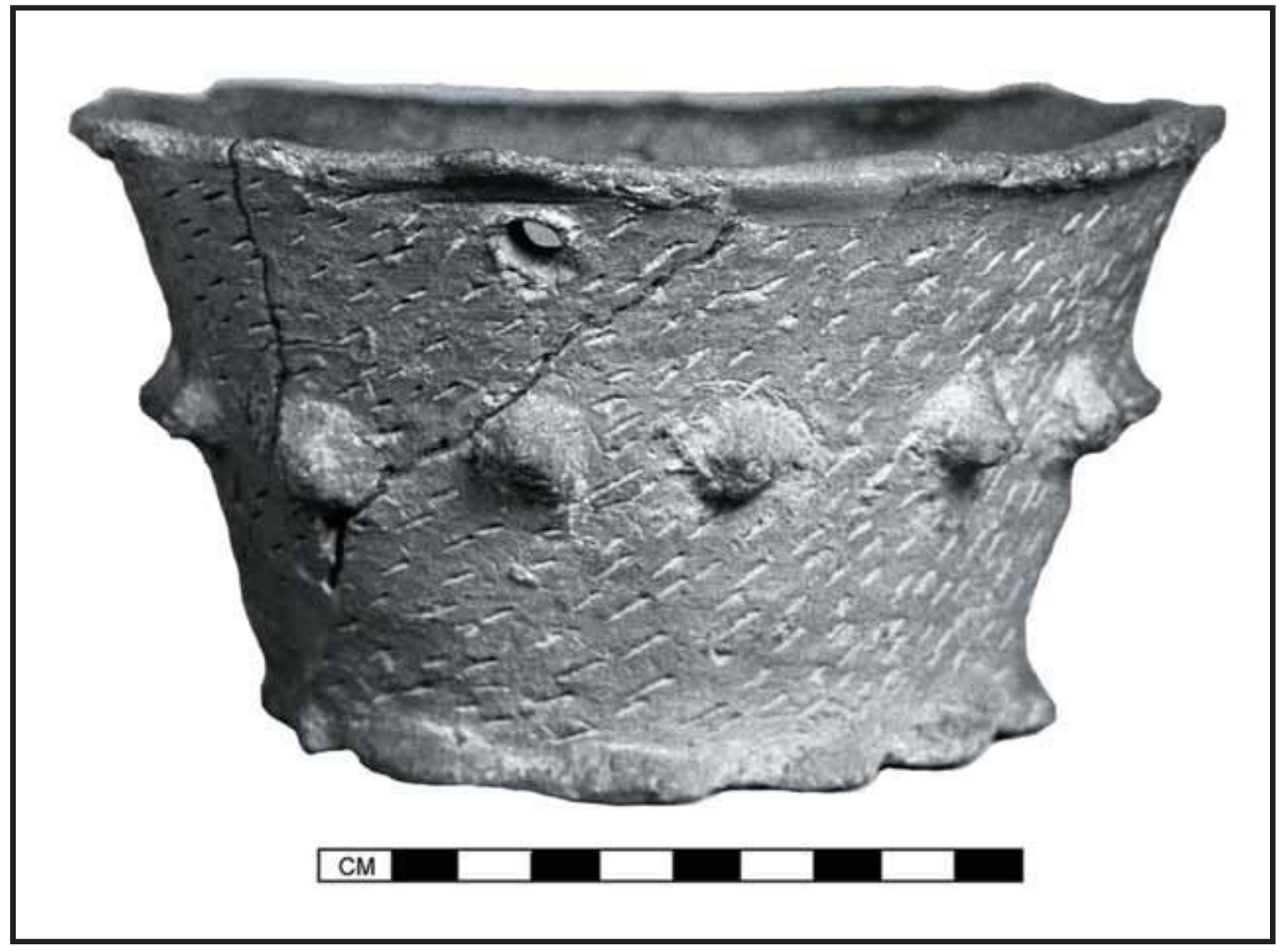

Figure 33. Jar with Redwine mode rim from the M. R. Harrington Collection (3LR35). 


\section{Myers or Sprocket Rim Mode Vessels}

The Myers mode rim form is another unique rim form that is primarily restricted to vessels from a cluster of sites in the Great Bend and Little Missouri regions of southwestern Arkansas (see Figure 5). Myers mode rim vessels also occur on isolated Caddo sites in eastern Texas (Table 2). Myers mode rim vessels appear to date from the Middle Caddo period as well as the early part of the Late Caddo period (A.D. 1400-1500).

Table 2. Sites with Myers mode rims and number of examples.

\begin{tabular}{llll}
\hline Site & No. & Site & No. \\
\hline 3MI139 & 1 & 41 UR315 & 1 \\
3H01 & 2 & McDaniel & 1 \\
41SM193 & 2 & Hollywood Creek & 1 \\
41RR77 & 2 & Clark Co., Arkansas & 1 \\
41NA49 & 2 & Bowie Co., Texas & 1 \\
41SY45 & 1 & & \\
3HE35 & 1 & & \\
& & & \\
\hline
\end{tabular}

The Myers mode rim form was identified on certain Myers Engraved vessels, a new pottery type identified during analysis of ceramics from the Middle Caddo Myers site (3M139) in southwestern Arkansas. Based on a single sherd (Class 55) (Miller 1986:95) of this undefined type from the Myers site and 12 additional specimens from other sites, the new type, Myers Engraved was identified. Myers Engraved is described as having two widely spaced horizontal engraved lines on the upper portion of the rim, and on the lower portion of the rim there is a single meandering line of small tool punctates, often slightly smoothed over by polishing. There are two lip treatments, one gently rounded and flush with the rim; the other cogged or sprocketed. John Miller (1986:97) described the later rim treatment as "cogged or sprocketed lips or rims which consisted of a series of triangular cogs which radiate outward at almost right angles to the rim." In certain instances, the short arm of the triangles appear to have cut edges to shape them, probably done when the vessel was in a leather-hard stage prior to firing. Since the lip was missing from the Myers Engraved sherd identified at the Myers site, it was not conclusive if it had a sprocket rim. However, Miller (1986:94) illustrated an un-typed sprocket rim sherd with a horizontal engraved line (Class 54).

\section{Great Bend and Little Missouri regions}

Certain varieties of Handy Engraved and Haley Engraved carinated bowls in the Great Bend and Little Missouri regions of southwestern Arkansas have Myers mode rims. This includes vessels from the Haley, Washington, and Mineral Springs sites.

Myers mode rim vessels are known from the Haley site (3MI1). One example is a Myers Engraved bowl from Cemetery 2, Field Burial 26 (Miller 1986:Figure 15b). A second example from the same burial is an untyped sprocket-rimmed bowl (Miller 1986:Figure 16b). This large vessel had an engraved line around the flattened rim. These vessels were found in association with Crockett Curvilinear-Incised, Hickory Fine Engraved, Pease Brushed-Incised, Moore Noded, Handy Engraved, and a Haley variety Red River style pipe. Also from the Haley site (Shurtleff Collection) there are two Myers mode rim examples: one is a Myers Engraved bowl and the second a plain is untyped bowl (Miller 1986:Figures 19a-c). 
There is an example of the Myers Mode from the Washington site (3HE35) (Miller 1986:Figures 16b, 19a, and 22; Moore 1912:Figure 50). This and similar vessels are part of the Caddo collections gathered by Harrington (1920) on Ozan Creek in southwestern Arkansas, and were at the American Museum of Natural History (Gonzalez et al. 2005:Figures 6.5, A3.17, and A3.27) until they were recently repatriated to the Caddo Nation of Oklahoma.

There are also at least two examples of Myers mode rims from the Mineral Springs site (3HO1) (Bohannon 1973). Mineral Springs is a large and complex multiple-mound site whose most intensive use of the site seems to have occurred during the Middle Caddo Haley phase. The first vessel is a Handy Engraved bowl (Bohannon 1973:Figure 10e) from Burial 9, a multiple burial with numerous artifacts including vessels of Glassell Engraved, Friendship Engraved, Haley Complicated-Incised, Haley Engraved, Pease Brushed-Incised, and Hempstead Engraved. The second Myers mode rim vessel came from Burial 10 and was described as a Hodges Engraved bowl (Bohannon 1973:Figure 13p). From the report, the bowl appears to have a slanted scroll design with central circle elements. However, a bottle from Burial 10, is also described as Hodges Engraved but more closely resembles Bailey Engraved (Bohannon 1973:Figure13o). Other associated items in Burial 10 include Haley Engraved and Haley Complicated-Incised, Pease Brushed Incised, Maddox Engraved, Handy Engraved, Glassell Engraved, Avery Engraved, and Red River var. Haley pipes. These ceramic types in this burial are not typically associated with the later Hodges Engraved or Bailey Engraved types, but taken together would suggest a Middle Caddo occupation or one that lasted until ca. A.D. 1400-1500.

\section{Boyce Smith Collection, Troup, Texas}

In the Boyce Smith collection (Perttula et al. 2009b) there are two vessels with Myers mode rims from southwestern Arkansas. Site-specific provenience information is not available, but both are from Caddo sites in Clark County.

SITE NAME OR SITE NUMBER: Clark County, Arkansas

VESSEL NO.: 59

NON-PLASTICS: grog

VESSEL FORM: carinated bowl with Myers mode rim (four sprockets)

RIM AND LIP FORM: direct/rounded

CORE COLOR: B (fired and cooled in a reducing environment)

INTERIOR SURFACE COLOR: undetermined

EXTERIOR SURFACE COLOR: undetermined

WALL THICKNESS (RIM, BODY, AND BASE IN MM): rim, $4.9 \mathrm{~cm}$

INTERIOR SURFACE TREATMENT: burnished on rim, smoothed on body

EXTERIOR SURFACE TREATMENT: burnished

HEIGHT: $6.0 \mathrm{~cm}$

ORIFICE DIAMETER: $19.5 \mathrm{~cm}$

DIAMETER AT BOTTOM OF RIM OR NECK: $20.5 \mathrm{~cm}$

BASE DIAMETER: rounding

DECORATION: It has an engraved design that is repeated four times around the vessel, with red pigment in lines. The design consists of a hooked-arm motif with alternating triangles filled with hatching or crosshatching.

TYPE: undetermined 
SITE NAME OR SITE NUMBER: Hollywood Creek, Clark County, Arkansas (Figure 34a-b)

VESSEL NO.: 146

NON-PLASTICS: grog

VESSEL FORM: carinated bowl with Myers mode rim (four sprockets)

RIM AND LIP FORM: direct/rounded, exterior folded

CORE COLOR: undetermined

INTERIOR SURFACE COLOR: undetermined

EXTERIOR SURFACE COLOR: undetermined

WALL THICKNESS (RIM, BODY, AND BASE IN MM): rim, $5.6 \mathrm{~cm}$

INTERIOR SURFACE TREATMENT: smoothed

EXTERIOR SURFACE TREATMENT: smoothed

HEIGHT: $6.0 \mathrm{~cm}$

ORIFICE DIAMETER: $19.0 \mathrm{~cm}$

DIAMETER AT BOTTOM OF RIM OR NECK: $20.0 \mathrm{~cm}$

BASE DIAMETER: rounding

DECORATION: rectangular panels repeated four times, with ticked line running horizontally through the blank spaces of the panel. The central circular element with tick marks is repeated four times, once under each sprocket.

TYPE: Glassell Engraved
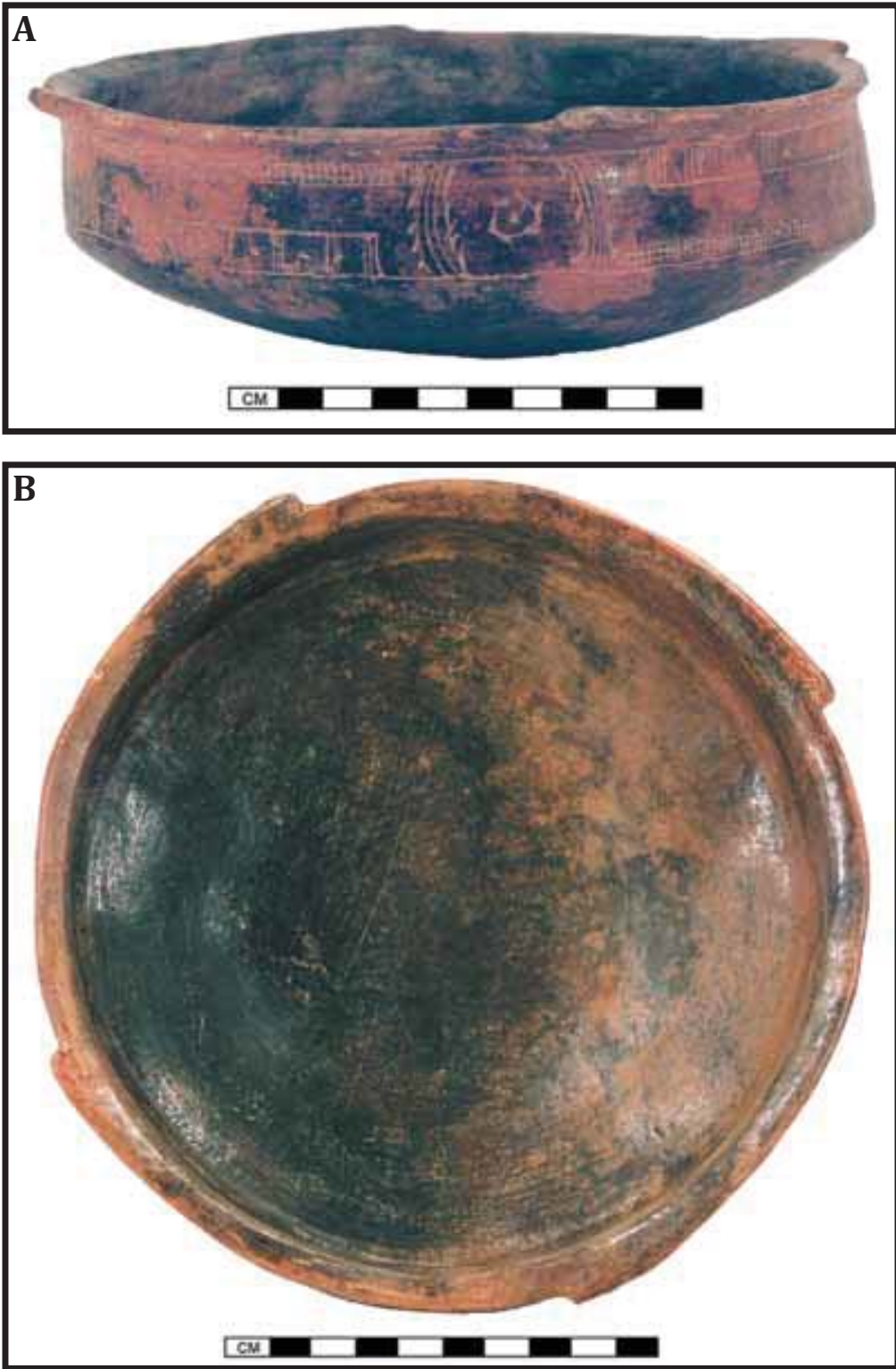

Figure 34. Engraved carinated bowl with Myers mode rim, Hollywood Creek, Clark County, Arkansas: a, side view; b, top view 


\section{Bowie County, Texas}

In the Boyce Smith collection (Perttula et al. 2009b) there is one vessel with a Myers mode rim from Bowie County, Texas (Figure 35a-b).

SITE NAME OR SITE NUMBER: Bowie County, Texas

VESSEL NO.: 128

NON-PLASTICS: grog VESSEL FORM: carinated bowl with Myers mode rim (16 sprockets)

RIM AND LIP FORM: direct rim and a rounded, exterior folded lip

CORE COLOR: B (fired and cooled in a reducing environment)

INTERIOR SURFACE COLOR: undetermined

EXTERIOR SURFACE COLOR: undetermined

WALL THICKNESS (RIM, BODY, AND BASE IN MM): rim, $9.3 \mathrm{~cm}$

INTERIOR SURFACE TREATMENT: smoothed on rim

EXTERIOR SURFACE TREATMENT: smoothed

HEIGHT: $16.4 \mathrm{~cm}$

ORIFICE DIAMETER: $33.6 \mathrm{~cm}$

DIAMETER AT BOTTOM OF RIM OR NECK: $33.5 \mathrm{~cm}$

BASE DIAMETER: 14.5

DECORATION: The upper part of the rim has two widely-spaced horizontal engraved lines. Below those are 16 alternating engraved semi-circles, separated by a row of punctations.

TYPE: undetermined
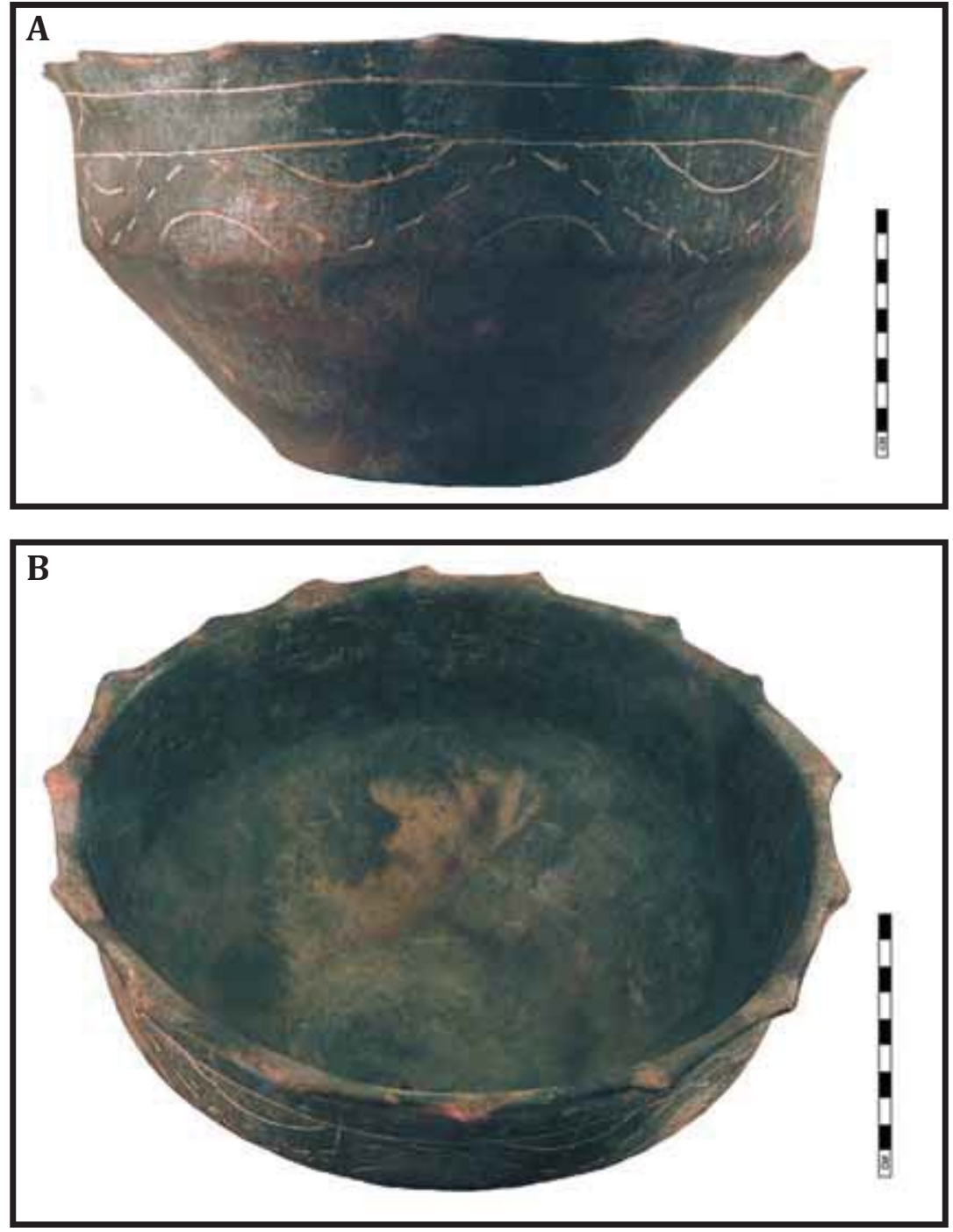

Figure 35. Myers mode rim, Bowie County, Texas: a, side view; b, top view. 


\section{Rowland Clark site (41RR77)}

Perino (1994:29 and Figure 13f) identifies Myers mode rims on several Clark Engraved bowls from the Rowland Clark site (41RR77) on the Red River. These occur in early McCurtain phase contexts (ca. A.D. 1300-1500). He describes these vessels as follows: "bowls frequently have four small and outward projecting sprocket-like lugs on the vessel rim; the sprocket-like lugs slant from the top of the sprocket to the base of the adjoining sprocket. Some Clark Engraved bowls have small, flattened lugs on the rim, and others have an extra sprocketed rim."

\section{Eastern Texas}

There are at present at least three known sites scattered across eastern Texas with examples of vessels with Myers mode rims (see Figure 5). Two of those sites, Redwine and Buddy Hancock, have examples of both Myers and Redwine mode vessels in the same burial context. This would seem to indicate that the two distinctive modes were in use at the same time, although the distribution of the two mode forms demonstrates that Caddo potters in different regions had different and very distinct ideas on vessel rim treatment that were made evident on their pottery. Furthermore, while the two modes had distinct boundaries in the Caddo area, vessels with these two modes in the same burial features at two sites is direct evidence of inter-regional contact.

\section{Redwine Myers Mode Rim Vessel 1 (Walters and Haskins 1998:Figure 13e) (Figure 36)}

SITE NAME OR SITE NUMBER: Redwine (41SM193)

VESSEL NO.: Burial 3

NON-PLASTICS: grog

VESSEL FORM: carinated bowl

RIM AND LIP FORM: direct, rounded with Myers mode rim with 20 sprockets

CORE COLOR: F, fired in reduced oxygen environment, cooled in open air

INTERIOR SURFACE COLOR: 10YR5/2 (grayish-brown) Fire clouding on rim, body, and the base.

EXTERIOR SURFACE COLOR: 10YR4/2 (dark grayish-brown) Fire clouding on the rim, body, and the base.

WALL THICKNESS (RIM, BODY, AND BASE IN MM): rim, 4.5

INTERIOR SURFACE TREATMENT: burnished on rim, body smoothed

EXTERIOR SURFACE TREATMENT: burnished

HEIGHT: $5.5 \mathrm{~cm}$

ORIFICE DIAMETER: $20.0 \mathrm{~cm}$

DIAMETER AT BOTTOM OF RIM OR NECK: $17.0 \mathrm{~cm}$

BASE DIAMETER: $18 \mathrm{~cm}$, rounded

DECORATION: Engraved continuous scroll filled with tool punctates, repeated five times around the vessel. The corners of the upper and lower scroll fill zone are filled with concentric circles and cross-hatching. There is a white pigment in the lines. The design element also resembles Nacogdoches Engraved (Hart 1982:46-63). TYPE: cf. Handy Engraved

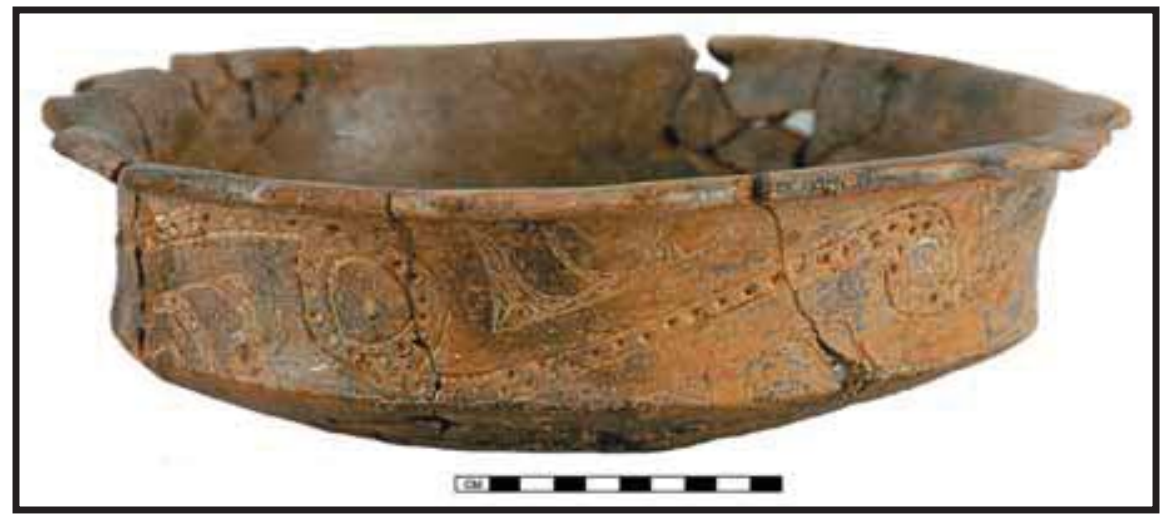

Figure 36. Handy Engraved vessel with Myers mode rim, the Redwine site. 
Redwine Myers Mode Rim Vessel 2 (Walters and Haskins 1998:Figure 11e) (Figure 37)

SITE NAME OR SITE NUMBER: Redwine (41SM193)

VESSEL NO.: Burial 1

NON-PLASTICS: grog

VESSEL FORM: carinated bowl

RIM AND LIP FORM: direct, flat with Myers mode rim, 21 sprockets evenly spaced around the top. In this example, the rim is not so much rolled out as it is thickened to form the cogs of the sprocket. Also, the backside of the cogs is more abrupt, appearing to have been cut with some instrument before the final firing took place. There are other examples of ceramics appearing to have been cut with some instrument prior to firing, such as certain pipes from the Tom Jones site (3HE40) in Arkansas.

CORE COLOR: F, fired in reduced oxygen environment, and cooled in open air

INTERIOR SURFACE COLOR: 7.5YR4/1 (dark gray)

EXTERIOR SURFACE COLOR: 7.5YR5/3 (brown)

WALL THICKNESS (RIM, BODY, AND BASE IN MM): rim, 10.2; body, 7.6; base, 9.0

INTERIOR SURFACE TREATMENT: burnished

EXTERIOR SURFACE TREATMENT: smoothed

HEIGHT: $10.3 \mathrm{~cm}$

ORIFICE DIAMETER: $32.0 \mathrm{~cm}$

DIAMETER AT BOTTOM OF RIM OR NECK: $28.0 \mathrm{~cm}$

BASE DIAMETER: $13.5 \mathrm{~cm}$

DECORATION: incised-punctated freestanding scrolls. There are rows of tool punctates under the lip and at carination point.

TYPE: cf. Washington Square Paneled

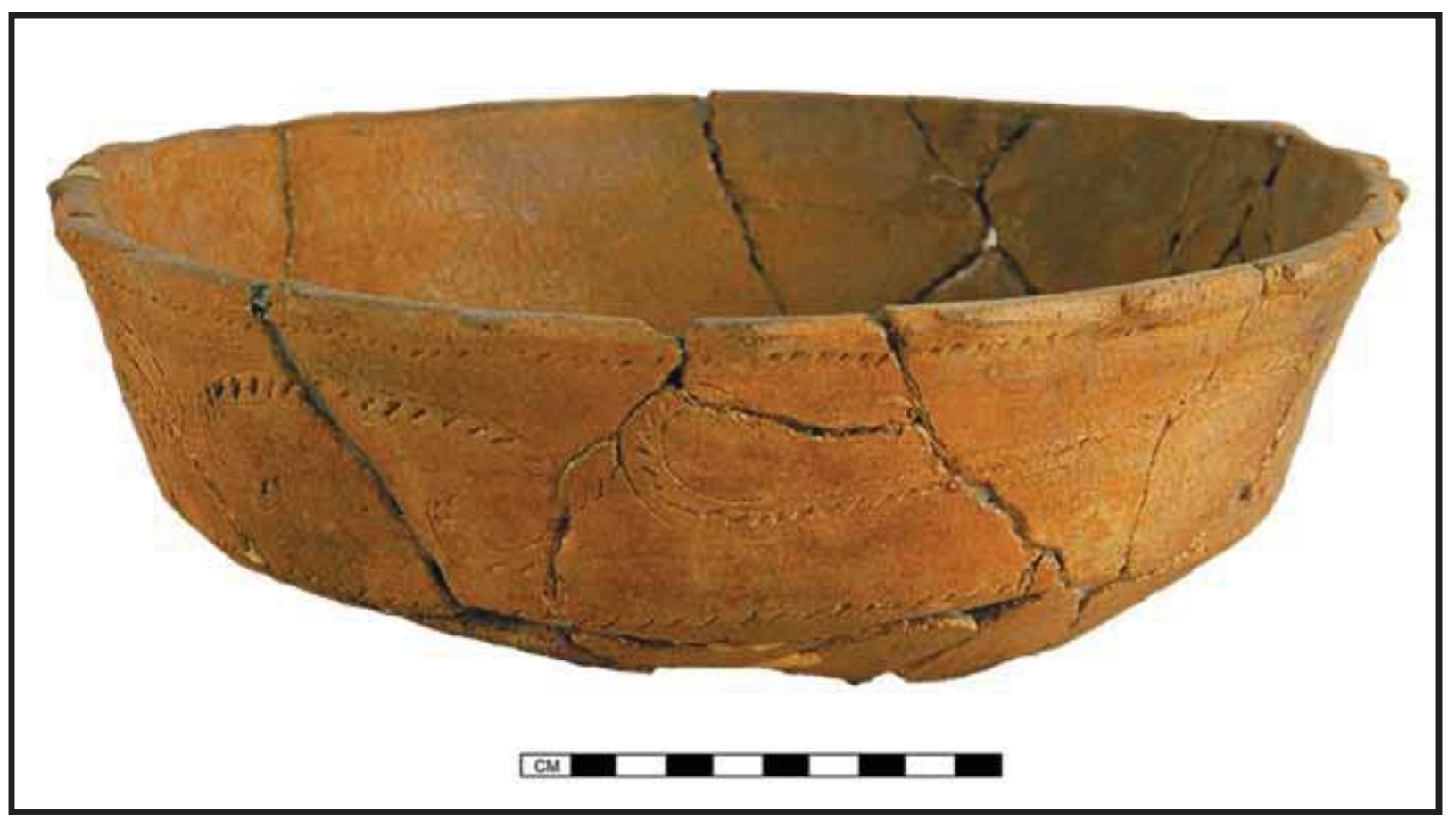

Figure 37. Washington Square Paneled bowl with Myers mode rim, the Redwine site. 


\section{Buddy Calvin Jones Collection}

There are two vessels with Myers mode rims in the Buddy Calvin Jones Collection presently located at the Gregg County Historical Museum in Longview, Texas. One is from the Henry Spencer site in the Little Cypress Creek basin.

\section{Henry Spencer site (41UR315)}

SITE NAME OR SITE NUMBER: Henry Spencer site (41UR315), Gregg County 2008-08-978 (Figure 38a-b)

VESSEL NO.: Burial 10 NON-PLASTICS: grog VESSEL FORM: carinated bowl

RIM AND LIP FORM: direct rim and rounded lip with Myers mode rim with eight sprockets.

CORE COLOR: F, fired in reduced oxygen environment, then cooled in open air

INTERIOR SURFACE COLOR: 10YR5/2 (grayish-brown)

EXTERIOR SURFACE COLOR: 10YR3/2 (very dark grayish-brown)

WALL THICKNESS (RIM, BODY, AND BASE IN MM): Undetermined

INTERIOR SURFACE TREATMENT: smoothed EXTERIOR SURFACE TREATMENT: smoothed

HEIGHT: $6.0 \mathrm{~cm}$ ORIFICE DIAMETER: $17.2 \mathrm{~cm}$

DIAMETER AT BOTTOM OF RIM OR NECK: $15.5 \mathrm{~cm} \quad$ BASE DIAMETER: $7 \mathrm{~cm}$

DECORATION: engraved curvilinear scroll motif repeated four times around body, and a red clay pigment has been rubbed in the lines

TYPE: undetermined
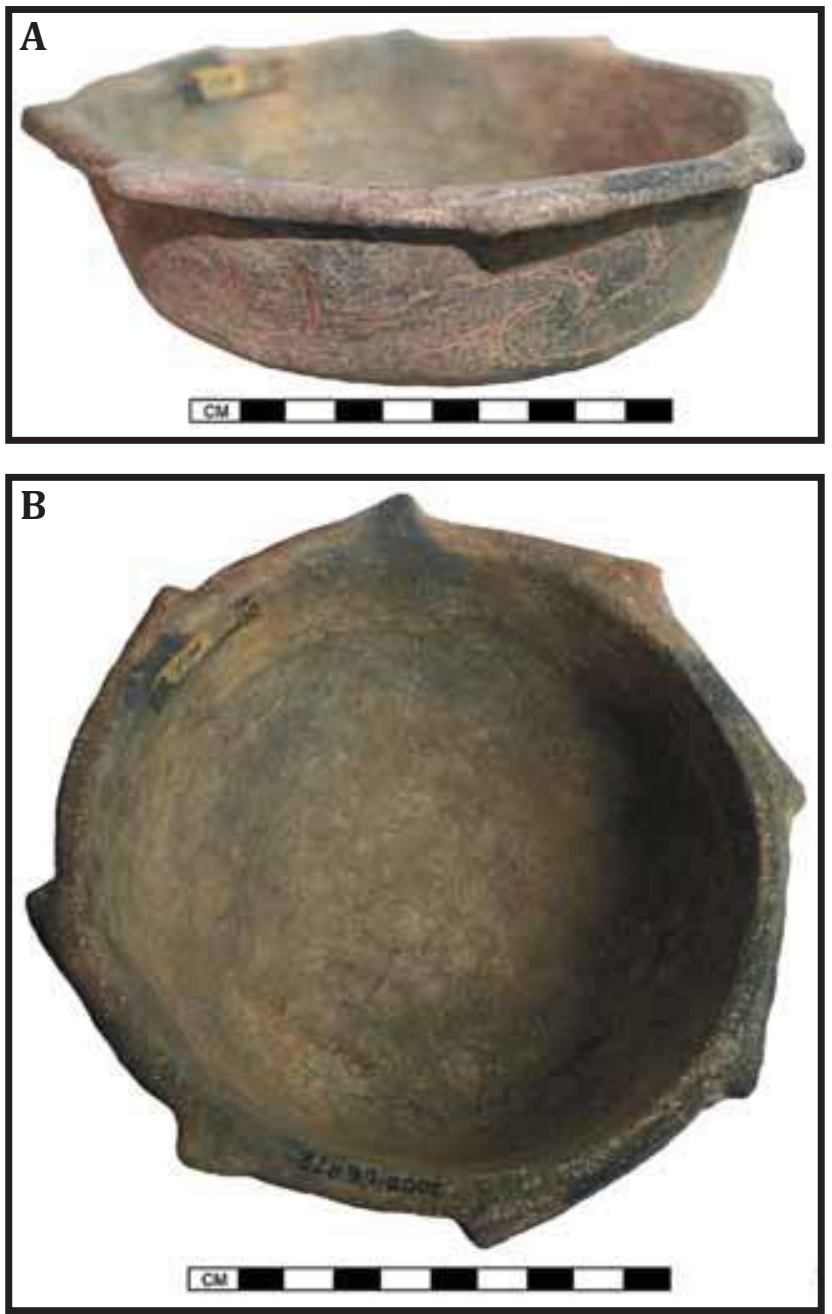

Figure 38. Engraved carinated bowl with Myers mode rim from the Henry Spencer site: a, side view; b, top view. 
The second Myers mode vessel in the Jones collection lacks information about its site provenience or the vessel's association with other artifacts.

SITE NAME OR SITE NUMBER: Undetermined

VESSEL NO.: Gregg County 2003-08-1017 (Figure 39)

NON-PLASTICS: grog

VESSEL FORM: carinated bowl (partial vessel)

RIM AND LIP FORM: direct rim and a rounded, exterior folded lip with Myers mode rim

CORE COLOR: $F$, fired in reduced oxygen environment, cooled in the open air

INTERIOR SURFACE COLOR: 5YR5/3 (reddish-brown)

EXTERIOR SURFACE COLOR: 5YR5/3 (reddish-brown)

WALL THICKNESS (RIM, BODY, AND BASE IN MM): rim, $6.8 \mathrm{~cm}$, body, $6.5 \mathrm{~cm}$

INTERIOR SURFACE TREATMENT: smoothed

EXTERIOR SURFACE TREATMENT: smoothed

HEIGHT: undetermined

ORIFICE DIAMETER: undetermined

DIAMETER AT BOTTOM OF RIM OR NECK: undetermined

BASE DIAMETER: undetermined

DECORATION: engraved curvilinear scroll repeated four times around the vessel rim, with red pigment in the engraved lines

TYPE: undetermined

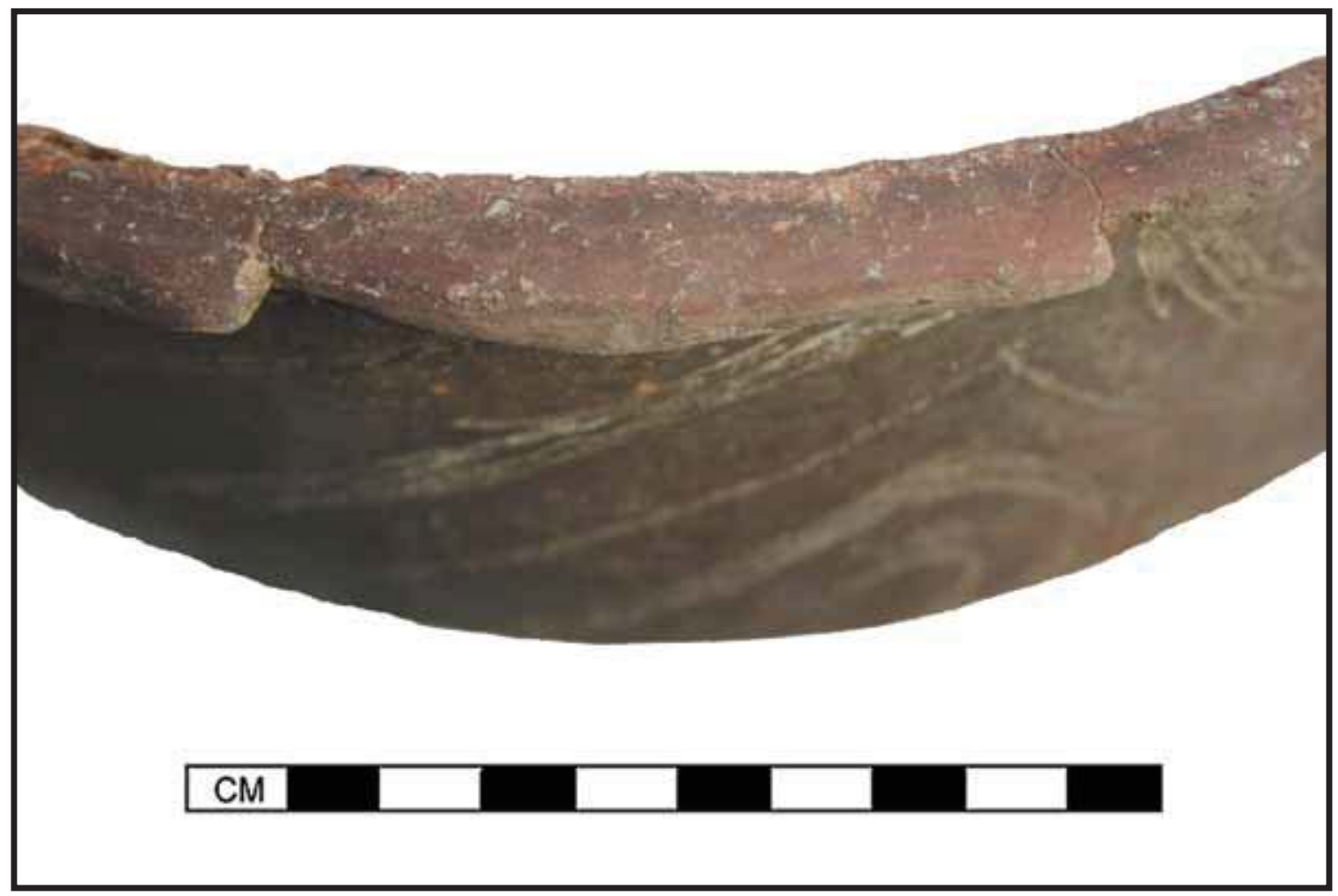

Figure 39. Close-up view of Myers mode rim with cut-edge from a vessel in the Buddy Calvin Jones Collection. 


\section{Buddy Hancock site (41SY45)}

The last known location of a Myers mode vessel in East Texas is from a burial at the Buddy Hancock site (Figure 40). This is the only vessel known from Shelby County featuring a Myers mode sprocket rim treatment.

VESSEL NO.: Burial 1

NON-PLASTICS: coarse bone and grog

VESSEL FORM: Carinated bowl with Myers mode rim, 20 sprockets. Cutting one side of the sprocket apparently shaped the sprockets of this vessel while the vessel was leather hard.

CORE COLOR: F, fired in a reduced oxygen environment, cooled in the open air.

INTERIOR SURFACE COLOR: 10R5/4 (weak red)

EXTERIOR SURFACE COLOR: 5YR4/1 (dark gray); fire clouding

WALL THICKNESS: $\quad 7.1 \mathrm{~mm}$

DISTAL RIM WIDTH: $17.5 \mathrm{~mm}$

INTERIOR SURFACE TREATMENT: smoothed

HEIGHT: $9.0 \mathrm{~cm}$

ORIFICE DIAMETER: $20.0 \mathrm{~cm}$

DISTAL RIM THICKNESS: $5.8 \mathrm{~mm}$

EXTERIOR SURFACE TREATMENT: polished

HEIGHT OF RIM: $3.9 \mathrm{~cm}$

DIAMETER AT BOTTOM OF RIM: $16.5 \mathrm{~cm}$

BASE DIAMETER: $7.6 \mathrm{~cm}$

ESTIMATED VOLUME: 1.61 liters

DECORATION: Four engraved panels of horizontal interlocking scrolls with panel partitions being bi-concave columns or brackets filled with cross-hatching. All engraved lines are filled with white kaolin clay pigment. The central element of the scroll is a horizontal line with two offset hemi-columns (one above and one below the line); the hemi-columns are cross-hatched filled. The remainder of the scroll consists of crook-shaped lines around the ends of the central element. Additional engraved lines are found in a radiating pattern under the sprocket rim treatment.

TYPE: Burr Engraved (Middlebrook n.d.)

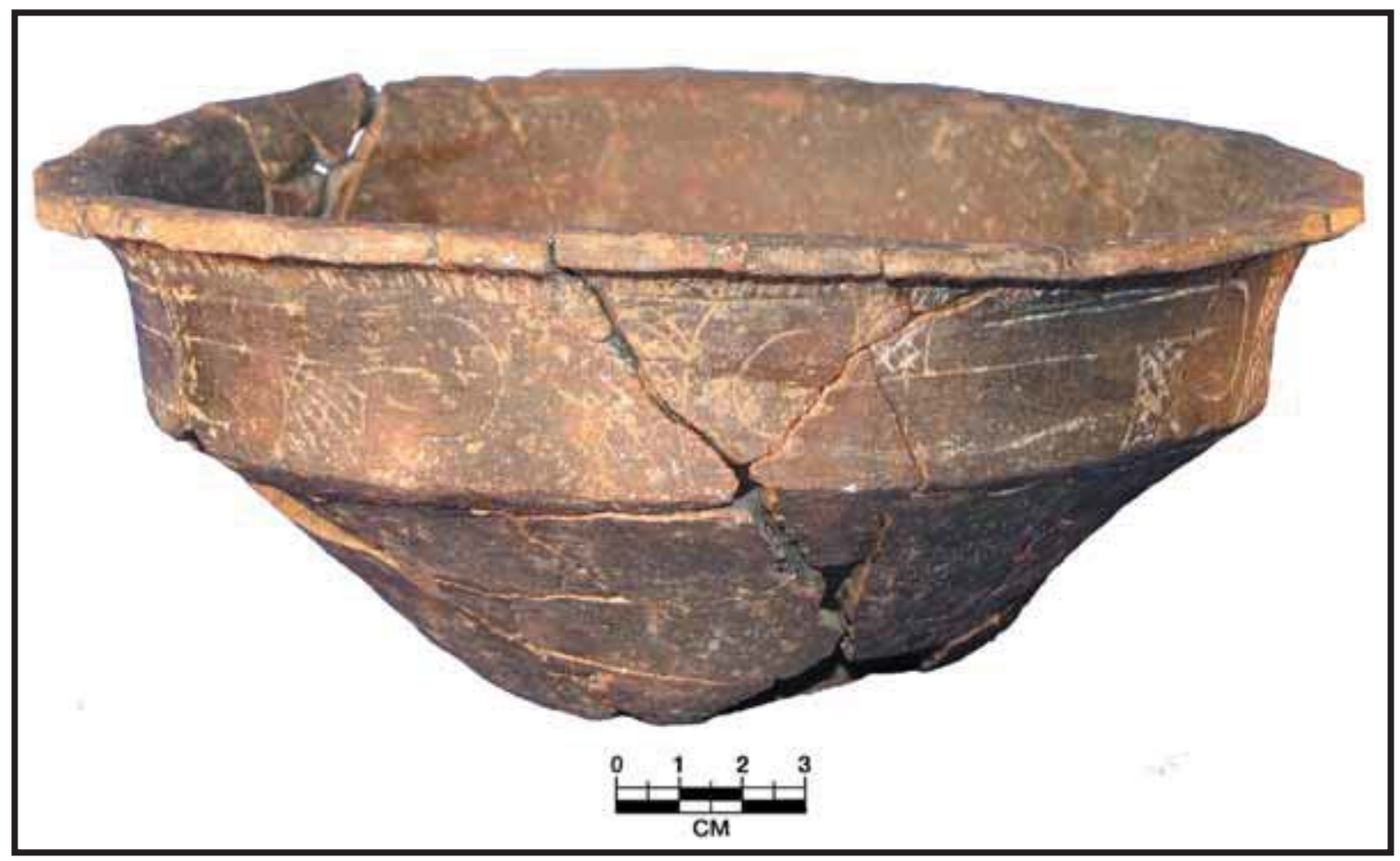

Figure 40. Engraved carinated bowl with Myers mode rim from Buddy Hancock site. 


\section{Summary}

We have defined a new Caddo pottery rim mode (the Redwine or pie crust mode) based on known vessel examples in the published literature and from the examination of various collections. This distinctive rim treatment is found at two Early Caddo mound centers, Bowman and Davis (but with an occupation known to have lasted until ca. A.D. 1300, see Story 2000), and then otherwise almost exclusively on Middle Caddo (A.D. 1200-1400) period vessels in East Texas.

The Redwine mode of rim construction is unique in Caddo pottery. Rims that are at abrupt right angles to the vessel wall and have evenly spaced scalloped lobes are the defining traits, though we have noted some subtle variations of the Redwine mode rim form:

1. At the Redwine Site and neighboring 41SM196, the Redwine mode appears on bowls that are marked by rims that are articulated at right angles and the upper vessel wall is thickened for support. The flattened lobes are more massive than other Redwine mode examples and often have engraved elements on top of the flattened lobes.

2. Also present at Redwine and other sites, including 41SM325, 41SM198, 41SM223, 41HS718, 41RK276, 41UR315, and G.C. 108, there is a second form of rim mode, usually found on carinated bowls having Washington Square Paneled designs. The rims are at right angle to the vessel wall but not thickened to the degree as example one from Redwine. No instances are known of there being decorations on top of the lobes but there is often decoration (i.e., incised lines or a row of punctates) on the underside of the lobes.

The remainder of the Redwine mode examples are from bowls with rims shaped like the second form and decorated with various Middle Caddo engraved elements, (plus other elements including punctuates and brushing) with strap handles, and black burnished or polished surfaces, excepting one plain vessel from the Lang Pasture site.

The origins of the Redwine rim mode are not clear. However, the numerous Redwine mode rims examples at the Bowman site on the Red River and the George C. Davis site in East Texas may point to the origin(s) of the Redwine mode. Since the Davis site was occupied from ca. A.D. 850-1300 (Story 2000), and the Bowman site may have also had a long occupation beyond its major Early Caddo component, it is presently unclear if the Redwine mode vessels at either site occur in contexts that pre-date A.D. 1200. If that were the case it would obviously suggest the temporal origin of the Redwine mode rim; it further could indicate close ties between these two important Caddo sites.

Following a putative pre-A.D. 1200 origin, there was a florescence of this rim mode style during the Middle Caddo period in certain distinct areas, particularly in East Texas (see Figure 4). The tracing of this mode through space and time could show the dispersal and range of the people who once inhabited the Davis site, if George C. Davis or a site in its vicinity was where this style was first developed. The presence of Redwine mode rims at the Washington Square Mound site shows a continuation of this style. The Washington Square Mound site is thought to be a later manifestation of the Davis site (Hart 1982:135-138), or at least that it began to flourish about the same time that the George C. Davis site was losing power and social authority among East Texas Caddo groups (Perttula 2009:190), The known examples of Washington Square Paneled and Nacogdoches Engraved at Redwine point to a strong connection between the Washington Square Mound and Redwine sites, which are located about 75 miles apart. There are also certain elements in the Redwine mortuary offerings-such as Haley Engraved design elements and the presence of Red River, var. Haley pipes (Walters and Haskins 1998:Figure 15c) — that point to connections with Caddo groups on the Red River, such as at the Haley site (3M11), which is about 100 miles northeast of Redwine. Another possible East Texas-Haley 
phase connection at Redwine was a possible Haley Complicated-Incised jar (Walters and Haskins 1998:Figure 11g), but this could have also been a variant of Reavely Brushed-Incised (Hart 1982), a local Washington Square Mound ceramic type.

Although there does not seem to have been many vessels with Redwine mode rims, its use seems to have reached its greatest popularity in Middle Caddo times, a time when Caddo populations seemed to be at their greatest numbers and artistic expression in ceramic vessels at its greatest level. After A.D. 1400, Caddo populations seemed to have diminished in some regions, even to the point of abandonment of much of what is now Smith County, Texas. In addition, after this time in East Texas sites, there is a noticeable decrease in the variety of stylistic motifs and decorative elements on Caddo ceramics. Whether these changes were the result of significant climate changes, social upheavals, or simply changes in ways of doing things, is unknown at the present time, but the further study of the Redwine mode, as well as the Myers mode, may be a way to help determine what happened at the end of the Middle Caddo period, and how those changes affected Caddo ceramic styles.

Did the Redwine mode or Myers mode vessels originate from one source or did different Caddo groups copy or produce their own version of what they thought such vessels should look like? The current evidence suggests the latter is the more likely possibility. Although similar in some ways, the Redwine mode rim vessels are distinctly different from the Meyer's mode rims, not the least of which is that the latter rim treatment occurs primarily on Caddo sites in southwestern Arkansas. Certainly the concept of the Redwine mode was a local innovation that gained wider acceptance through time and space, but by what avenue? Instrumental neutron activation analysis of these vessels may shed light on the ultimate provenience of these vessels, and determine if they were made in one, a few, or multiple locales across the Caddo area. There are examples of this form in earlier Alto phase contexts, after which the rim mode idea became more popular in the Middle Caddo period, only to fall from usage in later Caddo times. The combination of vessels with Redwine mode rims and designs such as Washington Square Paneled and Nacogdoches Engraved point to connections between Caddo groups south and west of the Sabine River and other groups living to the south in the Angelina River drainage. The Redwine mode is noticeably absent north and east of the Sabine River, suggesting limited contact with Caddo groups in those areas, the existence of different ceramic traditions, or at least differences in ideas/beliefs as they were portrayed through their pottery.

\section{Acknowledgments}

I would like to give thanks to Tom Middlebrook and Tim Perttula for their contributions to this article. I would especially like to thank Tim Perttula for his unselfish time and effort in editing the manuscript. John Miller, author of the Myers Mound report, provided crucial information regarding his analysis of the artifacts from that site. I would also like to thank Dr. Ann Early for her helpful comments. Dr. Jamie Brandon of Southern Arkansas University at Magnolia provided me with photographs of the Bowman Collection. 


\section{References Cited}

Bohannon, C. F.

1973 Excavations at the Mineral Springs Site, Howard County, Arkansas. Research Series No. 5. Arkansas Archeological Survey, Fayetteville.

Bonds, J. W.

2006 Art of the Ancient Caddo. Grove Hill Publishing, Leonard, Texas.

Early, A. M.

1988 Standridge: Caddoan Settlement in a Mountain Environment. Research Series No. 29. Arkansas Archeological Survey, Fayetteville.

Gadus, E. F., R. C. Fields, J. K. McWilliams, J. Dockall, and M. C. Wilder

2006 National Register Testing of Seven Prehistoric Sites in the Sabine Mine's Area Q, Harrison County, Texas. Reports of Investigations No. 147. Prewitt \& Associates, Inc., Austin.

Gonzalez, B., R. Cast, T. K. Perttula, and B. Nelson

2005 A Rediscovering of Caddo Heritage: The W. T. Scott Collection at the American Museum of Natural History and Other Caddo Collections from Arkansas and Louisiana. Historic Preservation Program, Caddo Nation of Oklahoma, Binger, Oklahoma.

Harrington, M. R.

1920 Certain Caddo Sites in Arkansas. Indian Notes and Monographs, Miscellaneous Series 10. Museum of the American Indian, Heye Foundation, New York.

Hart, J. P.

1982 An Analysis of the Aboriginal Ceramics from the Washington Square Mound Site, Nacogdoches County, Texas. Master's thesis, Department of Anthropology, Northeast Louisiana University, Monroe.

Middlebrook, T.

1993 Radiocarbon Dates from the Tyson Site (41SY92). Caddoan Archeology Newsletter III(4):2-8.

n.d. Unpublished manuscript on the Burr site.

Miller, J. E., III

1986 The Myers Mound: Salvage Excavations at a Caddo II Site in Southwest Arkansas. The Arkansas Archeologist 23/24:67-127.

Moore, C. B.

1912 Some Aboriginal Sites on Red River. Journal of the Academy of Natural Sciences of Philadelphia 14:481-644.

Newell, H. P. and A. D. Krieger

1949 The George C. Davis Site, Cherokee County, Texas. Memoirs No. 5. Society for American Archaeology, Menasha, Wisconsin 


\section{References Cited (Cont.)}

Perino, G.

1994 The Rowland Clark (41RR77) Site, Red River County, Texas. Journal of Northeast Texas Archaeology $4: 3-60$.

Perttula, T. K., with contributions by D. E. Wilson and M. Walters

2006 A Study of the Buddy Calvin Jones Collection From Northeast Texas Caddo Sites. Special Publication No. 6. Friends of Northeast Texas Archaeology, Pittsburg and Austin.

Perttula, T. K., with contributions by B. Nelson and M. Walters

2009 Caddo Ceramic and Lithic Artifacts from the Washington Square Mound Site (41NA49) in Nacogdoches County, Texas: 1985 Texas Archeological Society Field School Investigations. Bulletin of the Texas Archeological Society 80:145-193.

Perttula, T. K. (editor)

2008 Lake Naconiche Archeology, Nacogdoches County, Texas: Results of the Data Recovery Excavations at Five Prehistoric Archeological Sites. 2 Vols. Report of Investigations No. 60. Archeological \& Environmental Consultants, LLC, Austin.

Perttula, T. K., M. Walters, B. Nelson, and R. Cast

2009a Documentation of Associated and Unassociated Caddo Funerary Objects in the Stephen F. Austin State University Collections, Nacogdoches, Texas. Historic Preservation Program, Caddo Nation of Oklahoma, Binger, Oklahoma.

Perttula, T. K., M. Walters, and B. Nelson

2009b Documentation of the Native American Ceramic Vessels From Northeast Texas, Southern Arkansas, and Eastern Oklahoma in the Boyce Smith Museum in Troup, Texas. Special Publication No. 8. Friends of Northeast Texas Archaeology, Pittsburg and Austin.

Rice, P.M.

1987 Pottery Analysis: A Sourcebook. University of Chicago Press, Chicago.

Rogers, R. and T. K. Perttula

2004 The Oak Hill Village Site (41RK214), Rusk County, Texas. Document No. 030083. PBS\&J, Austin.

Rouse, I.

1971 The Classification of Artifacts in Archeology. In Man's Imprint From the Past, edited by J. Deetz, pp. 108-125. Little, Brown, and Company, Boston.

Sherman, D. L., T. K. Perttula, S. S. Victor, and M. A. Nash

2001 NRHP Eligibility Testing (41RK107, 41RK240, 41RK242, 41RK243, 41RK276, and 41RK286) and Additional Testing (41RK243) Investigations within the Oak Hill DIII Mine, Permit No. 46, Rusk County, Texas. Document No. 00237. PBS\&J, Austin.

Story, D. A.

2000 Introduction. In The George C. Davis Site, Cherokee County, Texas, by H.P. Newell and A. D. Krieger pp. 1-31. $2^{\text {nd }}$ Edition. Society for American Archaeology, Washington, D.C. 


\section{References Cited (Cont.)}

Suhm, D. A. and E. B. Jelks (editors)

1962 Handbook of Texas Archeology: Type Descriptions. Special Publication No. 1, Texas Archeological Society, and Bulletin No. 4, Texas Memorial Museum, Austin.

Walters, M.

2006 The Lake Clear Site (41SM243) and Crotalus horridus atricaudatus. Caddo Archeology Journal 15:5-40.

Walters, M. with contributions from L. G. Cecil, L. S. Cummings, J. P. Dering, J. R. Ferguson, M. D. Glascock, T. K. Perttula, L. Schniebs, H. J. Shafer, J. Todd, and C. P. Walker

2008 Life on Jackson Creek, Smith County, Texas: Archeological Investigations of a $14^{\mathrm{TH}}$ Century Caddo Domicile at the Leaning Rock Site (41SM325). Caddo Archeology Journal 17:1-114.

Walters, M. and P. Haskins, with contributions by D. H. Jurney, S. E. Goldborer, and T. K. Perttula 1998 Archaeological Investigations at the Redwine Site (41SM193), Smith County, Texas. Journal of Northeast Texas Archaeology 11:1-38.

White, Leslie

1959 The Evolution of Culture. McGraw-Hill, New York. 